\title{
Show and Tell, Seek and Find: A Balanced Approach to Defining a Fourth Amendment Search and the Lessons of Rape Reform
}

\author{
Nadia B. Soree
}

I. INTRODUCTION

II. FROM 1967 TO 1984 AND BEYOND: DECONSTRUCTING AND

RECONSTRUCTING KATZ

A. Nothing to Hide, Nothing to Fear ... But the Search

Itself.

B. A First Look at Katz: Was It All We Expected? ................ 142

C. A Second Look at Katz: Conduct in the Content............. 150

III. The Evolution of RAPE LAW: We've COME A LONG WAY,

BABY....

A. Rape Law Then: Helpful to Defendants, Hostile to Victims

B. Rape Law Under Siege: The Impetus for Change

C. Rape Law Now: Some Welcome Victories

IV. From RaPe LaW tO SEARCH LAW: A QuANTUM LEAP TO A

PARALLEL UNIVERSE

A. Search Law Then (and Now): Helpful to Law Enforcement, Hostile to Victims ..................................... 185

B. Search Law Under Siege ................................................. 202

C. Search Law Tomorrow: What We Can Learn from Rape Reform ................................................................. 209

1. Abolishing the Utmost Resistance Requirement ....... 209

2. Recalibrating Force and Nonconsent ........................ 213

3. A Balanced Approach to the Katz ReasonableExpectation-of-Privacy Test

"J.D., Yale Law School, Assistant Professor, St. Thomas University School of Law. I wish to thank Thomas Clancy, Sherry Colb, Alfredo Garcia, Lauren Gilbert, Ellen Podgor, and Amy Ronner for their comments on an earlier draft. While I benefitted tremendously from their wisdom and insights, I take complete ownership of the remaining flaws. I also wish to express my gratitude to Ira Nathenson for his invaluable advice and assistance with this project. For their excellent research assistance, I thank Kerry Nierenberg, Melodee Rhodes, Florence Rubio, and Sherlyn Selassie. 
A rapist not only violates a victim's privacy and personal integrity, but inevitably causes serious psychological as well as physical harm in the process. The long-range effect upon the victim's life and health is likely to be irreparable; it is impossible to measure the harm which results. . . Rape is not a mere physical attack -it is destructive of the human personality.

-Chief Justice Burger ${ }^{1}$

Among deprivations of rights, none is so effective in cowing a population, crushing the spirit of the individual and putting terror in every heart.... [T] he human personality deteriorates and dignity and self-reliance disappear where homes, persons and possessions are subject at any hour to unheralded search and seizure by the police.

$$
\text { -Justice Jackson }{ }^{2}
$$

\section{INTRODUCTION}

I begin by echoing Chief Justice Burger's conviction that the profound harm suffered by the victim of a rape is immeasurable and can be compared with few other violations of the human body, personality, and spirit in its scope and magnitude. Without trivializing or diminishing the gravity of the injury imposed upon victims of rape, or making any comparison in degree, I also share Justice Jackson's sentiment, expressed above, that the victims of Fourth Amendment violations, whether through physical intrusions of home, body, or effects, or through other more intangible assaults on liberty, privacy, and dignity, also suffer significant harm. At a basic conceptual level, in each context, one entity asserts a claim of power over another, using that power to extract from the victim that which it seeks to obtain.

This Article seeks to explore and develop a theoretical relationship between rape law and Fourth Amendment search doctrine in order to apply, by way of analogy, the insights and lessons of the rape reform movement to the task of promoting a broader,

\footnotetext{
1 Coker v. Georgia, 433 U.S. 584, 611-12 (1977) (Burger, C.J., dissenting).

2 Brinegar v. United States, 338 U.S. 160, 180-81 (1949) (Jackson, J., dissenting).
} 
more inclusive definition of the Fourth Amendment search. ${ }^{3}$ The Article argues that the Court, in crafting its search doctrine, has created a regime favoring law enforcement at the expense of individual privacy and autonomy, much as traditional rape law was well-disposed towards alleged perpetrators at the expense of victims.

At the outset of this Article, I wish to note my choice of the word "victim" to connote one who has endured a rape as well as one who has been the target of unlawful government surveillance. In the rape context, I am aware of the debate surrounding the use of this label, perhaps because the word "victim" is imbued with an aura of passivity or helpless vulnerability, and perhaps because there is still some residual shame (and blame) associated with victimhood in the sexual abuse context. ${ }^{4}$ On the other hand, while some may find the use of the word "victim" offensive in the search context-after all, it may be hard for some to imagine many criminal defendants as victims (especially those factually guilty defendants seeking to suppress the evidence of their unlawful behavior uncovered by the surveillance $)^{5}-$

${ }^{3}$ At least one other scholar has also recognized the benefit of turning to rape law to inform consent doctrine in the Fourth Amendment realm. See Josephine Ross, Blaming the Victim: 'Consent' Within the Fourth Amendment and Rape Law, 26 HARV. J. ON RACIAL \& ETHNiC JUST. 1 (2010) (identifying the parallels between rape law and Fourth Amendment consent doctrine and arguing that feminist theory should be imported into Fourth Amendment law in order to promote a more realistic conception of consent that takes into account the imbalance of power between police and citizens, that does not equate consent with submission to authority, and that focuses on individual autonomy). I would like to emphasize that, while I seek to draw parallels between these two areas of law in the abstract, I am in no way equating the atrocity of the crime of rape, or the devastation suffered by those who have experienced this heinous crime, to government surveillance and the impact of such surveillance on its subjects, and I am aware, of course, that the law of rape is a matter of substantive criminal law, while the law of searches is a matter of criminal procedure. Further, I also acknowledge the legitimate law enforcement purposes of government surveillance in the interests of detecting and preventing crime, which, of course, has no parallel in the discussion of rape. Nonetheless, in constructing a framework for substantively defining the Fourth Amendment search, I look to the law of rape, in both its substantive and procedural aspects, for guidance.

${ }^{4}$ Sharon Lamb, Constructing the Victim: Popular Images and Lasting Labels, in NEW Versions of Victims: Feminists Struggle With the ConCEPT 108, 118-19 (Sharon Lamb ed., 1999) ("[T] he term survivor evokes ... heroic adaptation. The new label was the first suggestion that the victim was an active resister in her abuse, and that whatever she did ... she did this to 'survive.' ... Why did victims resist being called 'victims'? It is shameful to be a victim in our culture. No matter how much victims' rights advocates and therapists have told victims that they are not to blame for their abuse, that they did not provoke it, and that it had nothing to do with them, it is still shameful to be a victim.").

5 Ross, supra note 3 , at 10 ("The public tends to view the victims of police searches as unworthy of the "victim" label because they were caught with drugs or 
this is precisely the term used to describe those claiming an unlawful search. ${ }^{6}$ For clarity and ease of description, as well as to engage the analogy between these areas of law, I will use the term "victim" in both contexts.

I was led to this analogy between the law of rape and the law defining searches, which is the focus of this Article, by my examination of, and dissatisfaction with, current Fourth Amendment standing doctrine. ${ }^{7}$ In Rakas $v$. Illinois, the first in a set of three cases that established the Supreme Court's approach to standing, the Court held that a defendant may seek suppression of evidence discovered through an allegedly unlawful search only if she has a "legitimate expectation of privacy in the particular areas" searched. ${ }^{8}$

other contraband. This article aims to do for victims of searches what feminists have done for victims of unwanted sexual touching. Certainly there are differences between rape and police searches ... but these differences do not require the law to treat like elements as unalike."). Professor Ross seeks to help "humanize the victims of nonconsensual search and seizures" and encourages her readers to "grapple with the antipathy they might normally accord to victims of Fourth Amendment violations and consider how this response skews logic and fairness." Id.

See, e.g., United States v. Calandra, 414 U.S. 338, 350-51 (1974) (“[T]his Court declined to extend the exclusionary rule to one who was not the victim of the unlawful search."); Jones v. United States, 362 U.S. 257, 261 (1960) ("In order to qualify as a 'person aggrieved by an unlawful search and seizure' one must have been a victim of a search or seizure.").

7 See Nadia Soree, The Demise of Fourth Amendment Standing: From Standing Room to Center Orchestra, 8 NEV. L.J. 570 (2008) (providing analysis and critique of current Fourth Amendment standing doctrine).

8439 U.S. 128, 148 (1978). In reaching its holding, Rakas repudiated the "legitimately on the premises" test of standing announced in Jones $v$. United States, 362 U.S. 257 (1960). Rakas, 439 U.S. at 142. In announcing the legitimate expectation of privacy test as the proper test of standing, the Court also disapproved of the concept of standing as a separate procedural inquiry, merging the standing inquiry with the merits of the suppression hearing: "But we think the better analysis forthrightly focuses on the extent of a particular defendant's rights under the Fourth Amendment, rather than on any theoretically separate, but invariably intertwined concept of standing." Id. at 139. I will continue to use the term "standing" to refer to the ability of a given defendant to seek suppression of evidence, as a matter independent from the ultimate resolution of the suppression hearing. Although the Rakas opinion left open the possibility of a defendant's ability to seek suppression on the basis of a property or possessory interest in the item seized, the Court's opinions in Rawlings v. Kentucky, 448 U.S. 98 (1980), and United States v. Salvucci, 448 U.S. 83 (1980), left no doubt that even such an interest in the item seized does not suffice to permit a defendant the opportunity to press a Fourth Amendment claim based on an allegedly unlawful search. Rakas, 439 U.S. at 137 n.6. In Rawlings, although the defendant admitted ownership, for suppression purposes, of the drugs found in his companion's purse, the Court denied him "standing" to challenge the search because he had no legitimate expectation of privacy in the purse. Rawlings, 448 U.S. at 105-06. Thus, the police conduct in searching the purse was simply never examined at all. 
In other words, the Court adopted, although not entirely accurately, the substantive test used to define a Fourth Amendment search, derived from Katz $v$. United States, ${ }^{9}$ as the proper measure of a defendant's ability to challenge the government activity that unearthed the evidence to be used against her at trial. ${ }^{10}$ In Rakas, the Court used this test to preclude the defendants from challenging the search of an automobile that produced evidence against them because "they made no showing that they had any legitimate expectation of privacy in the glove compartment or area under the seat of the car in which they were merely passengers."11 Therefore, because Rakas, a mere passenger, had no legitimate expectation of privacy in these particular areas of the car, ${ }^{12}$ the Court never had to address whether the police acted in accordance with the Fourth Amendment. ${ }^{13}$

What I believe to be the most troubling consequence of the decision to subsume standing under the substantive definition of a search is that, even when the government is clearly acting improperly, such misconduct receives no judicial scrutiny - a perverse outcome if one conceives of the Fourth Amendment as a provision meant to regulate the government's use of power against its citizens. ${ }^{14}$ It should be no surprise, then, that what I argue is the most troubling

9389 U.S. 347 (1967).

10 In adopting this test, the Court in Rakas, citing Katz at page 353, stated, "the Court in Katz held that capacity to claim the protection of the Fourth Amendment depends not upon a property right in the invaded place but upon whether the person who claims the protection of the Amendment has a legitimate expectation of privacy in the invaded place." Rakas, 439 U.S. at 143. However, a thorough exploration of the cited page in Katz fails to reveal either the word "expectation" or “place." Katz, 389 U.S. at 353.

11 Rakas, 439 U.S. at 148.

12 Justice White, in dissent, wonders what, short of ownership, would have satisfied the Court to establish the requisite expectation of privacy. Id. at 165 (White, J., dissenting).

13 See Rakas, 439 U.S. at 130; see also Soree, supra note 7, at 621 (explaining that the Rakas majority made no pretense of concern with whether there was, in fact, the proper level of justification for the search at issue, stating at the outset of the discussion that a brief exposition of the facts was adequate because "we are not here concerned with the issue of probable cause." (quoting Rakas, 439 U.S. at 130)).

${ }^{14}$ One need not look any further than United States v. Payner, 447 U.S. 727 (1980), for evidence that the Court's standing doctrine permits, perhaps even encourages, the government's lawless behavior in investigating crime. In Payner, government agents broke into and retrieved documents from a banker's briefcase, knowing that third parties would not have "standing" to claim a Fourth Amendment violation with respect to the briefcase and thus, the evidence gained from an obviously unlawful search would be (and was) admissible against Payner, who was convicted of falsifying his income tax return. See id. at 728-32. 
flaw of current standing doctrine-that courts may, even must, ${ }^{15}$ turn a blind eye to governmental misconduct-is also to a significant extent a characteristic of the test used to define a search, at least as currently applied. Although I have elsewhere argued that the Court should once again separate standing from the substantive definition of a search, ${ }^{16}$ assuming the status quo, the reasonable-expectation-ofprivacy test should be reconceived to include a more meaningful examination of the government's conduct in seeking information.

Recently, the Court has indicated its willingness to reexamine and reevaluate its post-Katz search doctrine. On January 23, 2012, the Court, in holding that the Government's placement of a Global Positioning System (GPS) on defendant's vehicle and the use of the GPS to monitor his movements over a period of four weeks constituted a Fourth Amendment search, announced that "Jones's Fourth Amendment rights do not rise or fall with the Katz formulation." ${ }^{17}$ The Court framed its decision fairly narrowly, restricting its holding to the fact that the Government, for the purpose of gaining information, "physically intrud[ed] on a constitutionally protected area," 18 leaving open whether such long-

15 The Court in Payner held that a federal court was not permitted to exclude evidence pursuant to its supervisory powers, even in the face of "the Government's knowing and purposeful bad faith hostility to any person's fundamental constitutional rights." Id. at 730-31 (internal citations omitted).

${ }_{16}$ See Soree, supra note 7, at 620.

17 United States v. Jones, 132 S. Ct. 945,947 (2012).

18 Id. at 950 n.3. The Court found it unnecessary to ascertain whether Mr. Jones had a reasonable expectation of privacy in his movements, reasoning that "Katz did not erode the principle 'that, when the Government does engage in physical intrusion of a constitutionally protected area in order to obtain information, that intrusion may constitute a violation of the Fourth Amendment."' $I d$. at 951. Justice Scalia, writing for the Court, stated his judgment that the Fourth Amendment must be interpreted to "provide at a minimum the degree of protection it afforded when it was adopted," hinting that the application of the Katz formulation to these facts might have mandated the opposite result. Id. at 953 ("The concurrence does not share that belief. It would apply exclusively Katz's reasonable-expectation-of-privacy test, even when that eliminates rights that previously existed."). Justices Sotomayor and Alito, in their respective concurring opinions, however, indicated their belief that such long-term GPS monitoring would indeed impinge upon reasonable expectations of privacy, although Justice Sotomayor found it unnecessary to reach that question in this case. Id. at 955, 957 (Sotomayor, J., concurring) ("When the Government physically invades personal property to gather information, a search occurs. The reaffirmation of that principle suffices to decide this case."); Id. at 964 (Alito, J., concurring) ("But the use of longer term GPS monitoring in investigations of most offenses impinges on expectations of privacy.... We need not identify with precision the point at which the tracking of this vehicle became a search, for the line was surely crossed before the 4-week mark."). 
term surveillance accomplished without physical intrusion would constitute a search under the Katz formulation. ${ }^{19}$ The Court indicated, though, that "the Katz reasonable-expectation-of-privacy test has been added to, but not substituted for, the common-law trespassory test." ${ }^{20}$ Further, in her concurring opinion, Justice Sotomayor, while agreeing with the trespass-based reasoning of the Court under the particular facts of the case, urged that it may be "necessary" to reconsider the Court's existing post-Katz jurisprudence. $^{21}$ Additionally, Justice Alito, in his concurrence, although not embracing the trespass rationale and, instead, adhering to the reasonable-expectation-of-privacy test, noted that this test "is not without its own difficulties." 22

What is clear, after Jones, is that absent a trespass on a constitutionally protected area (for the purpose of gathering information), ${ }^{23}$ the Katz reasonable-expectation-of-privacy test still controls the threshold question of whether a Fourth Amendment search has occurred, ${ }^{24}$ and is therefore the subject of this Article's efforts to induce much needed reform. What is equally clear is that the law of searches is in flux, and that the Court has recognized the inability of $\mathrm{Katz}$, in its application to this point, to adequately protect the public against modern-day encroachments on privacy. The time is ripe for the development of Fourth Amendment search doctrine, and the law of rape provides a rich source of grist for the mill of change.

The primary goal of this Article, then, is to propose a more balanced approach to defining Fourth Amendment searches that takes into account the conduct of both law enforcement and the

19 Jones, 132 S. Ct. at 954 ("It may be that achieving the same result through electronic means, without an accompanying trespass, is an unconstitutional invasion of privacy, but the present case does not require us to answer that question.”).

${ }^{20}$ Id. at 954. See infra Part II.B for a discussion of Katz as departing from a definition of a search that required a governmental trespass (or physical intrusion) into a constitutionally protected area.

${ }^{21}$ Id. at 957 (Sotomayor, J., concurring).

${ }^{22}$ Id. at 962 (Alito, J., concurring).

23 The Court's opinion, interestingly, stressed the Government's purpose of gathering information as a factor in defining the search, $i d$. at $951 \mathrm{n} .5$, as has been urged by Professor Thomas Clancy. See Thomas K. Clancy, What Is a "Search" Within the Meaning of the Fourth Amendment?, 70 ALB. L. REv. 1, 39 (2006). Professor Clancy has also noted that the Court has generally found the Fourth Amendment to apply to physical invasions, even minor ones, which is consistent with the Court's decision in Jones. See Jones, 132 S. Ct. at 949.

${ }_{24}$ Id. at 953 ("Situations involving merely the transmission of electronic signals without trespass would remain subject to Katz analysis."). 
victim of surveillance to determine whether a search has occurred, resulting in a doctrine truer to the letter and spirit of Katz. As this Article will demonstrate, the current application of Katz places almost exclusive scrutiny on the conduct and precautions taken by the victim of the surveillance, and in fact requires unreasonably onerous efforts to maintain privacy, with scant attention given to the measures taken by the government to overcome those precautions. ${ }^{25}$

We can now begin to examine how the law of rape can provide a relevant analogy and useful framework for a new understanding of Fourth Amendment searches. At common law, forcible rape was defined as follows: "carnal knowledge of a woman forcibly and against her will." ${ }^{26}$ While force and nonconsent were both required elements of the crime of rape, ${ }^{27}$ traditionally these elements were defined almost exclusively in terms of the victim's conduct, making the victim's resistance a de facto element of rape. ${ }^{28}$ Further, under the traditional model of rape, not only was resistance required on the part of the victim, but it was necessary for the victim to resist to the utmost in order for the law to recognize what occurred as rape. ${ }^{29}$

Naturally, the requirement of utmost resistance resulted in a definition of rape that punished only the most extreme uses of force, as only severe force used by the perpetrator would be successful in overcoming this mandatory level of resistance, even in the face of the victim's clear nonconsent. This Article argues that current search doctrine suffers from the same defect identified by critics of traditional rape law: as rape was originally defined by the victim's conduct and state of mind, so the Fourth Amendment search is currently defined primarily by the conduct and state of mind of its victim as well. While a rape was not deemed to have occurred absent the actor's use of force sufficient to overcome the utmost resistance of the victim, a search similarly is not deemed to have occurred unless

25 See infra Part III.

264 William Blackstone, Commentaries on the LAWS OF ENGLAND 210 (1769).

27 E.g., Joshua Dressler, Understanding Criminal LAW $§ 33.04$ (5th ed. 2009) [hereinafter DRESSLER, UNDERSTANDING CRIMINAL LAW].

28 See, e.g., Anne M. Coughlin, Sex and Guilt, 84 VA. L. Rev. 1, 16-17 (1998) (setting forth common objections to the traditional approach in rape prosecutions, which "places the victim's behavior and demeanor at the center of the trial"); Susan Estrich, Rape, 95 YALE L.J. 1087, 1094 (1986) (arguing that requirements of force and nonconsent are both determined in reference to the victim's behavior).

${ }^{29}$ E.g., Michelle J. Anderson, Reviving Resistance in Rape Law, 1998 U. ILL. L. Rev. 953, 957 (1998); Estrich, supra note 28, at 1099; Richard Klein, An Analysis of ThirtyFive Years of Rape Reform: A Frustrating Search for Fundamental Fairness, 41 AKRON L. REv. 981, 987 (2008). 
the government is able to overcome what amounts to utmost resistance, measured by the precautions taken to maintain one's integrity against governmental intrusion. ${ }^{30}$

While this Article does not seek to make any normative claims with respect to the reforms achieved in the law of rape,$^{31}$ there are valuable insights to be gained from examining the evolution of rape law, and the concerns animating that evolution, that can illuminate the pursuit of a new paradigm for defining Fourth Amendment searches. Part II discusses Katz and some of its progeny, taking into account the Court's recent decision in United States $v$. Jones, ${ }^{32}$ and briefly sketching the argument that the language and spirit of Katz support the more balanced, conduct-oriented approach that this Article proposes. This section begins, however, by emphasizing the significance of the injury suffered by victims of compelled searches of body or home, and by reasserting the importance of recognizing more than simply the most egregious practices of governmental surveillance as deserving of Fourth Amendment protection. Part III focuses on the law of rape, discussing the primary critiques of traditional rape law and the broader goals sought to be achieved by reformers in this area, as well as the specific reforms developed as a response to these critiques and goals. Part IV returns to the task of redefining the Fourth Amendment search and invites the reader to complete the conceptual journey connecting rape law with search law. This section will demonstrate that in many significant ways, the grievances animating the rape reform movement can be analogized to the Fourth Amendment context, and indeed, one can discern a compelling parallel between the two areas of law. The section concludes by illustrating how the reforms achieved in the rape context can provide a model for reform in Fourth Amendment

$30 \quad$ See infra Part IV.

31 The focus of this Article is not to evaluate the reforms achieved in rape law, but to apply the reasoning and substance of those reforms to the context of defining Fourth Amendment searches. Although in order to accomplish this objective it is necessary to explore rape law in depth, this Article is really about Fourth Amendment searches. That said, there is a certain irony in urging a Fourth Amendment doctrine that will be more generous to defendants by highlighting rape law reforms that have made rape convictions easier to obtain, causing many scholars concern that, perhaps, certain of these reforms have gone too far and may raise the risk of unfairly convicting defendants accused of rape. See, e.g., Joshua Dressler, Where We Have Been, and Where We Might Be Going: Some Cautionary Reflections on Rape Law Reform, 46 Clev. St. L. Rev. 409 (1998) [hereinafter Dressler, Where We Have Been] (praising many of the legal reforms achieved while urging caution in moving forward in order to achieve a balance between the rights of victims and defendants).

$32 \quad 132$ S. Ct. 945 (2012). 
search doctrine as well, reform that can promote the goals of improved government behavior, individual autonomy, and equality. In concluding, the Article briefly highlights a few cases in which the Court has indicated its willingness to reconsider its post-Katz jurisprudence and which have set the stage for the beginnings of the shift in defining Fourth Amendment searches that has emerged in United States v. Jones, and that will, hopefully, continue to evolve.

\section{FROM 1967 TO 1984 AND BEYOND: DECONSTRUCTING AND RECONSTRUCTING KATZ}

\section{A. Nothing to Hide, Nothing to Fear . . But the Search Itself}

They rape us with their eyes, their laws, and their codes.

$$
\text { -Marilyn French }{ }^{33}
$$

There was no way of knowing whether you were being watched at any given moment. How often, or on what system, the Thought Police plugged in on any individual wire was guesswork. It was even conceivable that they watched everybody all the time.... You had to live—did live-from habit that became instinct - in the assumption that every sound you made was overheard, and, except in darkness, every movement scrutinized.

$$
\text { -George Orwell }{ }^{34}
$$

Just as the Article began, this section again juxtaposes two quotations to impress upon the reader the fundamental affront to personhood perpetrated through psychic, as well as physical, intrusions into private realms of life. Although we have not reached the Orwellian state of affairs described by the second quotation, we may be moving dangerously close. In 1984, the protagonist explains:

It was terribly dangerous to let your thoughts wander when you were in any public place or within range of a telescreen. The smallest thing could give you away. A nervous tic, an unconscious look of anxiety, a habit of muttering to yourself-anything that carried with it the suggestion of abnormality, of having something to hide. In any case, to wear an improper expression on your face... was itself a

33 MARILYN French, The Women's RoOM 433 (Ballantine Books 1977). The Women's Room was feminist novelist Marilyn French's debut novel, and the material quoted above was spoken by one of the novel's characters, preceded, however, by the following statement: "All men are rapists, and that's all that they are." Id. I chose to open Part II with this (quite controversial) quote to emphasize the concept of nonphysical means of breaching personal barriers.

34 GeORGE OrWELl, 19843 (Signet Classics 1950). 
punishable offense. There was even a word for it in Newspeak: facecrime . ... ${ }^{35}$

In Orwell's dystopian world, constant surveillance, whether through direct human observation or via telescreen, of facial and body expressions provided officials with information as to citizens' inner thoughts and emotions. Had Orwell been writing his novel today rather than in 1948, perhaps the Thought Police would have had even more effective means of "prob[ing] deeper and deeper into the reaches of our cognitive existence" ${ }^{\text {"6 }}$ by utilizing a process referred to as Brain Fingerprinting. ${ }^{37}$ Professor Christian Halliburton describes this process in the following way:

Brain Fingerprinting can tell the operator what an individual does or does not know without any voluntary action, response or consent by the subject. While Brain Fingerprinting can't "read minds" in the absolute sense, it does allow irresistible access to one's thoughts, with any decision to keep those thoughts and ideas private effectively overridden. ...

Professor Halliburton mentions various scientific techniques "designed to provide the means to tap into human cognitive contents and cerebral functioning for information-gathering ... purposes,",39 and continues:

The common thread uniting these complex and varied approaches is the belief that technological innovation can provide the power to peer behind the veil that keeps our thoughts and thought processes confidential, and that developing the power to do so ultimately serves the public good.

As experience has shown, the erosion of individual interests for the

$35 \quad I d$. at 145 .

36 Christian M. Halliburton, Letting Katz out of the Bag: Cognitive Freedom and Fourth Amendment Fidelity, 59 HASTINGs L.J. 309, 309 (2007) [hereinafter Halliburton, Cognitive Freedom].

37 See id.

38 Id. at 309-10.

39 See id. at 310. Professor Halliburton refers to these various methods as Cognitive Camera Technologies, or CCTs. Id. at 310. Brain Fingerprinting primarily utilizes electroencephalographic monitoring, although there are other techniques available and in use with the capability of providing access to our cognitive domain. $I d$. Brain Fingerprinting uses imagery to measure brain responses to selected stimuli, with the potential, for example, to indicate whether the subject has been previously exposed to a certain event or location. Halliburton, Cognitive Freedom, supra note 36, at 320 .

Id. at 310. 
"public good" is not only the stuff of (then) futuristic novels, but it is the stuff of Supreme Court opinions as well.

With advances in technology and, due in part to the War on Terror, the increased vigilance of the government, the importance of a more inclusive definition of a search cannot be understated. As Professor Anthony Amsterdam has asserted, "I can think of few issues more important to a society than the amount of power that it permits its police to use without effective control by law." ${ }^{41}$ To be sure, the most extreme intrusions upon individuals by the government are classified as searches and are, thus, regulated under the Fourth Amendment. Indeed, if the government seeks to retrieve evidence of crime by drugging a "citizen-not yet convicted of a criminal offense-with narcotics and barbiturates into a state of unconsciousness, and then to search beneath his skin for evidence of a crime," ${ }^{42}$ something more than probable cause and a warrant is required. ${ }^{43}$ Yet, under the special needs doctrine, the government may compel "a person to submit to the piercing of his skin by a hypodermic needle so that his blood may be extracted" ${ }^{44}$ with no individualized suspicion at all. ${ }^{45}$

41 Anthony G. Amsterdam, Perspectives On the Fourth Amendment, 58 MinN. L. REv. 349, 377 (1974)

${ }^{42}$ Winston v. Lee, 470 U.S. 753, 765 (1985) (internal quotations omitted).

43 The Court stated that the reasonableness of conducting surgical intrusions is properly determined on a case-by-case basis. $I d$. at 760 . Weighing the severity of the intrusion against the government's need to surgically retrieve a bullet from under the defendant's collarbone for use as evidence in an attempted robbery prosecution, the Court held the proposed surgery to be unreasonable, as this particular piece of evidence was not critical to the government's case and therefore, the government failed to demonstrate a compelling need for the bullet. Id. at 766 .

${ }^{44}$ Skinner v. Ry. Labor Execs.' Ass'n, 489 U.S. 602, 644 (1989) (Marshall, J., dissenting). At issue in Skinner were Federal Railroad Administration regulations concerning toxicological testing of the blood and urine of railroad employees directly involved in certain types of train incidents. Id. at 609-12.

${ }^{45} I d$. at 634 ("In light of the limited discretion exercised by the railroad employers under the regulations, the surpassing safety interests served by toxicological tests in this context, and the diminished expectation of privacy that attaches to information pertaining to the fitness of covered employees, we believe that it is reasonable to conduct such tests in the absence of a warrant or reasonable suspicion ...."). Skinner is one example of the Court's special needs doctrine, under which the usual requirements of a warrant and individualized suspicion are suspended and reasonableness is determined by balancing the severity of the intrusion upon the individual against the government's need to search in order to advance an interest unrelated to criminal law enforcement. See, e.g., Skinner v. Ry. Labor Execs.' Ass'n, 489 U.S. 602 (1989) (upholding Federal Railroad regulations that allowed toxicology tests of railroad employees without a search warrant or individualized suspicion); Nat'l Treas. Emp. Union v. Von Raab, 489 U.S. 656 (1989) 
The special needs doctrine also gives school administrators and officials relief from the warrant and probable cause requirements of the Fourth Amendment, permitting searches that are simply reasonable "under all the circumstances." " As documented in a 2009 New York Times article:

Savana Redding still remembers the clothes she had onblack stretch pants with butterfly patches and a pink Tshirt-the day school officials here forced her to strip six years ago. She was 13 and in eighth grade. An assistant principal, enforcing the school's antidrug policies, suspected her of having brought prescription-strength ibuprofen pills to school. One of the pills is as strong as two Advils. The search by two female school employees was methodical and humiliating, Ms. Redding said. After she had stripped to her underwear, "they asked me to pull out my bra and move it from side to side," she said. "They made me open my legs and pull out my underwear." Ms. Redding, an honors student, had no pills. ${ }^{47}$

Clearly, Savana Redding was the victim of a search, even, as it turned out, an unreasonable one. ${ }^{48}$ However, Ms. Redding was not entitled to relief in her suit against school officials because it was not "sufficiently clear" that forcing a 13-year-old girl to "expose[] her breasts and pelvic area" ${ }^{49}$ with no reason to suspect that the ibuprofen was being secreted in her underwear, would violate the Fourth Amendment. In other words, although the Court in T.L.O. warned officials that a search "excessively intrusive in light of the age and sex of the student and nature of the infraction" would not be reasonable,${ }^{50}$ and indeed described the strip search at issue here as a

(holding that the U.S. Customs Service's testing of employees who apply for promotion to positions directly involving the interdiction of illegal drugs, or to positions that require the incumbent to carry firearms, is reasonable despite the absence of a requirement of probable cause or of some level of individualized suspicion); Griffin v. Wisconsin, 483 U.S. 868 (1987) (stating that supervision of probationers is a "special need" of the State that may justify departures from the usual warrant and probable cause requirements); Camara v. Municipal Court, 387 U.S. 523 (1967) (upholding administrative home searches). But see Ferguson v. City of Charleston, 532 U.S. 67 (2001) (holding that a hospital's mandatory drug screening of pregnant women is a type of search that does not meet the special needs criteria).

${ }^{46}$ New Jersey v. T.L.O., 469 U.S. 325, 326 (1985).

Adam Liptak, Strip-search of Girl Tests Limit of School Policy, N.Y. TIMEs, March 23, 2009, at A1, available at http:/ /www.nytimes.com/2009/03/24/us/24savana.html.

48 Safford Unified Sch. Dist. No. 1 v. Redding, 557 U.S. 364, 379 (2009).

$49 \quad I d$. at 369.

50 T.L.O., 469 U.S. at 342. 
"quantum leap from outer clothes and backpacks to exposure of intimate parts," ${ }^{, 51}$ it was apparently still not sufficiently clear that this was excessively intrusive, and therefore the officials were entitled to qualified immunity. ${ }^{52}$

While Savana Redding at least could claim the satisfaction of knowing that her outrage was legally justified (though not compensable), Max Rettele, his girlfriend Judy Sadler, and her son Chase Hall were told, in a per curium decision, that, despite the fact that the "frustration, embarrassment, and humiliation" they suffered was "real," ${ }^{53}$ seven deputies acted reasonably ${ }^{54}$ when, executing a warrant for the search of a home for African-American suspects of fraud and identity theft, they entered the home of Rettele, Sadler, and Hall (all Caucasian) at 7:15 A.M., unaware that Rettele had purchased and moved into the home three months before the search. ${ }^{55}$ Hall, upon answering the door to the deputies, was ordered "to lie face down on the ground." ${ }^{56}$

The deputies' announcement awoke Rettele and Sadler. The deputies entered their bedroom with guns drawn and ordered them to get out of their bed and to show their hands. They protested that they were not wearing clothes. Rettele stood up and attempted to put on a pair of sweatpants, but deputies told him not to move. Sadler also stood up and attempted, without success, to cover herself with a sheet. Rettele and Sadler were held at gunpoint for one to two minutes before Rettele was allowed to retrieve a robe for Sadler. He was then permitted to dress. . . By that time the deputies realized they had made a mistake. They apologized to Rettele and Sadler, thanked them for not becoming upset, and left within five minutes. ${ }^{57}$

The Court, in reaching its decision, mentioned that the officers left the home less than one quarter hour after having arrived, and that Ms. Sadler was "unclothed for no more than two minutes, and Rettele for only slightly more time than that. ${ }^{, 58}$ One cannot help but wonder how long those two minutes felt to Sadler and Rettele,

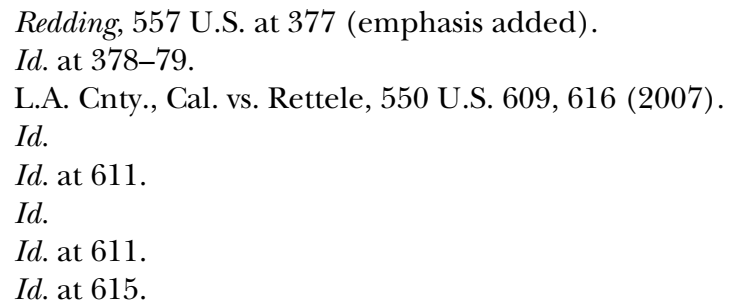


standing naked in front of seven deputies and their drawn guns.

It is worth leaving the reader with one more example of a physically invasive search, one is commonly experienced by many citizens, especially those who frequently travel by air. ${ }^{59}$ While the examples above all constitute searches, the Terry frisk also qualifies as a search, but requires only reasonable suspicion because it is deemed to be less intrusive than a full search, ${ }^{60}$ although still a "serious intrusion upon the sanctity of the person." Ohio, asks us to

[c]onsider the following apt description: "The officer must feel with sensitive fingers every portion of the prisoner's body. A thorough search must be made of the prisoner's arms and armpits, waistline and back, the groin and area about the testicles, and entire surface of the legs down to the feet." ${ }^{\prime 2}$

If "such a procedure performed in public by a policeman while the citizen stands helpless" Amendment protection under the Court's balancing approach, it should not be surprising that a great many intrusions warrant no Fourth Amendment protection at all. In fact, one view of Terry is that the balance struck by the Court, accommodating law enforcement needs while taking into account the individual interest, is preferable to one alternative: not classifying anything short of a full arrest and search as implicating the Fourth Amendment at all, thereby leaving police officers completely to their discretion to "merely" stop and frisk with no judicial oversight. ${ }^{64}$ Of course, this is precisely the result

59 I refer to the frisk that many travelers are required to endure as a condition to boarding an airplane, either in lieu of agreeing to a full-body scan by the back-scatter $\mathrm{x}$-ray machines in use at many airports, or upon some indication from the x-ray that indicates a need for the frisk. These airport frisks are sufficiently routine, however, that they likely do not equal the humiliation and embarrassment felt by the individual receiving a frisk, based on suspicion, on a public sidewalk in full view of gawking passersby.

${ }^{60}$ Terry v. Ohio, 392 U.S. 1, 26 (1968) (describing the frisk as "something less than a 'full' search.").

Id. at 17.

62 Id. at 17 n.13 (quoting Priar \& Martin, Searching and Disarming Criminals, $4 \mathrm{~J}$. Crim. L., Criminology \& Police SCI. 481 (1954)).

63 Terry, 392 U.S. at 16-17.

64 See Eric J. Miller, The Warren Court's Regulatory Revolution in Criminal Procedure, 43 ConN. L. REV. 1, 48-65 (2010) (arguing that Terry actually expanded regulation of law enforcement to include judicial oversight over areas of citizen-police encounters that fell outside the usual warrant and probable cause standard). But see Amy D. Ronner, Fleeing While Black: The Fourth Amendment Apartheid, 32 Colum. Hum. RTs. L. 
with a great many surveillance techniques the Court has classified as non-searches: permitting police, at their whim, to peer into our back yards from hovering aircraft, ${ }^{65}$ probe into our personal relationships by tracking whom we telephone ${ }^{66}$ stalk us in public with electronic devices, ${ }^{67}$ rummage through our garbage ${ }^{68}$ delve into our personal finances, ${ }^{69}$ and yes, even search our friends' cars as we ride with them. $^{70} \quad$ Professor Amsterdam is correct: there are few more important issues.

\section{B. A First Look at Katz: Was It All We Expected?}

In 1967, the Supreme Court famously announced that "the Fourth Amendment protects people, not places." With that bold statement, the Warren Court sought to expand the scope of the Fourth Amendment ${ }^{72}$ by rejecting the traditional requirement of a physical trespass into a "constitutionally protected area" as the trigger for Fourth Amendment protection against unreasonable searches. ${ }^{73}$ Thus, Mr. Katz successfully claimed a violation of the Fourth Amendment when government agents, acting without a warrant, listened to and recorded his side of a telephone conversation by

REv. 383, 400 (2001) (referring to Terry as the "foundation upon which the Supreme Court has built its racially biased Fourth Amendment jurisprudence"). Professor Ronner argues that the Court briefly acknowledged, and then repressed and negated, the awareness that stop and frisks could be, and often were, used by police as tools of harassment and humiliation directed against minority citizens, a practice that would likely increase in light of the reduced Fourth Amendment protection afforded citizens by the reasonable suspicion standard, and a practice the Court found the exclusionary rule ineffective to control. Id. at 404-05. With its decision in Terry, Professor Ronner claims, the Court effectively "inaugurated what was to become an insidious pattern-namely the exile of minorities from the dominion of Fourth Amendment protection." Id. at 405-06.

65 See Florida v. Riley, 488 U.S. 445 (1989); California v. Ciraolo, 476 U.S. 207 (1986).

See Smith v. Maryland, 442 U.S. 735 (1979).

67 See United States v. Knotts, 460 U.S. 276 (1983).

68 See California v. Greenwood, 486 U.S. 35 (1988).

See United States v. Miller, 425 U.S. 435 (1976).

See Rakas v. Illinois, 439 U.S. 128 (1978).

Katz v. United States, 389 U.S. 347, 351 (1967).

${ }^{72}$ See U.S. Const. amend. IV. "The right of the people to be secure in their persons, houses, papers, and effects, against unreasonable searches and seizures, shall not be violated, and no Warrants shall issue, but upon probable cause, supported by Oath or affirmation, and particularly describing the place to be searched, and the persons or things to be seized." Id.

${ }^{73}$ See Katz, 389 U.S. at 350. "[T] he correct solution of Fourth Amendment problems is not necessarily promoted by incantation of the phrase "constitutionally protected area." Id. 
affixing electronic recording equipment to the outside of the telephone booth he used to place his call, despite the facts that he had no traditional property interest in the public booth (the inside of which was partially exposed to public view) ${ }^{74}$ the electronic device did not physically intrude into the phone booth, and the words spoken by him could not be "seized" in the usual meaning of the word. $^{75}$ Thus, Mr. Katz received the protection of the Fourth Amendment not because he claimed some property right to an invaded place, but because the "Government's activities in electronically listening to and recording the petitioner's words violated the privacy upon which he justifiably relied . . .",76

So, if Katz was meant to herald a new age of expansive Fourth Amendment protection broadly available to all "people" based on some inherent right to privacy ${ }^{77}$ rather than upon the ability to assert

$74 \quad$ Id. at 352.

${ }^{75}$ See id. at 348-49, 353, 359. Justice Black, in dissent, criticizes the majority for straying so far from the text of the Fourth Amendment, which he reads to protect against the unreasonable search and seizure of tangible things, concluding that the Amendment simply does not apply to eavesdropping, whether by naked ear or with the assistance of technology. Id. at 365-66 (Black, J., dissenting).

76 Id. at 353. This is not to say, however, that property law is irrelevant in determining the existence of one's right under the Fourth Amendment to be free from governmental intrusions, as the Court in United States v. Jones, 132 S. Ct. 945 (2012), has recently recognized. See supra notes 17-24 and accompanying text. The Court has finally heeded the many scholars who have disapproved of the conventional view that Katz outright rejected any reliance on property law in favor of a privacy-based regime, and who have argued, instead, that the focus on privacy was meant to supplement the existing property framework, thereby expanding the protective reach of the Amendment. See, e.g., Christian M. Halliburton, How Privacy Killed Katz: A Tale of Cognitive Freedom and the Property of Personhood as Fourth Amendment Norm, 42 AKRon L. REv. 803, 824-25 (2009) [hereinafter Halliburton, How Privacy Killed Katz]

[T] he Katz opinion does not wholly require, nor justify, the shift from a property to a privacy perspective that we attribute to it. The most salient aspects of the Katz Court's analysis ... are its rejection of the limitations of the trespass doctrine and the refusal to invest any significance in the difference between tangible and intangible items. The trespass doctrine itself is not wholly irrelevant after Katz because Katz merely held that a trespass is not necessary to trigger the Fourth Amendment, but it nowhere stated that it is insufficient.

Id. (emphasis in original); Orin S. Kerr, The Fourth Amendment and New Technologies: Constitutional Myths and the Case for Caution, 102 MiCH. L. REv. 801, 816 (2004) ("While existing scholarship often interprets the shift [in $\mathrm{Katz}$ ] as a wholesale rejection of property-based principles... it is better understood as a shift of degree from common law rules to the looser property-based approach that currently governs.").

77 Justice Black also accuses the majority of "clever word juggling" and of "rewriting the Fourth Amendment" to reconstruct that Amendment as a law protecting privacy rather than one prohibiting unreasonable searches and seizures. 
a sufficient property interest in a given location (which would limit the number of individuals qualifying for protection), ${ }^{78}$ how did we get to the state of affairs described above? Perhaps the fault lies somewhat with Justice Stewart's Katz opinion itself. While dismantling the existing trespass doctrine, the Katz majority did not clearly construct its replacement, ${ }^{79}$ leaving Justice Harlan, in his concurring opinion, to offer his understanding of the majority's holding, still in terms of places and areas, but with an emphasis on the privacy an individual may expect in association with those places and areas rather than with a sole focus on any property interest that may be claimed. ${ }^{80}$ Thus, for Justice Harlan, the phone booth into which Mr. Katz entered, after he shut the door and paid his toll, became a "temporarily private place whose momentary occupants' expectations of freedom from intrusion are recognized as reasonable." ${ }^{\prime 1}$ It was Justice Harlan's concurrence that provided the two-pronged test that came to define a search as a government violation of "an actual, subjective expectation of privacy" that "society is prepared to recognize as 'reasonable." "82 This Article will show, however, that Justice Harlan's formulation is capable of a much more

See Katz, 389 U.S. at 373 (Black, J., dissenting).

78 Justice Alito, in his concurring opinion in Jones, urged the continued need to look to reasonable expectations of privacy, noting that the physical trespass-based approach would not have protected the defendant if, for example, the GPS device had been affixed to the car before it came under his exclusive control or if the Government made use of a GPS device already installed upon the car by the manufacturer. See Jones, 132 S. Ct. at 961 (Alito, J., concurring). Of course, the irony lies in the fact that the reasonable expectation of privacy test has also been used to limit the number of individuals who can successfully claim the protection of the Fourth Amendment, as demonstrated in many of the Court's "standing" cases. See, e.g., Rakas v. Illinois, 439 U.S. 128 (1978) (holding that defendants who were mere passengers in an automobile did not have a legitimate expectation of privacy in the portions searched); Rawlings v. Kentucky, 488 U.S. 98 (1980) (holding that defendant did not have a legitimate expectation of privacy in his companion's purse).

${ }^{79}$ See James J. Tomkovicz, Beyond Secrecy for Secrecy's Sake: Toward an Expanded Vision of the Fourth Amendment Privacy Province, 36 HASTINGS L.J. 645, 650-51 (1985) (describing the Katz majority opinion as "an efficient dismantler, but neglectful reconstructor").

${ }^{80}$ Katz, 389 U.S. at 360-61 (Harlan, J., concurring).

${ }^{81} \quad I d$. at 361 .

82 Id. The Court officially adopted Justice Harlan's formulation defining a Fourth Amendment search in Smith v. Maryland, 442 U.S. 735, 740 (1979), taking care to link each of the two prongs of Justice Harlan's test to Justice Stewart's language in the Katz majority opinion. See Katz, 389 U.S. at 361. It is also important to remind the reader that, even after United States v. Jones, 132 S. Ct. 945 (2012), this remains the test of a search in the absence of a physical trespass into a constitutionally protected area. 
nuanced and subtle application than the Court has chosen to endorse, especially when read carefully in conjunction with Justice Stewart's majority opinion.

A careful reexamination of Katz, with greater fidelity to both language and intent, is particularly urgent, in light of the twin pressures of a perceived need for both increased surveillance (making government surveillance more frequent and routine) and technological innovation (making such surveillance more effective and revealing), both of which act on the current definition of a search by consistently eroding societal expectations of privacy. Thus, a definition of a search that focuses solely on those continually diminishing expectations to delineate the scope of constitutional protection will result in a Fourth Amendment that increasingly permits the very entity meant to be cabined by that Amendment ever more power:

[S] earches are defined as anything agents of the government do that infringes a reasonable expectation of privacy. As every criminal procedure class learns, if the key to that definition is the word "expectation," the definition is circular. People expect what they think will happen, and what they think will happen is a function of what has happened in the past. By altering its behavior, the government can change how people expect it to behave. Thus, if the government is bound only to respect people's expectations, it is not bound at all, for it can easily condition the citizenry to expect little or no privacy. ${ }^{83}$

Ironically, although the Katz Court found the prior property and trespass-based approach to defining a search inadequate to protect citizens against the government's use of novel, high-tech forms of surveillance, its privacy-based solution, especially when distilled into Justice Harlan's two-pronged reasonable expectation test, has proved vulnerable to manipulation and equally inadequate (as it has been interpreted and applied) to protect privacy. Katz has left significant questions unanswered, even with Justice Harlan's clarification of the Court's holding, and has generated significant debate and criticism

83 William J. Stuntz, The Distribution of Fourth Amendment Privacy, 67 GEO. WASH. L. REv. 1265, 1268 (1999). As Professor Thomas Clancy observed, "[t] he peculiar logic of the diminished expectation of privacy rationale, therefore, is that it permits the scope of Fourth Amendment protections to diminish as governmental regulation increases. Yet, the mandates of the Fourth Amendment demand heightened, not lowered, respect, as the intrusive regulatory authority of government expands." Thomas K. Clancy, What Does the Fourth Amendment Protect: Property, Privacy, or Security?, 33 WAKE FOREST L. REV. 307, 342 (1998) (internal quotations omitted). 
among scholars and Justices alike, as has the Court's post-Katz jurisprudence. $^{84}$

Justice Black, in his Katz dissent, reiterated his "fear of the dangers involved when [the] Court uses the broad, abstract and ambiguous concept of privacy as a comprehensive substitute for the Fourth Amendment's guarantee against unreasonable searches and seizures." ${ }^{\text {55 }}$ Justice Black continued by expressing his grave reservations concerning the adoption of such an amorphous standard by which to define the scope of the Fourth Amendment (substituting a general right to privacy for the concrete terms of the Amendment, giving the Court "unlimited power to hold unconstitutional everything which affects privacy").

84 See generally Minnesota v. Carter, 525 U.S. 83, 91, 93 (1998) (Scalia, J., \& Thomas, J., concurring) (describing the legitimate expectation of privacy as providing a "fuzzy standard" and further critiquing Justice Harlan's formulation of the Katz test as, at least in light of the case law generated in the three decades after that test was announced, as "self-indulgent"); Sherry Colb, What Is a Search?: Two Conceptual Flaws in Fourth Amendment Doctrine and Some Hints of a Remedy, 55 STAN. L. REv. 119, 120-21 (2002) (noting her agreement with numerous scholars who critique the Court's post-Katz decisions as so narrowly defining "the scope of protected privacy ... that much of the universe of investigative activity does not even trigger the Fourth Amendment's reasonableness requirements" and arguing that the doctrinal "moves" the Court has made in its decisions have eroded and threaten to altogether eradicate privacy); Halliburton, How Privacy Killed Katz, supra note 76, at 810 (describing the Court's privacy doctrine as "schizophrenic" and criticizing the Katz Court for "articulat[ing] a descriptive explanation of its decision that masquerades as a principle"); William C. Heffernan, Fourth Amendment Privacy Interests, 92 J. CRIM L. \& CRIMINOlogY 1, 3, 35 (2001) (arguing that the Court has "hardly... shown a serious concern for privacy" and describing the results of the Court's application of Katz as "deplorable"); Brian J. Serr, Great Expectations of Privacy: A New Model for Fourth Amendment Protection, 73 MinN. L. REv. 583, 584 (1989) (arguing that the Court, in interpreting the Fourth Amendment, has "tipped the balance unnecessarily further and further away from individual freedom, significantly diminishing the realm of personal privacy," and critiquing the Court's application of Katz to a variety of situations and advocating for a new model of protection based on degrees of exposure); Tomkovicz, supra note 79, at 647 (arguing that Katz did not provide much guidance with respect to the application of its new paradigm, leading the Court to refine and develop the doctrine, unfortunately in ways that have "neither fulfilled the promises of Katz nor been consonant with an appropriately conceived fourth amendment core").

85 Katz, 389 U.S. at 374 (Black, J., dissenting) (quoting Griswold v. Connecticut, 381 U.S. 479, 507-27 (1965) (Black, J., dissenting)) (internal quotation marks omitted).

${ }^{86}$ Katz, 389 U.S. at 374 . Justice Black continued, "Certainly the Framers, well acquainted as they were with the excesses of governmental power, did not intend to grant this Court such omnipotent lawmaking authority as that. The history of governments proves that it is dangerous to freedom to repose such powers in courts." Id. 
What Justice Black did not predict, however, was that rather than holding unconstitutional all investigative conduct of police that impinges on a suspect's privacy, the post-Warren Court would use the very test meant to expand protection of the Fourth Amendment beyond traditional and rigid notions of property and trespass to, in fact, narrow the Amendment's protective reach. Thus, in the hands of a more conservative Court, the reasonable-expectation-of-privacy test resulted in a great many investigative techniques being deemed non-searches, and thus, subject to no constitutional scrutiny whatsoever. ${ }^{87}$ As one scholar has noted,

Today, it is common to find scholarly discussion of Supreme Court "search" cases that is highly alarmist in tone. Indeed, it is difficult to disagree with the view that these decisions describe a society too redolent of the totalitarian: no business relationship is confidential, especially with banks and utilities; the use of an automobile, especially as a passenger, must be avoided; only in your own home are you secure, and then only if you live alone, do not have guests, do not share, and keep the windows covered and the door bolted. ${ }^{88}$

Returning to Justice Harlan's formulation of the reasonableexpectation-of-privacy test and the Court's application of that test, it is appropriate, put plainly, to question whether the Court got it right. Do individuals truly expect that the phone company will (or should) release the numbers dialed from inside one's home upon request simply because placing a call necessarily requires divulging the number of the intended recipient to the phone carrier for connection? ${ }^{89}$ Is it objectively unreasonable to expect that the police, whose behavior should serve as a model, will refrain from sifting through one's curbside garbage, even though "animals, children, scavengers, snoops, and other members of the public" could (although not necessarily would or commonly do) engage in such rubbish-rummaging practices? ${ }^{90}$ Does society not accept as legitimate

87 See supra notes 65-70 and accompanying text.

88 Peter Goldberger, Consent, Expectations of Privacy, and the Meaning of "Searches" in the Fourth Amendment, 75 J. CRIM L. \& CRIMINOLOGY 319, 323 (1984).

89 See Smith v. Maryland, 442 U.S. 735, 745 (1979) (holding that the use of pen registers to disclose the numbers dialed from inside of defendant's home was not a search, because the defendant "in all probability entertained no actual expectation of privacy in the phone numbers he dialed, and that, even if he did, his expectation was not 'legitimate"”).

90 See California v. Greenwood, 486 U.S. 35, 40 (1988) (holding that there is no reasonable expectation of privacy in garbage left at the curb for pickup). 
the expectation that we won't be hovered over and peered at in our fenced back yards, like exhibits in a menagerie, by police, simply because the helicopter from which they are staging their observation maintains the minimal height permitted by aviation safety regulations? ${ }^{91}$ Or, is the expectation preposterous that, if we place an item in the glove compartment of a companion's car as we ride together, police will not have unfettered access to that item simply because we are guests in, rather than the owners of, the car? ${ }^{92}$

It is no happy coincidence, as noted by Justice Scalia, that "those actual (subjective) expectation[s] of privacy that society is prepared to recognize as reasonable bear an uncanny resemblance to those expectations of privacy that this Court considers reasonable." ${ }^{.93}$ And, when, due to social or political pressures, ${ }^{94}$ the majority of the Court is inclined to place a finger on the scale of reasonableness to tip the balance in favor of law enforcement interests, ${ }^{95}$ that same Court will likely find an expansive notion of privacy to be unreasonable, regardless of what expectations society actually holds. ${ }^{96}$

How the Court determines the question of reasonableness should be a matter of grave importance to anyone concerned with maintaining some sphere of personal dominion. After all, once the Court decides that a defendant has no expectation of privacy in a given context, the government may seek and find, but still will not

91 See Florida v. Riley, 488 U.S. 445 (1989) (holding that surveillance conducted from a helicopter at four hundred feet did not constitute a search).

92 See Rakas v. Illinois, 439 U.S. 128, 148 (1978) (holding that defendants, as "mere passengers" had no "legitimate expectation of privacy in the glove compartment or area under the seat of the car" in which they were traveling, as they "asserted neither a property nor a possessory interest in the automobile").

93 Minnesota v. Carter, 525 U.S. 83, 97 (1998) (Scalia, J., dissenting) (internal citations and quotation marks omitted).

${ }^{94}$ President Nixon was elected, in part, on a "law and order" platform and, during his presidency, had the opportunity to nominate four conservative Justices to the Supreme Court: Chief Justice Burger and Justices Blackmun, Rehnquist, and Powell.

${ }_{95}$ See Tracey Maclin, Constructing Fourth Amendment Principles from the Government Perspective: Whose Amendment Is It, Anyway?, 25 AM. CRIM. L. REV. 669, 669 (1987) [hereinafter Maclin, Government Perspective] (arguing that the Court's post-Katz Fourth Amendment doctrine is fashioned from a police perspective, rather than from a perspective favoring the individual interests of those who are the subject of police investigation).

${ }^{96}$ See Christopher Slobogin \& Joseph E. Schumacher, Reasonable Expectations of Privacy and Autonomy in Fourth Amendment Cases: An Empirical Look at 'Understandings Recognized and Permitted By Society', 42 Duke L.J. 727 (1993) (offering stark empirical evidence that judges often incorrectly assess which expectations of privacy society considers to be reasonable or unreasonable). 
have searched, thus leaving its conduct and methods completely beyond judicial reproach. ${ }^{97}$ And, while the reasonable-expectation-ofprivacy test often leads to the odd conclusion that seeking is not searching, the Court's standing doctrine, and its merger of standing and substance, creates an even greater paradox, as now searching is not always searching either. ${ }^{98}$

This merger of standing and merits effectively narrows the set of defendants who are even permitted to bring the government's conduct to a court's attention, which in turn allows fewer opportunities to develop search and seizure law at a time when the

97 Justice Scalia was clearly aware of the tension between the common understanding of what it means to "search" for something and the Court's insistence on classifying purposeful visual inspection on the part of police as somehow not being a search, offering the explanation that the Court avoided the alternative means to validate warrantless surveillance-acknowledging it as a search, but holding it to be reasonable-"perhaps in order to preserve somewhat more intact [the] doctrine that warrantless searches are presumptively unconstitutional." Kyllo v. United States, 533 U.S. 27, 32 (2001). Of course, there is a point, as the Court observed in Terry v. Ohio, 392 U.S. 1 (1968), in upholding as reasonable warrantless frisks based on reasonable suspicion of criminal activity, where it becomes "nothing less than sheer torture of the English language to suggest" that a highly intrusive inspection, such as the "careful exploration of the outer surfaces of a person's clothing all over his or her body" at issue in Terry is not a search. Id. at 16-17.

98 For example, when police search the glove compartment referred to above, they have conducted a Fourth Amendment search, at least with respect to the owner of the car. However, with respect to the passenger, the identical conduct of the police in opening and looking into the glove compartment is transformed into a non-search because the passenger cannot legitimately expect the contents of the glove compartment to remain private, even though that is precisely what the owner of the car can and does expect. Ironically, while maintaining that the car owner retains a reasonable expectation of privacy in the vehicle, her actual privacy is more likely to be invaded because police may have an incentive to search automobiles with multiple passengers, knowing that any incriminating evidence found will likely be admissible against the passengers (assuming a lawful stop) in the event of a criminal prosecution. This, of course, demonstrates why Professor Stuntz described the reasonable expectation of privacy test as "circular." See Stuntz, supra note 83, at 1268, and accompanying text. I have previously expressed my concern that this approach to standing could affect the scope of Fourth Amendment protection even as to the owner of the car, when she chooses to invite others inside. See Soree, supra note 7, at 619-20 ("After all, how can I, driving down the freeway on my way to work, reasonably expect that the government will not intrude into my car when my coworker, to whom I've offered a lift, sitting alongside me in the same car, expects exactly the opposite?"). Justice Ginsburg, expressed precisely this concern in Minnesota v. Carter, 525 U.S. 83 (1998), which held that individuals inside a home for a limited period solely to conduct business did not have a legitimate expectation of privacy in the home: "As I see it, people are not genuinely 'secure in their... houses... against unreasonable searches and seizures... if their invitations to others increase the risk of unwarranted governmental peering and prying into their dwelling places." Carter, 525 U.S. at 108 (Ginsburg, J., dissenting). 
privacy rights of citizens may be in need of the most protection. The paradox identified above can be addressed by redefining the Katz test to take the government's conduct into account. This Article argues that, in fact, the government's conduct must be considered in the context of answering two substantive questions: first, whether a legitimate expectation of privacy has been invaded; and second, whether such invasion is constitutionally permissible, with the focus of this Article on the former inquiry. Under the conduct-oriented approach proposed herein, the conduct of both police and defendants will play a role in determining whether government surveillance is a search, triggering the protection of the Fourth Amendment.

\section{A Second Look at Katz: Conduct in the Content}

Despite the oft-noted lack of clarity in the Katz opinion, a careful examination of the language contained in that opinion, as well as in Justice Harlan's concurrence, will reveal support for this more balanced, conduct-oriented approach to defining a search. This Article has already shown that the Katz Court sought to expand the reach of the Fourth Amendment by rejecting sole reliance on property concepts to define the parameters of a search, traditionally limited to physical intrusions into traditionally protected places or areas (such as a home, for example). Chartering new territory, the Katz Court chose to define a search by focusing on what an individual "seeks to preserve as private" "99 as meriting Fourth Amendment protection, versus that which "a person knowingly exposes to the public," ${ }^{100}$ without defining the individual's intentions with respect to disclosure or nondisclosure solely in reference to her location at the time of the search, or non-search, as the case may be. ${ }^{101}$

${ }^{99}$ Katz, 389 U.S. at 351.

100 Id.

101 See id. In fact, if those phrases are read in the context of the full sentences in which they appear, it is clear that the Court went further than simply stating that an individual's presence in a protected area is not dispositive to the question of whether or not a search has occurred, and the Court used two diametrically opposed locations to make its point: the home (or office) and a publicly accessible area. See $i d$. Thus, an individual located inside the home, an area that has consistently received the greatest protection and deference, may nonetheless relinquish Fourth Amendment protection through her actions in exposing information or objects to public view, while an individual in public may nevertheless still claim the protection of the Fourth Amendment because of her efforts to maintain something as private. See id. "What a person knowingly exposes to the public, even in his own home or office, is not a subject of Fourth Amendment protection. But what he seeks to preserve as private, even in an area accessible to the public, may be constitutionally 
This is not to say that places and areas are irrelevant. As Justice Harlan noted in his concurring opinion, determining the level of protection the Fourth Amendment confers on an individual "[g]enerally... requires reference to a "place."”102 Since the Court formally adopted Justice Harlan's formulation as the definition of a Fourth Amendment search, ${ }^{103}$ his opinion merits careful attention. I quote (again) the actual language setting out Justice Harlan's twoprong test: "there is a twofold requirement, first that a person have exhibited an actual (subjective) expectation of privacy and, second, that the expectation be one that society is prepared to recognize as 'reasonable." "104 Note what is missing from this language: there is no reference to an area or place directly after "expectation of privacy." To be sure, Justice Harlan began his opinion with the "reading" of the Court's opinion as holding that "an enclosed telephone booth is an area where, like a home, and unlike a field, a person has a constitutionally protected reasonable expectation of privacy." ${ }^{105}$ However, Justice Harlan qualified the assertion that a home, for example, is an area giving rise to a reasonable expectation of privacy a bit later in his opinion, stating that "a man's home is, for most purposes, a place where he expects privacy," while conversations held in the open, or indeed objects exhibited in the plain view of outsiders, are not constitutionally protected from discovery because there is no objectively discernible intention to keep these conversations or objects hidden. ${ }^{106}$

Thus, a constitutionally recognized expectation of privacy derives its reasonableness from all the circumstances surrounding its breach by the police, which include, but are not limited to, the individual's location in a given place or area. Returning to Mr. Katz in his phone booth, we see that the nature of what the person seeks to keep private also informs the determination of whether or not an expectation of privacy is reasonable; this refers to "nature" in its general, rather than in its most specific, sense. ${ }^{107}$ Because Mr. Katz

protected." Id. (internal citation omitted).

102 Id. at 361 (Harlan, J., concurring).

103 See Smith v. Maryland, 442 U.S. 735, 740 (1979).

104 Katz, 389 U.S. at 361.

$105 \quad I d$. at 360.

106 Id. at 361 (emphasis added). Justice Harlan's caveat, then, regarding the home as a place where one usually, but not always, can expect privacy is entirely consistent with the majority's language with respect to knowing exposure, even from the home. Id.

${ }^{107}$ Thus, it suffices to note that Mr. Katz was intending to keep a conversation 
sought to keep a conversation private, the phone booth became an area from which he could (and should) reasonably expect to do just that. If instead, however, Mr. Katz decided to disrobe inside the phone booth, or decided to dismantle and damage the telephone, he would have had no legitimate expectation of not being seen and consequently arrested for indecent exposure or destruction of property, as the case may be, despite the fact that the activities would have taken place in the very same "area." It is, in other words, highly relevant that Mr. Katz sought to exclude from the glass phone booth "not the intruding eye," but the "uninvited ear."108

Many scholars have analyzed and identified various factors that the Court takes into account when determining whether a defendant can claim a reasonable expectation of privacy, trying to give content to what is often described as an open-ended and amorphous test. ${ }^{109}$ But such a lack of structure may be precisely what Justice Stewart and the Katz majority had in mind-to supplement a rigid doctrine based solely on trespass and property rights with one more capable of meeting the challenges to privacy presented by the advance of technology and the modern reality of living in a highly regulated society. Just as the Framers could not possibly have anticipated the electronic device used by government agents in Katz, perhaps the Katz majority also strove to create a test flexible enough to withstand technologies that the Court, writing its opinion in 1967, also could not predict.

Of course, the danger with creating such an open test is that, rather than accepting the invitation Katz arguably offered to establish a more nuanced, balanced approach to defining searches, courts may instead opt for an uncritical application of the test that simply provides the desired outcome. A mere four years after Katz, Justice Harlan himself expressed concern that the Court's application of Katz lacked normative content and vigorously dissented from the result in United States $v$. White, in which the Court held that the government's surreptitious listening to the defendant's conversation

private, without taking into account the subject of the conversation. After all, Mr. Katz's conversation could be viewed as a type of contraband, as he was convicted under a statute prohibiting the transmission of gambling information through wire communication. See id. at 348 n.1 (setting out 18 U.S.C. $\$ 1084$ ).

108 Katz, 389 U.S. at 352.

109 See, e.g., Michael Campbell, Defining a Fourth Amendment Search: A Critique of the Supreme Court's Post-Katz Jurisprudence, 61 WASH. L. REV. 191 (1986); Goldberger, supra note 87; Richard G. Wilkins, Defining the "Reasonable Expectation of Privacy": An Emerging Tripartite Analysis, 40 VAND. L. REV. 1077 (1987). 
with an informant wearing a concealed radio transmitter did not violate the Fourth Amendment. ${ }^{110}$ The Court, in reaching its decision, relied on the misplaced trust, or assumption-of-risk, rationale of Hoffa v. United States, ${ }^{111}$ Lewis v. United States, ${ }^{112}$ and Lopez v. United States, ${ }^{113}$ which was left undisturbed by the test announced in Katz. ${ }^{114}$ In other words, when one chooses his confidences unwisely, and assumes the risk that the one to whom he is speaking is in fact a government agent or informant, he cannot justifiably rely on an expectation of privacy. In his dissent, Justice Harlan stated,

While these formulations represent an advance over the unsophisticated trespass analysis of the common law, they too have their limitations and can, ultimately, lead to the substitution of words for analysis. The analysis must, in my view, transcend the search for subjective expectations or legal attribution of assumptions of risk. Our expectations,

110 United States v. White, 401 U.S. 745 (1971). The various conversations overheard by government agents included a conversation taking place in the defendant's home. Id. at 747. For Justice Harlan's dissenting opinion, see $i d$. at 768-95 (Harlan, J., dissenting).

111385 U.S. 293 (1966) (holding that information received from a secret government informer and used to obtain a conviction of James Hoffa, the Teamsters' union leader, did not constitute an illegal search, because the informer was an invited guest).

112385 U.S. 206, 211 (1966) ("When the home is opened as a place of illegal business to which outsiders are invited for commercial purposes, the Fourth Amendment is not violated when a government agent enters pursuant to an invitation and then neither sees, hears, nor takes anything either unrelated to the business purpose of his visit or not contemplated by the occupant.").

113373 U.S. 427 (1963) (holding that an undercover agent's secretive wire recording of a conversation with defendant did not violate defendant's Fourth Amendment rights, despite the fact that the conversation took place in defendant's office).

114 In reaching its decision, the Court reversed the Court of Appeals, which had found that simultaneous broadcasting of the conversation at issue in White violated Katz, and thus, the Fourth Amendment. See White, 401 U.S. at 745. The Court of Appeals had reasoned that, although Hoffa, Lewis, and Lopez remained good law after Katz, On Lee v. United States, 343 U.S. 747 (1952), a case, like White, also involving realtime broadcasting of a conversation, did not survive, prompting its decision in favor of the defendant. White, 401 U.S. at 745. The Supreme Court upheld On Lee, based not on the original rationale of the case-that there was no Fourth Amendment violation in the absence of a physical trespass-as that reasoning was rendered irrelevant after $\mathrm{Katz}$, but based on the alternate argument that the defendant in $\mathrm{On}$ Lee "was talking confidentially and indiscreetly with one he trusted, and he was overheard ...." Id. at 750 (quoting On Lee, 354 U.S. at 753-54). Thus, the Supreme Court was able to maintain its previous precedents condoning the use of informants and undercover officers (a significant source of information for law enforcement) without reliance on trespass doctrine, by fitting that type of surveillance into Katz's reasonable expectation of privacy framework. See White, 401 U.S. at 750. 
and the risks we assume, are in large part reflections of laws that translate into rules the customs and values of the past and present.... [W]e should not, as judges, merely recite the expectations and risks without examining the desirability of saddling them upon society. The critical question, therefore, is whether under our system of government, as reflected in the Constitution, we should impose on our citizens the risks of the electronic listener or observer without at least the protection of a warrant requirement. ${ }^{115}$

Justice Harlan answered that critical question in the negative, ${ }^{116}$ and his misgivings about a facile and uncritical application of the reasonable-expectation-of-privacy test were well founded, for the phrase has indeed taken on the talismanic quality the Katz majority sought to avoid by rejecting recognition of Fourth Amendment interests based on a mechanical identification of "constitutionally protected area[s]."117 The post-Katz Court simply substituted constitutionally protected areas for those areas or places in which a defendant has a legitimate expectation of privacy, at least under the formulation adopted by the Court in Rakas. ${ }^{118}$ Ironically, the Rakas Court criticized the "legitimately on premises" test of standing it overruled as being "simply a label placed by the courts on results which have not been subjected to careful analysis." "119 And yet, Justice Rehnquist, in his opinion for the Court, failed to explain why the defendants did not have the requisite interest in a private vehicle they occupied with the owner's consent, and in which they concealed objects in the glove compartment and under the front passenger seat. ${ }^{120}$ For Justice White, the reason for this failure is simple, and he

115 White, 401 U.S. at 786 (Harlan, J., dissenting).

116 See id.

117 See Katz, 389 U.S. at 350 ("We decline to adopt this formulation of the issues. In the first place, the correct solution of Fourth Amendment problems is not necessarily promoted by incantation of the phrase 'constitutionally protected area."”).

118 See Rakas, 439 U.S. at 143, 148.

119 Id. at 148. Rakas overruled the much broader test for standing provided in Jones $v$. United States, 362 U.S. 257, 267 (1960) ("No just interest of the Government in the effective and rigorous enforcement of the criminal law will be hampered by recognizing that anyone legitimately on premises where a search occurs may challenge its legality by way of a motion to suppress, when its fruits are proposed to be used against him.").

${ }^{120}$ Rakas, 439 U.S. at 165 (White, J., dissenting) ("More importantly, how is the Court able to avoid answering the question why presence in a private place with the owner's permission is insufficient. If it is 'tautological to fall back on the notion that those expectations of privacy which are legitimate depend primarily on cases 
challenged the Court, if concerned with the costs of the exclusionary rule, to deal directly with the legitimacy of that rule itself and not reach the Court's desired outcomes by distorting Fourth Amendment doctrine and values. ${ }^{121}$

Putting aside, for the moment, Justice White's assessment that, upon deciding Rakas, the Court held "that the Fourth Amendment protects property, not people," ${ }^{122}$ what can be said with certainty some forty years after Katz was decided? Having a legitimate expectation of privacy in a house or curtilage does not necessarily require ownership of such premises, nor is an ownership interest sufficient. ${ }^{123}$ When it is a car that is searched, an ownership interest seems to be necessary, but again, not sufficient. ${ }^{124}$ And what about a public phone booth? The result in Rakas is difficult to reconcile with Katz, even as the former adopted the test of the latter (or, as this Article submits, some version of it). It is difficult to explain, in any real-world sense, how Mr. Katz had a legitimate expectation of privacy in a conversation held in a public phone booth, while Mr. Rakas did not have a legitimate expectation of privacy in the items he concealed from the public in the privately owned car of his companion. Imagine that, instead of hiding rifle shells and a sawed-off shotgun in the vehicle, Mr. Rakas entered the vehicle, shut the door, and engaged in a conversation with his companion, the owner of the car. Would the police be entitled to place a listening device on the outside of the car, without the car owner's permission, and record the conversation taking place inside? And, would Mr. Rakas even be permitted to object? Perhaps there is something more sacred about conversations than shotguns, but perhaps not. After all, just as our conversations

deciding exclusionary-rule issues in criminal cases,' then it surely must be tautological to decide that issue simply by unadorned fiat.") (internal citation omitted).

${ }^{121} \quad$ Id. at 157 .

122 Id. at 156.

123 See Minnesota v. Olson, 495 U.S. 91 (1990) (holding that overnight guests do have a legitimate expectation of privacy in their host's home, despite a lack of ownership or other property interest); Florida v. Riley, 488 U.S. 445 (1989) (holding that, although ordinarily, one has a legitimate expectation of privacy in one's curtilage, there is no such expectation with respect to aerial observation from navigable airspace); Smith v. Maryland, 442 U.S. 735 (1979) (holding that one has no legitimate expectation of privacy in the phone numbers dialed from inside one's home).

124 See Rakas, 439 U.S. 128 (1978); see also Illinois v. Caballes, 543 U.S. 405 (2005) (holding that there is no legitimate expectation of privacy implicated when a trained dog sniffs and alerts to contraband located in one's car). 
are constitutionally protected, ${ }^{125}$ so, too, can we claim a constitutional right to bear arms. ${ }^{126}$ Ignoring (as we must) the fact that the shotgun in Rakas was an instrumentality of crime, and Katz's conversation itself was unlawful, ${ }^{127}$ it seems that both Mr. Rakas and Mr. Katz would have been reasonable in their expectations that what they sought to keep private would remain so.

It is not helpful simply to say that Rakas reached the wrong result and identified the wrong standard, without discerning what the correct standard should be. For that, one must return to the majority opinion of Katz itself. Places and areas are relevant, as are the questions of ownership or other possessory interests in, and physical trespasses onto, such places and areas, and Katz did not repudiate this; it simply said that such factors should not be considered "in the abstract" 28 and that the reach of the Amendment "cannot turn upon the presence or absence of a physical intrusion into any given enclosure." ${ }^{\prime 29}$ The key to determining whether a Fourth Amendment search has occurred, and the closest the majority comes to articulating a "test" is to ask whether the government violated not an expectation of privacy, but the actual privacy upon which the defendant "justifiably relied." ${ }^{30}$ In other words, was the information or object discovered by the police otherwise hidden, would it have remained so, and would the individual seeking to keep it hidden have been entitled to believe that it would have remained so, absent some action on part of the police?

The Katz majority, while not reducing this concept to a more concrete test, did elaborate by providing that the conduct of the defendant in trying to maintain his privacy and his intent to keep the object of the government's search to himself (or, in the case of a conversation, to himself and his conversant) are relevant in determining whether the protections of the Fourth Amendment have been triggered. Justice Stewart wrote in Katz, "[w] hat a person

${ }^{125}$ See U.S. Const. amend. I ("Congress shall make no law... abridging the freedom of speech ....”).

126 See U.S. CONST. amend. II ("[T] he right of the people to keep and bear arms shall not be infringed.”); Dist. of Columbia v. Heller, 554 U.S. 570 (2008) (affirming personal right to bear arms under the Second Amendment).

${ }^{127}$ Of course, the precise contents of the glove compartment or the conversation would be unknown to law enforcement until after privacy is breached and the search, or non-search, has already occurred. Thus, such ex-post knowledge cannot play a role in determining, ex-ante, the reasonableness of defendant's expectation of privacy.

128 Katz v. United States, 389 U.S. 347, 351 (1967).

129 Id. at 353 (emphasis added).

130 Id. 
knowingly exposes to the public... is not the subject of Fourth Amendment protection. But what he seeks to preserve as private... may be constitutionally protected." ${ }^{131}$ Notice that although one seeks to preserve one's privacy, one may not ultimately be successful in doing so.

Justice Harlan's formulation of the Katz test seems to take this language as a departing point and focuses solely on the conduct and expectations of the defendant. ${ }^{132}$ A more symmetrical, and more accurate, understanding of the Katz "justifiable reliance" test also requires an examination of the government's conduct in the threshold analysis of whether a search has occurred, before turning to the government's conduct once again, if that threshold is met, to determine the ultimate issue of whether that search is reasonable. ${ }^{133}$ Modern post-Katz doctrine has focused solely on the defendant's perspective for purposes of determining the threshold question, and nowhere is this more obvious than in the standing cases, in which the defendant's relationship with the place searched is the sole criteria examined, and the second, substantive stage of determining whether police acted reasonably is never even reached.

While the Katz opinion does speak to the defendant's conduct, the government's conduct must be examined at the threshold stage as well, and this is implicit, if not explicit, in Katz. We know that Mr. Katz's conversation did not in fact remain private, but it is the method of its disclosure to government agents that made it a search. Had Mr. Katz, fully intending to keep his conversation private, shut the door to the telephone booth, but nonetheless shouted so that agents, or indeed any passersby, could hear him, then there would have been no search. In modern terms, his subjective expectation of privacy would not have been objectively reasonable. But Mr. Katz's conversation with his bookie did not come to light because it was audible by the naked ear outside the phone booth; it was revealed to government agents because of their "activities in electronically

131 Id. at 351 (internal citation omitted).

132 See White, 401 U.S. at 786 (Harlan, J., dissenting). As previously discussed, Justice Harlan himself indicated his dissatisfaction with the Court's treatment of his test, because of the concentrated focus on the defendant's expectations without any normative inquiry as to what sort of surveillance on the part of the government we should tolerate in a free society. See id.

133 For example, once it is determined that a search occurred, the Court must examine the government's conduct in conducting that search and decide whether it conformed to the requirements of the Fourth Amendment. 
listening to and recording [Mr. Katz's] words." ${ }^{134}$ In other words, if one examines and focuses on the agents' conduct (as the Katz majority did), they were not merely passing by, or even secreting themselves in a nearby bush to overhear the conversation. ${ }^{135}$ They placed a listening and recording device on the outside of the booth, and it was this conduct that made the discovery of the evidence a search and, consequently, a subject of Fourth Amendment scrutiny. ${ }^{136}$

While this analysis of the Katz's underlying facts and conclusion may seem simple, perhaps even painfully obvious, this Article seeks to illuminate what has been obscured, but nonetheless is inherent in the reasonable-expectation-of-privacy test, especially when read in conjunction with Justice Stewart's majority opinion: that an expectation of privacy on which one may justifiably rely must take into account the expectations that society harbors with respect to government conduct, which entails a normative inquiry as to how we expect, and indeed, want, our government to interact with its citizens. Such a conduct-oriented test will require careful analysis of specific facts and circumstances each time a court is called upon to determine whether or not a search has occurred, and this may impact the clarity (if any such claim can be made) of the existing regime. ${ }^{137}$ Police are

134 Katz, 389 U.S. at 353.

135 Justice Black, in dissent, points out that eavesdropping by the unaided ear, even in secret, was not unknown to the Framers. See id. at 366 (Black, J., dissenting). "There can be no doubt that the Framers were aware of this practice, and if they had desired to outlaw or restrict the use of evidence obtained by eavesdropping, I believe that they would have used the appropriate language to do so in the Fourth Amendment." Id. at 366. What Justice Black failed to acknowledge, however, is that it is much easier to protect oneself against the type of eavesdropping the Framers would have been familiar with, for example, by whispering, although this Article does not make a normative claim that we should all assume that someone is lingering outside our windows and at all times speak in hushed tones. That said, however, it is much more difficult to protect a conversation against technology that the average citizen may not be aware of, and may not realistically be able to overcome.

${ }^{136}$ The focus of this Article is on the necessity of examining governmental conduct as part of the threshold search determination. It is worth pointing out here, however, that the conduct of the government would be further examined at the second stage, the determination of reasonableness. As the Katz Court stated, the agents acted "with restraint" and did not gather any more information than would have been authorized by warrant. Id. at 356 . However, that was simply not sufficient to satisfy the demands of the Fourth Amendment, which requires a warrant before the government may conduct a search, at least in the absence of some lawful justification for the failure to acquire one. Id.

${ }^{137}$ While it is nearly impossible to make a claim that current Fourth Amendment doctrine provides an easily administrable set of rules, a categorical approach to defining searches at least establishes certain definite boundaries that police officers can follow. 
certain, for example, that they may trespass upon a suspect's land, as long it is far enough from her home, regardless of what signs she has posted or fences she has erected to keep the public off of her property. ${ }^{138}$

While there is a valid argument for providing the police with bright-line rules to guide them in their day-to-day enforcement decisions, there is also a real danger that Fourth Amendment rights are violated when individual rights are subservient to clarity and efficiency. ${ }^{139}$ The Fourth Amendment does offer a bright-line rule: a warrant is required before the government may search, but this bright line has already been dimmed by considerations to efficient law enforcement that have resulted in a myriad of exceptions to the general rule. Just as officers are required to make judgments as to whether, for example, an exigency truly exists that makes a warrant unnecessary, ${ }^{140}$ officers may make judgments as to whether their investigative activities constitute a search. It would be unfair and impractical to require police officers to make hair-splitting distinctions, but just as the conduct of the suspect (with respect to maintaining her privacy) is held to a standard of reasonableness, so too, should the conduct of the officer. Thus, police conduct is not evaluated in a vacuum, but in light of societal norms and existing law. In the context of a due process challenge to a criminal statute, the Court stated:

A criminal statute must be sufficiently definite to give notice of the required conduct to one who would avoid its penalties, and to guide the judge in its application .... But few words possess the precision of mathematical symbols, most statutes must deal with untold and unforeseen variations in factual situations, and the practical necessities of discharging the business of government inevitably limit the specificity with which legislators can spell out prohibitions. Consequently, no more than a reasonable degree of certainty can be demanded. Nor is it unfair to

138 See Oliver v. United States, 466 U.S. 170 (1984). The Court indeed eschewed a test that would be based on factual inquiries as to the height of fences and the number and nature of posted signs. Id.

139 In Robinson v. United States, 414 U.S. 218 (1973), the Court adopted a brightline approach to searches incident to lawful arrest, permitting the search of the entire person and all containers, regardless of whether the actual justifications for this exception to the warrant requirement exist, namely the danger that the arrestee will harm the officer or others, or otherwise impede law enforcement by resisting arrest or destroying evidence. See id.

140 See Warden v. Hayden, 387 U.S. 294 (1967). 
require that one who deliberately goes perilously close to an area of proscribed conduct shall take the risk that he may cross the line. ${ }^{141}$

Is it unfair to require of police officers a similar assumption of risk when police conduct violates social norms, when that risk entails very little in terms of personal consequence to the officer? After all, the police officer whose conduct crosses over the line of what is constitutionally permissible generally faces only suppression of evidence, while the defendant whose conduct has violated a criminal statute faces great personal consequences. ${ }^{142}$

Thus far, this Article has identified one of the most significant flaws in the Court's Fourth Amendment search jurisprudence: the concentrated attention on the acts of the victim and the victim's relationship with a given area to define whether the government has conducted a Fourth Amendment search. This almost exclusive focus on the victim has led to a narrow definition of Fourth Amendment searches, one that does not comport with the reality of society's expectations, is ill-equipped to protect against further encroachment against privacy, and is decidedly government-friendly. This Article has also shown, however, that Katz, even taking into account Justice Harlan's formulation of the majority's holding, does not mandate an approach that only contemplates the victim's actions and expectations, but in fact supports a more robust examination of the conduct of both victim and law enforcement in defining a search.

Although, at first blush, it may seem unlikely that the law of rape might inform the pursuit of a normatively sounder definition of a search, rape law has undergone the very transition this Article suggests is necessary in the Fourth Amendment search context: a shift from a definition of the offense that relies solely on the victim's actions and intent to one that meaningfully takes into account the conduct of the perpetrator (of the rape or of the search, as the case may be). An examination of the evolution of rape law, to which the Article now turns, including the specific reforms achieved as well as the conditions that fueled the movement for drastic change, will

\footnotetext{
141 Boyce Motor Lines v. United States, 342 U.S. 337, 340 (1952).

142 While it is true that federal officers may face damages under Bivens $v$. Six Unknown Named Agents of Fed. Bureau of Narcotics, 403 U.S. 388 (1971), and state officers may face civil suit under 42 U.S.C. \$ 1983, the doctrine of qualified immunity, established by the Court in Harlow v. Fitzgerald, 457 U.S. 800, 818 (1982), offers considerable protection to officers who may violate one's Fourth Amendment (or other constitutional or statutory) rights, as long as the rights at issue are not "clearly established" at the time of the violation. See id.
} 
reveal striking parallels to Fourth Amendment search law, as it has developed under Katz, and will illuminate the pressing need for a similar evolution in defining the search.

\section{THE EVOLUTION OF RAPE LAW: WE'VE COME A LONG WAY, BABY ${ }^{143}$}

\section{A. Rape Law Then: Helpful to Defendants, Hostile to Victims}

[Rape] is an accusation easily to be made and hard to be proved, and harder to be defended by the party accused, though never so innocent.

$$
\text { -Mathew Hale }{ }^{144}
$$

The prospect of being raped is terrifying to its potential victim, so much so that feminists conceived of rape as a method of control that "kept women off the streets, confined to their homes, and unsafe even there." 145 However, as evidenced by Sir Matthew Hale's observation, quoted above, men were also terrified of rape, not necessarily as victims, ${ }^{146}$ but as potential accusees. While the law may

143 See Highlights: Marketing Cigarettes to Women, CTRS. FOR DiSEASE CONTROL AND Prevention, http://www.cdc.gov/tobacco/data_statistics/sgr/2001/highlights /marketing (last visited Nov. 24, 2012). The phrase "We've Come a Long Way, Baby" is almost certain to conjure up images of elegantly dressed women smoking long, slender cigarettes (demonstrating how effective the Phillip Morris advertising campaign was in its day), although the exact slogan was, "You've Come a Long Way, Baby." Unfortunately, Phillip Morris was extremely successful in its approach, tapping into the burgeoning women's movement and creating the illusion that smoking was somehow linked to independence and success. See id. So successful were they, along with their competitors, that there was a significant increase in the initiation of smoking among teenaged girls, proportional to the increase in sales of cigarettes targeted specifically to women. See id. My use of a variant of the slogan is, of course, by no means meant as an endorsement of smoking. "We've Come a Long Way, Baby" is also the title of an album and song performed by Loretta Lynn, which, quite appropriately to this discussion, includes the following lines: "Up to now, I've been an object made for pleasin' you. Times have changed and I'm demanding satisfaction, too." See LoretTA Lynn, We've Come a Long Way Baby, on WE've Come A LONG WAY BABY 1978), available at http:/ / www.youtube.com/watch?v=hpHzJ0Igayo.

${ }_{144}$ Keith Burgess-Jackson, A Most Detestable Crime: New Philosophical Essays On RaPe 18 (Oxford Univ. Press, 1st ed. 1999) (quoting 1 Mathew Hale, The History of the Pleas of THE Crown 635 (1847)).

145 Patricia Smith, Social Revolution and the Persistence of Rape, in A MosT Detestable Crime: New Philosophical Essays on Rape 32, 35 (Keith Burgess-Jackson ed., Oxford Univ. Press, 1st ed. 1999).

${ }^{146}$ One reform from the common law definition of rape is to frame the offense in gender-neutral terms, allowing for the prosecution of rape (or sexual assault) committed by a perpetrator of either gender upon a victim of either gender. See, e.g., 18 PA. CONS. STAT. § 3121 (2011) (defining rape as occurring when "[a] person engages in sexual intercourse with a complainant" under proscribed circumstances) (emphasis added). For the purposes of this Article, I maintain the traditional, 
have done little to assuage the terror of women, traditional rape law acknowledged and sought to alleviate men's fear of being convicted for sexual behavior that may have crossed the line by making that line very clear and difficult to cross, and by erecting significant substantive and evidentiary barriers to conviction. Hale was absolutely correct in one respect: under traditional rape law it was indeed hard to prove that a victim of undesired sexual intercourse had, in fact, been raped.

Standing as an obstacle between perpetrator and conviction, and between victim and vindication, various characteristics of traditional rape law ensured that only the most egregious acts of sexual aggression were punishable. Blackstone defined rape as "carnal knowledge of a woman forcibly and against her will."147 Under this definition, force and nonconsent were both required elements; thus, a man who proceeded to have intercourse with a woman, even one who clearly did not consent, did not rape the woman if he did not have to resort to the use or threat of severe force to accomplish the penetration. ${ }^{148}$ State $v$. Alston provides an example of this dual requirement at work, in which the North Carolina Supreme Court overturned the conviction of a physically abusive defendant who had demanded sex from his former live-in girlfriend when she told him that she wanted to end their relationship. ${ }^{149}$ The Court had little

gender-specific approach assuming male perpetrators upon female victims, for ease of writing, for better applicability to my analogy to the Fourth Amendment, and to reflect statistical data. See Joshua Dressler, Cases and Materials on Criminal Law 387 (5th ed. 2009) [hereinafter DRESSLER, CASES AND MATERIALS] (referencing 1997 Bureau of Justice statistics indicating a 1.8 per 100 rate of victimization for women, compared to a rate lower than 0.1 for men). I do not mean in any way to imply that men are not also victims of this brutal offense or to minimize the gravity of harm to any victim, female or male. I also wish to acknowledge the important work of Professor I. Bennett Capers in raising awareness of "male rape victimization and our collective response to such victimization." I. Bennett Capers, Real Rape Too, 99 CAL. L. REv. 1259, 1262 (2011). According to a 2008 Bureau of Justice Statistics study, "more than 36,000 males age 12 and over were victims of completed rape or attempted rape ... and ... one in thirty-three men in the United States has been the victim of rape or attempted rape." Id. at 1261.

147 Blackstone, supra note 26, at 210. See also Keith Burgess-Jackson, A History of Rape Law, in A Most Detestable Crime: New Philosophical Essays on Rape 15 (Oxford Univ. Press, 1999) (tracing the history of rape law from 1900 B.C.).

${ }^{148}$ E.g., David P. Bryden, Redefining Rape, 3 Buff. CrIM. L. Rev. 317, 355 (2000); Dressler, Where We Have Been, supra note 31, at 416-17; Estrich, supra note 28, at 1105-07.

${ }^{149}$ State v. Alston, 310 N.C. 399, 402 (1984). After the victim, Cottie Brown, told the defendant that their relationship was finished, he "said that since everyone could see her but him he had a right to make love to her again." Id. The Court described their six-month sexual relationship as "consensual," despite the fact that Alston had "struck her several times throughout the relationship when she... refused to do 
difficulty reaching the conclusion that the victim, Cottie Brown, had not consented to the intercourse: she had told the defendant immediately preceding the intercourse that she was not willing to have sex with him. ${ }^{150}$ Although the intercourse was clearly "against her will," "151 Brown remained passive as Alston undressed her, "pushed apart her legs and had sexual intercourse with her" while she cried. ${ }^{152}$

The Court recognized, and then dismissed, her "general fear" of Alston because, even though her fear was justified by his prior conduct, the Court found it insufficient to prevent her resistance to that specific act of intercourse on that particular occasion and, therefore, insufficient to demonstrate Alston's use of force. ${ }^{153}$ Moreover, not only did the Court not credit Brown's general fear of Alston, based on the couple's past, but it found that the acts of grabbing her arm and threatening to "fix her face" on the very day of the alleged rape, after he accosted her at her school, telling her "she was going to miss class that day," were also too remote from the intercourse at issue to qualify as the use or threatened use of force necessary to support a rape conviction. ${ }^{154}$

The result of Alston led Professor Susan Estrich to note the paradox created by acknowledging that sex may be simultaneously without consent and without force: "In other words, the woman was not forced to engage in sex, but the sex she engaged in was against her will." ${ }^{155}$ This paradox, Professor Estrich tells us, can be expected

what he wanted," despite the fact that she often remained passive during intercourse, and even with the finding that "their consensual sexual relations involved some violence." Id. at 401.

$150 \quad I d$. at 403 .

$151 \quad$ Id. at 408 .

$152 I d$. at 403 .

$153 \quad I d$. at 409. "[A]bsent evidence that the defendant used force or threats to overcome the will of the victim to resist the sexual intercourse alleged to have been rape, such general fear was not sufficient to show that the defendant used the force required to support a conviction of rape." Id.

154 State v. Alston, 310 N.C. 399, 402 (1984).

The State did not offer substantial evidence, however, of the element of force. As we have stated, actual physical force need not be shown in order to establish force sufficient to constitute an element of the crime of rape. Threats of serious bodily harm which reasonably induce fear thereof are sufficient. In the present case there was no substantial evidence of either actual or constructive force... . This threat by the defendant and his act of grabbing Brown by the arm at the school, although they may have induced fear, appeared to have been unrelated to the act of sexual intercourse between Brown and the defendant. Id. at 408 .

155 Estrich, supra note 28, at 1111. Professor Estrich also describes another 
when force is understood in terms of the "traditional male notion of a fight.... In a fight, you hit your assailant with your fists or your elbows or your knees. In a fight, the one attacked fights back. In these terms, there was no fight in Alston. Therefore, there was no force." 156 For Estrich, physical force can be, but is generally not, understood as "the power one need not use." to use physical force to engage in intercourse with the passive, yet unwilling, Brown because she was unable to fight back: "[h]ers is the reaction of people who have already been beaten, or who never had the power to fight in the first instance." 158

If the victim does not or cannot fight back, then of course, the perpetrator does not have to resort to force, at least as force was traditionally understood. ${ }^{159}$ Therefore, as a practical matter, the prosecution would be unable to prove one of the elements of forcible rape-force-without the victim providing the impetus for the use of force against her by her resistance. This de facto element of the victim's resistance, however, does more than simply necessitate the use of the required force; it also defines the level of force that is punishable and establishes, as an evidentiary matter, another required element- the victim's lack of consent to the intercourse. ${ }^{160}$

Thus, if the woman failed to resist, absent good reason for her failure, ${ }^{161}$ the law generally (though not always, as highlighted by

unsettling North Carolina case, State v. Lester, 321 S.E.2d 166 (N.C. Ct. App. 1984) (aff'd 313 N.C. 595 (1985), but overruled by State v. Etheridge, 352 S.E.2d 673 (1987)), in which the Court of Appeals applied the Supreme Court's holding in Alston to hold that a father alleged to have raped his fifteen-year-old daughter (he was alleged to have had intercourse with all three of his daughters, and with this particular victim as early as at the age of eleven) did not, in fact, use the required force to support a conviction, even though in the past he beat the children's mother (in view of his children), his girlfriend, and his son, and threatened to kill the mother and the daughter in question. Id. The North Carolina Court of Appeals also found that the intercourse was against the victim's will, but nonetheless had this to say: "There is no evidence, however, that defendant used either actual or constructive force to accomplish the acts with which he is charged. As Alston makes clear, the victim's fear of defendant, however justified by his previous conduct, is insufficient to show that defendant forcibly raped his daughter [on the days in question]." Id. at 761 (emphasis in original).

156 Estrich, supra note 28, at 1111.

${ }^{157}$ Id. at 1115 .

$158 I d$. at 1111

159 Bryden, supra note 148 , at 356.

160 Anderson, supra note 29, at 967; Estrich, supra note 28, at 1130.

161 A woman's will to resist (and thus, the requirement for her to do so) could be overcome by sufficient threats on the part of the perpetrator, although as Alston demonstrated, such threats had to be specific to the act of intercourse at issue. See 
Professor Estrich) ${ }^{162}$ presumed that the intercourse was not against her will; in fact, the historically prevailing view was that "a truly unwilling woman would fight nearly to the death to protect her virtue." ${ }^{63}$ The victim's utmost resistance, then, served to put the man clearly on notice, thereby eliminating issues of mistake as to consent, and also identified the victim who, by risking her life to safeguard her chastity, earned the protection of the law as well. ${ }^{164}$ As for resistance and its relationship to force, a requirement of utmost resistance saved courts from the difficult task of defining precisely how much force

State v. Alston, 310 N.C. 399, 409 (1984); see also State v. Rusk, 289 Md. 230, 244 (1981) (holding that a woman's failure to resist must be a result of threats that generate fear that is "reasonably grounded"). In State v. Rusk, the Maryland Court of Appeals reinstated the conviction of the defendant, primarily based on its conclusion that the question of reasonableness of the complainant's fear was a matter for the jury. Id. In Rusk, the victim, met the defendant at a bar, gave him a ride home to an unfamiliar area, and then accompanied him to his room (first having declined his invitation) after he had taken her car keys. Id. She remained in his room while he went to the bathroom, and when he returned, he asked her to undress herself and remove his clothing as well. $I d$. The victim described what happened next:

I was really scared, because I can't describe, you know, what was said. It was more the look in his eyes; and I said, at that point-I didn't know what to say; and I said, "If I do what you want, will you let me go without killing me?" Because I didn't know, at that point, what he was going to do; and I started to cry; and when I did, he put his hands on my throat, and started lightly to choke me; and I said, "If I do what you want, will you let me go?" And he said, yes, and at that time, I proceeded to do what he wanted me to.

Rusk v. State, 43 Md. App. 476, 478-79 (1979) (en banc), rev'd, 289 Md. 230 (1981). The Court of Special Appeals reversed the defendant's conviction, finding that none of the defendant's "words or actions created in the mind of the victim a reasonable fear that if she resisted, he would have harmed her, or that faced with such resistance, he would have used force to overcome it." Id. at 484. The Court of Appeals reversed the intermediate court over a vehement dissent, arguing that defendant was more a "seducer" than a rapist, and that the truly unwilling woman must "follow the natural instinct of every proud female to resist, by more than mere words, the violation of her person .... She must make it plain that she regards such sexual acts as abhorrent and repugnant to her natural sense of pride." Id. at 255 (1981) (Murphy, J., dissenting). For Chief Judge Murphy, the fact that the defendant did not utter any specific verbal threats to physically and grievously harm the victim, coupled with the fact that he did not display or threaten to use a weapon, left him unable to "understand how a victim could participate in these sexual activities and not be willing." Id. at 257 .

${ }^{162}$ See supra note 154 and accompanying text.

163 Estrich, supra note 28, at 1130. Professor Ross recognizes the same presumption at work in the criminal procedure context, noting that consent is equated with submission to power. Ross, supra note 3, at 2-4 ("Just as rape victims were told they asked for it by wearing short dresses and not screaming for help, individuals are told they asked for it by extending their arms to be searched.").

164 Estrich, supra note 28, at 1130. 
exceeded the legally acceptable limit by demarking that limit with a bright, if not unrealistic, line drawn by the victim's response. ${ }^{165}$

In sum, under the traditional approach, if the victim did not resist vehemently, neither nonconsent nor force were proved, and therefore, the intercourse was not considered rape. Perhaps one of the most notorious examples of the utmost resistance requirement can be found in Brown v. State. ${ }^{166}$ The defendant tripped a sixteenyear-old girl (recently recovering from an episode of measles) to the ground, and forced her to engage in intercourse with him. She described her response to his attack in the following way:

I tried as hard as I could to get away. I was trying all the time to get away just as hard as I could, I was trying to get up; I pulled at the grass; I screamed as hard as I could, and he told me to shut up, and I didn't, and then he held his hand on my mouth until I was almost strangled. ${ }^{167}$

However, there were no tears in the clothing of either party, other than a one-inch tear in the victim's underwear, and no bruises or other injuries to demonstrate the "terrific resistance which the determined woman should make" and which is "essential to the crime of rape." What did the law require of this young woman before she could be called a victim of rape? According to the Wisconsin Supreme Court:

Not only must there be entire absence of mental consent, but there must be the most vehement exercise of every physical means or faculty within the woman's power to resist the penetration of her person, and this must be shown to persist until the offense is consummated. ... Except for one demand, when first seized, to "let me go," and inarticulate screams, she mentions no verbal protests .... [W] cannot conceive it possible that one whose mind and exertions had, during an encounter of this sort, been set on resistance, could or would in narrative mention nothing but escape or withdrawal. A woman's means of protection are not limited to that, but she is equipped to interpose most effective obstacles by means of hands and limbs and pelvic muscles. ${ }^{169}$

And what of the fact that there were no marks or signs of a struggle? This leads us to another feature of pre-reform rape law

See id.

166 Brown v. State, 106 N.W. 536 (Wis. 1906).

$167 \quad I d$. at 537.

$168 \quad$ Id. at 539.

$169 \quad I d$. at 538 . 
(although not of common law origin): the corroboration requirement. ${ }^{170}$ Other procedural features of pre-reform rape law included the "fresh complaint" rule, ${ }^{171}$ as well as the use of cautionary instructions, to ensure that jurors did not rush to convict without first "evaluat[ing] the testimony of a victim ... with special care in view of the emotional involvement of the witness and the difficulty of determining the truth with respect to alleged sexual activities carried out in private."172

One final procedural feature of pre-reform rape law to address here is the use of the victim's prior sexual history as a tool of cross-

${ }^{170}$ E.g., Estrich, supra note 28, at 1137. Although not a common law rule, the corroboration requirement was set out in the Model Penal Code and was, at one time, in effect in a significant number of states. See Model Penal Code $\S$ 213.6(5) (2011); Dressler, Where We Have Been, supra note 31, at 416. I remind the reader of Sir Matthew Hale's concern for the "never so innocent" party accused of rape, a concern prompted by a distrust of women generally and a fear of fabrication on the part of a woman whose dishonor may have been discovered, or whose accusation is prompted by vengeance, or who simply cannot separate her fantasies about rape from reality. Estrich, supra note 28, at 1137. Therefore, this evidentiary hurdle to conviction was based on the following rationale: "[s]ince stories of rape are frequently lies or fantasies, it is reasonable to provide that such a story, in itself, should not be enough evidence to convict a man of a crime." See id. at 1137 n.157 (quoting Corroborating Charges of Rape, 67 Colum. L. REv. 1137, 1138 (1967)). Because most rapes occur in private, without the benefit of witnesses, the victim's testimony would need to be supplemented by other corroborating evidence, such as the bruises, injuries, and other signs of struggle that were so notably absent from the body or clothing of either victim or assailant in Brown, a "situation" the court there found "well-nigh incredible." Brown, 106 N.W. at 539. Wisconsin, in fact, did not have a formal corroboration rule, but even absent such a requirement, the burden on the victim to establish that she had been raped (and had adequately resisted) was a difficult one to overcome in the absence of physical signs of a struggle. See id. "This court does not hold, with some, that, as matter of law, rape cannot be established by the uncorroborated testimony of the sufferer, but, in common with all courts, recognizes that, without such corroboration, her testimony must be most clear and convincing. Among the corroborating circumstances almost universally present in cases of actual rape are the signs and marks of the struggle upon the clothing and persons of the participants ...." Id.

171 E.g., Estrich, supra note 28, at 1139. Although the "fresh complaint" rule found its absolute form, again, in the MODEL PENAL CODE $\S 213.6(4)$ (2011) (providing that prosecution was barred unless the offense was brought to the attention of the police within three months of the occurrence, or in the case of a child under the age of 16 , within three months of a parent, guardian, or other similarly situated adult learning of the incident), at common law, delay in reporting created a compelling presumption against the victim, based on the fear of a woman's accusations being prompted by discovery of pregnancy, bitterness over the dissolution of a relationship, and even the desire to blackmail the former sexual partner. See id.

172 Model Penal Code $\$ 213.6(5)$ (2011). 
examination at trial. ${ }^{173}$ Not only might the victim be cross-examined as to her sexual past, but often testimony of third parties was introduced as well. ${ }^{174}$ The victim's prior history was thought to be relevant in two ways. First, the fact that the woman had an unchaste character cast an aspersion on her general character for truthfulness as a witness. ${ }^{175}$ Second, it demonstrated that, because she had consented to sexual intercourse on a prior occasion, she was more likely to have consented on the particular occasion alleged to be rape. ${ }^{176}$ These practices, however, went beyond simply assessing credibility and propensity, by, in effect, putting the victim on trial, causing her public humiliation, and attaching blame to her for causing her own rape. Thus, if the victim engaged in a high-risk lifestyle, by frequenting singles bars, for example, she was thought to have assumed the risk of being raped. ${ }^{177}$ And, if the victim was clothed in a sexually provocative way, she had, again, assumed the risk that the man she had so tempted would interpret her attire as willingness to be his sexual partner. ${ }^{178}$

For example, a three-man and three-woman Florida jury acquitted a man of forcible rape, after he abducted the victim, who was dressed in a lace mini-skirt without underwear, at knife-point from outside a restaurant, and repeatedly had intercourse with her during a five-hour period. The male foreman of the jury stated that " $[\mathrm{w}] \mathrm{e}$ felt

173 See, e.g., Bryden, supra note 148, at 319; Dressler, Where We Have Been, supra note 31, at 416; Estrich, supra note 28, at 1094.

174 E.g., Dressler, Where We Have Been, supra note 31, at 416.

175 E.g., id.; Klein, supra note 29, at 990.

176 E.g., Klein, supra note 29, at 990. For example, the Federal Rules of Evidence provide that, although evidence to prove "action in conformity" with one's character or character trait is generally inadmissible, such evidence may be admitted in certain limited circumstances, such as when an accused seeks to offer evidence of the character of the victim of the alleged crime. FED. R. EvID. 404(a) (2). Whereas today the ability of a defendant in a rape prosecution to offer evidence of the character of the alleged victim has been limited by the enactment of Rule 412, when the Federal Rules were first promulgated, this precise use was so typical that it merited mention in the Advisory Committee Notes as an example of the rule. See FED. R. Evid. 412 advisory committee's note (“[A]n accused may introduce pertinent evidence of the character of the victim, as in support of a claim of self-defense to a charge of homicide or consent in a case of rape."). It is this use of prior sexual history evidence-to show propensity to consent-that this Article will develop, by analogy, in the context of searches, as the Court has taken a similar approach by equating voluntary exposure of information to one party with exposure to the public at large. See infra note 322 and accompanying text.

177 Klein, supra note 29, at 991-92.

178 See Smith, supra note 145 , at 34. 
she asked for it for the way she was dressed." A female juror explained, "[s]he was obviously dressed for a good time ...."

Thus far, this examination of traditional rape law has revealed a substantive definition of rape that requires both force and nonconsent and measures the existence and sufficiency of both these elements by the existence and sufficiency of the victim's resistance against her assailant, resulting in a definition of rape that placed the burden on the victim to prevent the rape from occurring at all. ${ }^{180}$ Further, pre-reform rape law erected additional, procedural barriers to conviction in the way of a corroboration requirement, cautionary instructions, and use of prior sexual history, resulting in a regime in which the victim was in essence blamed (or at the very least severely scrutinized) for the violence perpetrated against her. ${ }^{181}$ It should not be surprising that this area of law, as this Article has briefly described it, was the target of a great deal of outrage and, ultimately, the subject of significant reform. The Article turns next to the broader criticisms and goals of the reform movement that fueled the evolution of this area of law.

\section{B. Rape Law Under Siege: The Impetus for Change}

It should not astonish the reader that the law of rape reflected such a male-oriented bias; after all, at the time of its development, women had no real influence over legal matters, even those that concerned them so directly. ${ }^{182}$ It is greatly due to efforts of feminists that the law has evolved to reflect a more balanced approach, one that seeks to ameliorate the effects of this imbalance of power between men and women. While one can conceive of this imbalance in individual terms-meaning the disparity in physical size and strength between the average man and woman, which makes it more difficult for women generally to fend off a determined perpetrator

179 Dressler, CASES AND MATERIALS, supra note 146, at 420-21 (citing Jury: Woman in Rape Case "Asked for It", ChicAgo Tribune, Oct. 6, 1989, at 11).

${ }_{180}$ See Dressler, Where We Have Been, supra note 31, at 414.

181 In developing the analogy to Fourth Amendment search law, this Article will demonstrate that the law of searches bears a striking resemblance, at a conceptual level, to the law of rape. The victim of an alleged search must also shoulder the burden of demonstrating the desire to maintain privacy (nonconsent), as well as sufficient government conduct aimed at breaching that privacy (what this Article will refer to as force), by resorting to extreme measures to preserve that privacy, the ultimate inefficacy of which often lead to the conclusion that no search has occurred. See infra Part III.

${ }^{182}$ See Dressler, Where We Have Been, supra note 31, at 410. 
(and has led many to question the wisdom of a requirement of utmost physical resistance) $)^{183}$-my focus is on the subjugation and disfavored status of women as a class.

As numerous scholars have noted, in a patriarchal system that conceived of women as property, rape was historically considered a crime against a man-more precisely a crime against the particular man, either the victim's husband or father, who benefited from control over sexual access to the victim. ${ }^{184}$ Thus, "[r]ape of virgins was a serious economic matter, with unmistakable characteristics of a crime against property. For the married victim, rape appeared as an excuse to be pleaded by a woman who would otherwise be executed for adultery." 185 Thus, women were either valuable commodities in need of protection, creating a "dual male role of predator and protector of the female prey," ${ }^{186}$ or criminal defendants, subject to the stereotype, prejudice, and distrust that adheres to most criminal defendants, including those seeking to suppress evidence found by allegedly unconstitutional means. Although, happily, women are no longer regarded as property, and adultery and fornication are generally no longer subject to criminal prosecution, ${ }^{187}$ the perception of the complaining witness in a rape prosecution as being herself on trial has persisted. ${ }^{18}$

183 See infra text accompanying note 202.

184 See, e.g., Bryden, supra note 148, at 362 (citing Susan Brownmiller, Against OuR WiLl: Men, WOMEN AND RAPE 18 (1975)); Smith, supra note 145, at 32-33.

185 Donald A. Dripps, Beyond Rape: An Essay on the Difference Between the Presence of Force and the Absence of Consent, 92 Colum. L. Rev. 1780, 1781 (1992); see also Smith, supra note 145, at 33 ("[W] omen were viewed more or less like valuable livestock or perhaps uniquely prized possessions. Women, especially virgins, were very valuable property.").

186 Smith, supra note 145 , at 33.

187 While adultery and fornication are still included in certain state criminal codes, these crimes are rarely prosecuted, and, indeed, after the United States Supreme Court's decision in Lawrence v. Texas, 539 U.S. 558 (2003), which invalidated Texas's sodomy law, fornication laws (and likely adultery laws as well), if challenged, will not withstand constitutional scrutiny. See Joanna Grossman, The Virginia Supreme Court Strikes Down the State's Fornication Law, Indicating that Other States' Antiquated Laws Will Fall if Challenged, FindLAw (Jan. 25, 2005), http://writ.news.findlaw.com/grossman/20050125.html (discussing the Virginia Supreme Court's invalidation of a statute criminalizing fornication, and for an analysis of the probable effect of Lawrence $v$. Texas on a variety of other criminal statutes involving consensual sexual activity).

188 See, e.g., Estrich, supra note 28, at 1099-1100. In State v. Rusk, discussed above, see supra note 161, Judge Cole, in his dissent, expressed his dissatisfaction with the majority's decision in terms that strongly reflect this mindset of the victim becoming herself the accused by virtue of her bringing forward a complaint. State v. Rusk, 424 A.2d 720, 733 (Md. 1981) (Cole, J., dissenting) (asserting that in affirming the 
Ironically-but perhaps not surprisingly, considering the parameters under which it developed-the law of rape, while purporting to limit male sexual access to women, achieved the opposite. If the goal of criminalizing rape was to "correct the existing imbalance in sexual power... [by] constrain[ing] male sexual autonomy," ${ }^{189}$ traditional rape law, in practice, with its requirement of physical resistance on the part of the victim, instead maintained a system under which males were ensured extensive access to women and only the most extreme uses of violence were punished. ${ }^{190}$ After all, as Susan Estrich points out, the law of rape reflected a male perspective and imposed male standards of behavior on female victims. ${ }^{191}$ In other words, the law of rape "has reflected, legitimized and enforced a view of sex and women which celebrates male aggressiveness and punishes female passivity." ${ }^{192}$ Thus, under a traditional approach, men are permitted, if not expected, to respond to some level of resistance (saying no, for example) with more persistence and aggression, ${ }^{193}$ and the woman is forced to assume the guilt for sexual intercourse that occurs in the absence of some ideal level of resistance that she may not realistically be able to achieve. ${ }^{194}$

While traditional rape law, according to critics, did much to ensure the sexual autonomy of men, women did not enjoy a similar freedom of choice. In fact, the sexual autonomy of women was discouraged, certainly if one conceives of autonomy as the ability to say yes as well as the ability to say no. Professor Coughlin, however, cautions against the implication that men were always granted unlimited sexual license, proposing that the development of rape law

conviction, " $[\mathrm{t}]$ he majority today ... declares the innocence of an at best distraught young woman."). Indeed, the court below, which had reversed the defendant's conviction, began its discussion by describing the victim as a young mother, separated but not divorced, who left her two-year-old son with her mother to attend a high school reunion with a friend and go "bar hopping." See Rusk v. State, 406 A.2d 624, 625 (Md. Ct. Spec. App. 1979).

${ }^{189}$ Coughlin, supra note 28 , at 5 .

190 See id.; Estrich, supra note 28, at 1122.

191 Estrich, supra note 28, at 1091 ("It is 'boys' rules' applied to a boys' fight.”).

$192 \quad I d$. at 1092 (discussing "non-traditional" rapes, meaning those that occur "not [in] an alley but a bedroom").

193 Coughlin, supra note 28, at 5 ("Rape law thus instructs men that they are free to ignore a woman's verbal protests and even to construe such protests as expressing her agreement to participate.").

${ }^{194}$ Anderson, supra note 29, at 957 (arguing that even though the standard of resistance has been lowered over time, whichever level of resistance is required by the woman still "conceptualizes resistance as a model of exemplary action against which a real woman's actions under the extreme stress of sexual attack are judged"). 
was inextricably connected with the Puritan prohibitions, applicable to both sexes, against fornication and adultery. ${ }^{195}$ Understood this way, the burden on the alleged victim of a rape was akin to the hurdle of any defendant asserting duress as a defense to a criminal charge, and if she were to fail in her defense, presumably both parties to the consensual (but nonetheless illegally extramarital) intercourse would be punished. ${ }^{196}$

Yet, putting aside fornication prosecutions, the stigma attached to the woman engaging in consensual intercourse was, and to some extent has remained, disproportionate to that suffered by a man exercising the same freedom. In 1838, Judge Cowen, upholding the admissibility of prior sexual history as relevant to sexual propensity in People v. Abbot, ${ }^{197}$ asked,

[A]re we to be told ... that the triers should be advised to make no distinction in their minds between the virgin and a tenant of the stew? Between one who would prefer death to pollution, and another who, incited by lust and lucre, daily offers her person to the indiscriminate embraces of the other sex? $?^{198}$

195 See Coughlin, supra note 28, at 10. In fact, Professor Coughlin points to historical data indicating that, in the latter part of the seventeenth century, and for the greater part of the eighteenth, fornication was prosecuted in county court to a greater extent than any other category of criminal case, and, more importantly, prosecuted quite even-handedly. Id. at 43 (quoting Cornelia Hughes DaYTon, WOMEN BEFORE THE BAR: GeNDER, LAW, AND SOCIETY IN CONNECTICUT 160 (1995)). That said, however, Professor Coughlin also notes that despite the appearance of even-handed treatment, the ultimate goal of most of these prosecutions was to force the parties into marriage, "an institution founded explicitly on the subordination of women to men," and further, that the law of adultery itself reflected a "sexual double standard on its face," because, at least in Connecticut, adultery was defined as being committed with a married woman, leaving married men legally free to engage in extramarital sex as long as their partners were unmarried. See id. at 44-45 (citing DAYTON, supra, at 114-15, 173).

196 Coughlin, supra note 28, at 42 . Generally speaking, the common law defense of duress required that the defendant demonstrate the following:

(1) another person threatened to kill or grievously injure the actor or a third party... unless she committed the offense; (2) the actor reasonably believed that the threat was genuine; (3) the threat was 'present, imminent, and impending' at the time of the criminal act; (4) there was no reasonable escape from the threat except through compliance with the demands of the coercer; and (5) the actor was not at fault in exposing herself to the threat.

DRESSLER, UNDERSTANDING CRIMINAL LAW, supra note 27, at § 23.01.

19719 Wend. 192 (N.Y. Sup. Ct. 1838).

198 Id. at 195. Judge Cowen continues, "And will you not more readily infer assent in the practiced Messalina, in loose attire, than in the reserved and virtuous Lucretia?" Id. 
And, while it was entirely proper to use prior sexual history to attack a woman's credibility as a witness, the Supreme Court of Missouri, in 1895, disallowed the use of similar evidence to attack a man's credibility, stating,

It is a matter of common knowledge that the bad character of a man for chastity does not even in the remotest degree affect his character for truth, when based upon that alone, while it does that of a woman. It is no compliment to a woman to measure her character for truth by the same standard that you do that of a man's predicated upon character for chastity. ${ }^{199}$

Of course, attitudes and mores have changed and today's world bears little resemblance to the one experienced by the Puritans. Yet, Professor Coughlin observes that " $[\mathrm{t}]$ he problem for women today is that we seem to inhabit neither of these two worlds; rather, we live in a world that combines the worst features of both." ${ }^{200}$ While adultery and fornication, if even still included in criminal codes, are rarely prosecuted, ${ }^{201}$ the substantive law of rape still places a heavy burden on women to prove their innocence of one of these offenses. ${ }^{202}$ Further, while Professor Coughlin urges doctrinal changes to eliminate the dilemma faced by rape complainants— that their claim of being raped also serves as an admission of guilt-she concedes that doctrinal solutions alone are inadequate to eliminate this prejudice against women as long as social beliefs and conventions condemn sexual activity by women, with such condemnation being manifested through jury verdicts in rape trials. ${ }^{203}$

Professor Patricia Smith further explores the sexual role of women, noting the inconsistency of public attitudes, particularly in the 1950 s, that condemned sexual activity on the part of women while nonetheless promoting a view of women as sex objects. ${ }^{204}$ Thus, according to Professor Smith, "women were supposed to be seductive teasers who love sex themselves but somehow magically remain

199 State v. Sibley, 131 Mo. 519, 132 Mo. 102, 171 (1895). The Court continues by noting how many "great and noble men," including Lord Byron, had a "weakness ... for sexual pleasure." Id.

200 Coughlin, supra note 28, at 45.

201 See supra note 187.

202 Coughlin, supra note 28, at 45. I remind the reader of Judge Cole's perception of the complainant, and of his disapproval of the majority's decision to uphold the defendant's conviction, in State v. Rusk, 424 A.2d 720 (Md. 1981). See supra text accompanying note 188 .

203 Coughlin, supra note 28 , at $45-46$.

204 Smith, supra note 145, at 35. 
pure." ${ }^{205}$ At the same time, of course, women had to be careful not to cross the line and tempt too much, as this would be seen as having provoked the sexual encounter, or, indeed, be construed as consent. ${ }^{206}$ Taking into account this dual role of women as seductresses who should nonetheless remain pure, coupled with a distrust of women's judgment and credibility, it is not surprising to read in a 1966 student note, published in the Stanford Law Review, that a high resistance standard is necessary, as a matter of fairness to those accused of rape, to ensure that the woman who is ambivalent about sex, or indeed may be "meaning 'yes, yes, yes" despite saying, "'no, no, no," is truly withholding consent at the time of the intercourse rather than struggling with "moralistic afterthoughts."

The various critiques briefly sketched above describe the law of rape as having a male-oriented bias, and as reflecting the imbalance of power between men and women at the time of its development. While, according to feminist critics, the substantive definition of rape ensured men broad sexual access to women, effectively promoting male sexual autonomy while simultaneously restricting female sexual liberty, the practice of rape facilitated male control over all aspects of women's lives by creating "an oppressive system in which the production of fear has served to maintain women in a condition of terror." ${ }^{208}$ As mentioned above, men undertook the dual roles of protector and predator, and women depended for their safety on the very class of individuals that they were taught to fear. Protection, however, be it from the law or from men, came at a heavy price-"the price of restriction." ${ }^{209}$ The woman who asserted her independence too vigorously was considered fair game. ${ }^{210}$

$205 I d$.

206 Id at 34

207 Roger B. Dworkin, Note, The Resistance Standard in Rape Legislation, 18 STAN. L. REv. 680, 682, 685 (1966) (quoted in Estrich, supra note 28, at 1128). Professor Estrich quotes another student note, one that was quite influential, espousing the view that not only do women lie, but that even a "normal girl" may be ambivalent with regard to her own sexual desires and, further, that "a woman's need for sexual satisfaction may lead to the unconscious desire for forceful penetration, the coercion serving neatly to avoid the guilt feelings which might arise after willing participation." Note, Forcible and Statutory Rape: an Exploration of the Operation and Objectives of the Consent Standard, 62 YALE L.J. 55, 67-68 (1952) (quoted in Estrich, supra note 28, at 1129).

208 Jeffrey A. Gauthier, Consent, Coercion, and Sexual Autonomy, in A MosT Detestable Crime: New Philosophical Essays on Rape 71, 73 (Keith Burgess-Jackson ed., Oxford Univ. Press, 1st ed. 1999).

209 Smith, supra note 145 , at 34.

210 Id. 
With these broad critiques in mind, reformers sought to achieve significant changes in the law of rape to eliminate the inequality between men and women, improve male behavior, and promote women's sexual autonomy. This Article later argues that these goals-achieving balance, improving behavior, and fostering autonomy-are highly relevant in shaping Fourth Amendment doctrine, in so much as that Amendment was designed to regulate the government's power over its citizens and to support the liberty and self-determination of a free people. As many of the broader critiques of traditional rape law find perhaps unexpected parallels in the criminal procedure context, ${ }^{211}$ so too can the specific reforms achieved and proposed by rape law reformers illuminate the efforts of scholars advocating for change in Fourth Amendment doctrine. Before turning to the Fourth Amendment, however, the next section of this Article highlights the particular rape law reforms that, by analogy, are most useful to developing the more balanced approach to Fourth Amendment searches that is the subject of Part IV of this Article.

\section{Rape Law Now: Some Welcome Victories}

Perhaps the most universal reform achieved in the law of rape has been the abolition-or, at the very least, the significant softening - of the resistance requirement, in no small part due to the assertions of reformers that resistance to rape was dangerous and increased the likelihood of serious injury. ${ }^{212}$ No jurisdiction today requires resistance to the utmost; in fact, many states have eliminated any requirement of physical resistance from their statutes, either by removing any reference to resistance or by expressly stating that resistance is not required. ${ }^{213}$ A few state statutes, however, continue to

211 In the criminal procedure context, victims of police misconduct, especially the poor and minorities, face the same imbalance of power, both politically and in a dayto-day real sense. Search doctrine is geared towards granting the government broad access to evidence of wrongdoing while permitting police to use their power and discretion to maintain control and inhibit individual autonomy in the very communities being policed, creating, I argue, a similar dual role for the police of predator and protector. See infra Part III.B.

${ }^{212}$ Anderson, supra note 29, at 968. Professor Anderson critically evaluates the empirical studies on which reformers based their claims that resistance should be discouraged and presents arguments in favor of encouraging resistance, ultimately advocating that any resistance, either physical or verbal, should be sufficient to demonstrate nonconsent and force. See id.

213 See Bryden, supra note 148, at 358 n.161 (providing examples of statutes that have been amended to remove reference to resistance, or to expressly state that victims do not need to resist an attack). 
refer to some level of resistance, requiring the victim to offer, for example, reasonable or earnest resistance. ${ }^{214}$ Further, even if a statute is silent as to resistance, as long as courts must define force or determine whether there is sufficient evidence of nonconsent (or both), resistance remains a de facto requirement to some degree..$^{215}$ Thus, even with the elimination of a formal resistance requirement, "courts today often evaluate a woman's actions in the same way as they did when resistance was required." ${ }^{216}$ In fact, Professor Anderson argues that regardless of the required level of resistance, women's conduct is still held to some ideal standard of behavior that may be difficult to achieve. ${ }^{217}$

As previously stated, the focus of this Article is not to provide a comprehensive survey of the current status of the resistance requirement in statutory or common law throughout American jurisdictions, ${ }^{218}$ nor does this Article aim to provide a normative critique of the various approaches to resistance with respect to their effectiveness as rape law reforms. It suffices to simply make the very modest normative claim that a requirement of utmost resistance placed an unfair and unrealistic burden on the victim of an alleged

214 See id. (providing examples of statutes that require some level of resistance, such as reasonable or earnest resistance, or such resistance as would communicate nonconsent).

${ }^{215}$ See id. at 358-59; see also Anderson, supra note 29, at 968 ("Whether a state rape statute codifies an utmost, earnest, or reasonable resistance requirement, or no resistance requirement at all, for many courts, a woman's resistance still determines whether she consented and whether the man used force against her."). Virginia law, for example, affirmatively states that resistance is not required: "The Commonwealth need not demonstrate that the complaining witness cried out or physically resisted the accused ... but the absence of such resistance may be considered when relevant to show that the act alleged was not against the will of the complaining witness." VA. CODE ANN. § 18.2-67.6 (2011). Thus, although resistance is not technically required, it is still relevant: "The Commonwealth still must prove that the assault was against the victim's will. The statute merely allows the defendant to use lack of resistance to buttress his consent defense.” Farish v. Virginia, 346 S.E.2d 736, 739 (Va. Ct. App. 1986). Pennsylvania's sexual offense provisions also expressly provide that resistance is not required, although also stating that the defendant is not prohibited "from introducing evidence that the alleged victim consented to the conduct in question." 18 PA. CONS. STAT. $\$ 3107$ (2011). In addition, rape is defined as sexual intercourse accomplished, in relevant part, by "forcible compulsion," or by "threat of forcible compulsion that would prevent resistance by a person of reasonable resolution." Id. $\S 3121$. Thus, even though resistance is not required, the level of threat sufficient to trigger the offense is based on the assumption of a woman's resistance, the absence of which can also be used to show consent. 18 PA. CONS. STAT. $\$ \$ 3107,3121$ (2011).

216 Anderson, supra note 29, at 967.

217 See id. at 965.

218 See Klein, supra note 29, for a thorough treatment of the evolution of rape law. 
rape, in terms of both what was expected of her to prevent the intercourse in the first place, or, if ultimately unsuccessful in her selfprotection, to receive vindication in a court of law. The advances achieved by rape law reformers in this area constitute a welcome victory.

Looking ahead for a moment, this Article will demonstrate that victims of alleged searches currently also bear an "utmost resistance" requirement, with a corresponding expectation that onerous measures be taken to prevent the search in the first place, and a similar difficulty of successfully claiming that a Fourth Amendment search even occurred if the victim's efforts to maintain privacy ultimately fell short. ${ }^{219}$ As this Article does not propose to completely eliminate a "resistance" requirement in the Fourth Amendment context, but argues for something akin to a "reasonable resistance" requirement as best suited to establishing the proper balance between citizen and government, it is helpful to briefly highlight that standard here before addressing other relevant changes in the law of rape.

Missouri, for example, criminalizes forcible rape, defined as "sexual intercourse with another person by the use of forcible compulsion." ${ }^{220}$ Forcible compulsion is further defined, in relevant part, as "[p] hysical force that overcomes reasonable resistance., ${ }^{221}$ To clarify the magnitude of force required to qualify as forcible compulsion, the Missouri Court of Appeals provided the following guidance:

The totality of the circumstances determines whether this was physical force which would overcome reasonable resistance. Reasonableness is that which is "suitable under the circumstances." Such circumstances in this context would include the ages of the victim and the accused; the atmosphere and setting of the incident; the extent to which the accused was in a position of authority, domination and control over the victim; and whether the victim was under duress. ${ }^{222}$

219 See infra Part IV

220 Mo. ANN. STAT. $\$ 566.030$ (West 2011).

221 Mo. ANN. STAT. \$ 556.061(12) (West 2011).

222 State v. Kilmartin, 904 S.W.2d 370, 374 (Mo. Ct. App. 1995) (internal citation omitted); see also Jones v. State, 682 P.2d 757, 759 (Okla. Crim. App. 1984) ("In Oklahoma, a woman threatened by rape is not required to resist to the uttermost; instead, she is not required to do more than her age, strength, and surrounding circumstances make reasonable.”). 
Resistance may also come into play when the offense is framed in terms of the victim's nonconsent, as it is in Delaware. ${ }^{223}$ The Delaware legislature chose to define "without consent" in terms of the defendant compelling the victim, by various means, to submit; however, the victim's resistance is still required in order to show that she was indeed compelled: "It is not required that the victim resist ... to the utmost, or to resist if resistance would be futile or foolhardy, but the victim need resist only to the extent that it is reasonably necessary to make the victim's refusal to consent known to the defendant." ${ }^{24}$ Both of these approaches to reasonableness of resistance-based on an analysis of the totality of the circumstances to determine what is realistically feasible for the victim, and as a measure of resistance that reasonably conveys the victim's nonconsent, are, I argue, not only appropriate, but in fact called for in the search context as well.

Another reform to rape law that has been urged involves the elimination of force and nonconsent as jointly required elements of rape; in other words, some scholars advocate that either one or the other should be required, but not both. ${ }^{225}$ Regardless, however, of which element is eliminated from the formal definition of rape, courts will most likely still continue to require the woman to demonstrate, through some ideal standard of conduct, either the force or the lack of consent, resulting in the continued vitality of the resistance requirement. ${ }^{226}$ For this reason, Professor Anderson states that "force and nonconsent... are not neatly separable."227 Therefore, this particular proposed reform will have little practical effect unless the conduct that will qualify legally as sufficient resistance is broadened to reflect how women really resist (thus

223 See DEL. CRIM. CODE $§ 773$ (2011) (defining rape, in relevant part, as sexual intercourse "without the victim's consent").

${ }^{224} I d . \S 761(\mathrm{j})(1)$.

225 See Anderson, supra note 29, at 1001-02. Professor Anderson references various statutory approaches, some providing only that the intercourse be forcible in the definition of the offense (although providing that consent is a defense), others defining the offense in terms of nonconsent, and still others that continue to require both force and nonconsent as elements, concluding that despite these formal differences, most jurisdictions in practice still require both in order to prove that a rape occurred. See id. at 1000-01 nn.280-84 and accompanying text.

226 See id. at $1005-07$.

$227 I d$. at 1005 . For example, at first glance, the Model Penal Code's definition of rape seems to focus on the actor, in that rape is defined, in pertinent part, as intercourse wherein the man "compels" the woman (other than his wife) to submit either by force or serious threat. See Model Penal Code $\$ 213.1$ (2011). However, implicit in "compelling" a woman is the fact that she is not consenting. 
recognizing verbal protests as resistance) ${ }^{228}$ Additionally, regardless of which approach is taken, neither will be meaningful unless the focus on the perpetrator's conduct (if that is the touchstone of the offense) reflects an expansive notion of force, or, alternatively, the focus on the victim's state of mind reflects an expansive notion of what constitutes nonconsent. ${ }^{229}$

Although this Article argues that in defining a Fourth Amendment search, both the force used by police and the consent or nonconsent (as demonstrated by the conduct) of the victim of a search are relevant, ${ }^{230}$ it is beneficial to explore both of these approaches-defining rape in terms of force used by the perpetrator, on the one hand, and defining rape in terms of the victim's nonconsent, on the other-in order to uncover the reasoning underlying each approach, which will in turn illuminate the analogy to the criminal procedure context. Those reformers who advocate force as the sole barometer of whether a rape has occurred seek to shift scrutiny from the victim's conduct and state of mind to that of the actor. ${ }^{231}$ Proponents of this approach encourage an understanding of rape as a crime of violence, rather than as a purely sexual crime, thus aligning rape conceptually with assault and battery. ${ }^{232}$ There is, however, an additional reason to focus on force

228 See Anderson, supra note 29, at 1007.

229 See Estrich, supra note 28, at 1133. Pennsylvania, for example, classifies rape as sexual intercourse by "forcible compulsion" 18 PA. CONS. STAT. $\$ 3121$ (2011), which is broadly defined as "[c] ompulsion by use of physical, intellectual, moral, emotional or psychological force, either express or implied.” Id. $\$ 3101$.

See infra Part IV.

231 See Anderson, supra note 29, at 1005. However, as Professor Anderson notes, force and nonconsent are difficult to separate; in many jurisdictions which statutes criminalize forcible intercourse without mention of consent, courts nonetheless recognize consent as a defense. $I d$. at 1000. The State of Washington, for example, criminalizes intercourse by means of forcible compulsion, defined as "physical force which overcomes resistance" or a threat that induces fear of injury or kidnapping, but, pursuant to case law, the victim's consent is an affirmative defense that the defendant shoulders the burden to prove by a preponderance of the evidence. See WASH. REv. CODE ANN. §§ A9A.44.050, A9A.44.010(6) (West 2011); see also State v. Camera, 781 P.2d 483, 485-88 (Wash. 1989) (reasoning that placing the burden of proving consent on the defendant was consistent with legislative intent and also constitutionally permissible, as this did not relieve the prosecution of its burden of proving every element of the offense, including forcible compulsion).

${ }^{232}$ See, e.g., State of New Jersey in re M.T.S., 129 N.J. 422, 437-38 (1992) ("Reformers criticized the conception of rape as a distinctly sexual crime rather than a crime of violence .... Critics of rape law agreed that the focus of the crime should be shifted ... to its forceful and assaultive, rather than sexual, character."). In fact, one significant reform in the law of rape is a change in the name of the offense; for example, statutes may prohibit "sexual assault" rather than rape, which serves to 
rather than nonconsent, as expressed by Professor Catherine MacKinnon and others: consent should be irrelevant where that consent is obtained "under conditions of patriarchy." words, consent that is not given under conditions of equality is not really consent at all. ${ }^{234}$

In contrast, those reformers who propose that the victim's nonconsent should be the critical focal point emphasize autonomy and freedom of choice as the primary values to be protected. ${ }^{235}$ This consent-based approach has taken various forms: for some reformers, a rape has occurred if the actor has intercourse with the victim over her specific objection while others go further, criminalizing intercourse in the absence of the woman's affirmative consent. ${ }^{236}$ Perhaps the most controversial example of the affirmative consent approach is the New Jersey Supreme Court's unanimous decision in State in re M.T.S. ${ }^{237}$ The Court, in interpreting a statute that defined sexual assault as involving the use of "physical force or coercion," turned to the history of rape reform in order to determine the legislative intent behind the statute, which had been in no small part promulgated by the National Organization of Women National Taskforce on Rape. ${ }^{239}$ Then, despite the statute's requirement of "physical force or coercion," the Court held that

any act of sexual penetration engaged in by the defendant without the affirmative and freely-given permission of the victim ... constitutes the offense of sexual assault. Therefore, physical force in excess of that inherent in the

emphasize the violent nature of the offense. See Dressler, Understanding Criminal LAW, supra note 27 , at $\$ 33.01$ n.16.

233 Anderson, supra note 29, at 1004.

234 This is a powerful argument in the criminal procedure context as well, and many have argued that the Court, in its enthusiastic approval of consent searches, does not have a realistic understanding of consent or the power imbalance between the citizen and the police officer that comes to bear on a suspect's decision to cooperate. See, e.g., Robert V. Ward, Consenting to a Search and Seizure in Poor and Minority Neighborhoods: No Place for a "Reasonable Person," 36 How. L.J. 239 (1993). Professor Ross, to illustrate this point, discusses scholarship regarding the power imbalance between citizen and police, role-conditioning, and race as factors that act upon an individual's ability to freely choose or withhold consent during interactions with police. Ross, supra note 3, at 24-30.

${ }_{235}$ See Anderson, supra note 29, at 1002-03.

236 Id at 1002; see also Klein, supra note 29, at 1004-14 (discussing both the affirmative consent and the "no means no" models).

237 M.T.S., 129 N.J. at 422.

238 N.J. STAT. ANN. § 2C:14-2c(1) (2012).

239 M.T.S., 129 N.J. at $430-40$. 
act of sexual penetration is not required for such penetration to be unlawful. The definition of "physical force" is satisfied . . . if the defendant applies any amount of force against another person in the absence of what a reasonable person would believe to be affirmative and freely-given permission to the act of sexual penetration. ${ }^{240}$

Thus, the New Jersey Supreme Court virtually eliminated force from the definition of sexual assault. However, a focus on autonomy and freedom of choice does not necessarily imply that force is irrelevant. If autonomy is understood as freedom to "define all of the limits of permissible sex," which would also include freedom to engage in forcible intercourse if so desired, then rape can be viewed as "the denial of that freedom." recommends that autonomy, as a primary interest to be protected, should take "center stage," proposing that improper interferences with the exercise of autonomy, or ability to freely choose, including the use or threat of physical force as well as certain nonviolent means of coercion, should be criminalized. ${ }^{243}$ This shift in emphasis may result in the recognition that the use of nonforcible coercion may be egregious enough to warrant criminal punishment, or may lead to a broader understanding of force, aptly described by Professor Estrich, as "the power one need not use." ${ }^{244}$ In either case, a focus on the victim's autonomy may eventually lead to vindication for those victims, traditionally beyond the law's protection, who have "agreed" to intercourse under conditions of deception, ${ }^{245}$ fraud, extortion,

\footnotetext{
${ }^{240} I d$. at 444. As of 2008, two state legislatures, Wisconsin and Washington, had adopted the affirmative consent model. See Klein, supra note 29, at 1007.

Estrich, supra note 28, at 1132.

242 $I d$

243 Stephen J. Schulhofer, Taking Sexual Autonomy Seriously: Rape Law and Beyond,
} 11 LAW \& PHIL. 35, 65 (1992). Professor Schulhofer proposes the creation of two offenses prohibiting such interferences with autonomy. Rape would be defined in terms of forcible intercourse (including the threat of violence), while a new offense of "sexual abuse" or "sexual misconduct" (or some variant that would emphasize the nonforcible nature of the means used to obtain the intercourse) would punish nonviolent constraints on a woman's free choice. See id. Although Professor Schulhofer uses the term "nonviolent" in accordance with traditionally held conception of the "real" rape, described by Professor Estrich as the type of situation in which a "stranger puts a gun to the head of his victim, threatens to kill her or beats her, and then engages in intercourse," it is imperative to stress that any unconsented to intercourse is inherently violent and physically painful to the victim. Estrich, supra note 28 , at 1092 .

244 Estrich, supra note 28, at 1115.

245 For example, a California court dismissed a charge of rape against a man who convinced the victim that, other than submitting to an extremely painful and 
abuse of professional authority or economic power, and other such interferences with a victim's meaningful choice. ${ }^{246}$

While it is extremely difficult and beyond the scope of this Article to define which of these coercive interferences merit criminal sanctions, Professor Schulhofer provides an analytical framework that lends itself easily to the task, still to come, of defining a Fourth Amendment search. At the outset, sexual autonomy, meaning the right to control access to one's body under conditions conducive to meaningful choice, must be recognized as a protected value independent of the interest in being free from violence. ${ }^{247}$ Once the right of autonomy is recognized, the important questions in shaping reform become "whether the preconditions for meaningful choice are present and whether behavior that may interfere with meaningful choice has adequate social justification." ${ }^{248}$ In other words, should society tolerate the behavior in question? ${ }^{249}$

As in the search context, trying to differentiate lawful from unlawful constraints on autonomy will involve delineating socially tolerable boundaries. ${ }^{250}$ In drawing those boundaries, it is critical to understand the value of autonomy as necessary to the enjoyment of the freedom, security, and dignity that are components of our personhood. ${ }^{251}$ Autonomy can be understood in two dimensions: (1) the moral and intellectual autonomy, exemplified by the capacity to make unconstrained choices, that serves to express personal preferences; and (2) autonomy in the physical sense, asserted to preserve bodily integrity. ${ }^{252}$ Both these dimensions of autonomy are, of course, threatened when an individual is coerced or compelled to engage in sexual intercourse.

prohibitively expensive surgical procedure, the only way to treat a serious, lifethreatening disease was to engage in sexual intercourse with "an anonymous donor who had been injected with a serum which would cure the disease." Boro v. Superior Court, 163 Cal. App. 3d 1224 (1985). In response to this decision, the California legislature amended its criminal code to include a provision penalizing the procurement of consent to intercourse by "false or fraudulent representation or pretense that is made with the intent to create fear." See CAL. PEnAl Code $§ 266 \mathrm{c}$ (West 2012).

246 See Schulhofer, supra note 243, at 65-93 for a discussion of the complexities in determining the desirable scope of legal protection against these and other forms of nonforcible coercion.

247 Id. at 68 .

$248 I d$.

249 Id.

250 Id.

251 See id. at 71.

252 Schulhofer, supra note 243 , at 71. 
If autonomy is taken seriously, as the title of Professor Schulhofer's article urges, and sexual offenses are perceived more as offenses against autonomy rather than offenses involving physical violence, then an affirmative consent model is warranted. ${ }^{253}$ The traditional focus on rape as a crime of violence has led to an overly generous understanding of consent, in that the law has required a clear demonstration of nonconsent to an act that the victim finds abhorrent, thereby in effect equating ambivalence or silence with consent. $^{254}$ Once the focus shifts to autonomy, the argument can more readily be made (and accepted) for requiring the same standard of consent for all serious bodily intrusions; thus, as surgery or any invasive medical procedure requires affirmative consent (and consent is not presumed from a patient's silence or ambivalent feelings towards the procedure), so should intrusions of a sexual nature. ${ }^{255}$

There may be yet another, more pernicious, reason behind the different standards of consent applied to sexual versus other bodily intrusions, other than the perception of rape as a crime of violence rather than an offense against autonomy. In the context of undesired sex, as opposed to an undesired medical procedure, there may still be lurking some notion of male entitlement to sex, as a vestige of the patriarchal system in which sexual access was a commodity belonging not to the woman, but to whichever man had legal control over her. If indeed there is this lingering attitude that men are in some way justified in asserting a claim to sex, ${ }^{256}$ then the

253 See id. at 77.

254 Id. at 76. Under this approach, the sleeping or unconscious woman is protected because she does not have the opportunity to say no, the assumption remaining being that if a woman is able to object, but fails to do so, she is a willing partner to the intercourse. See id. at 72. Another possible explanation for this assumption is that sexual intimacy is often a consensual act, desired by both parties. Thus, there may be an operational presumption of consent that is absent, for example, when a robber demands one's wallet, or, as relevant to this Article, when police search one's home, person, or belongings for evidence.

255 Id. at 74-75. Professor Schulhofer illustrates his argument effectively by telling the "parable" of the athlete hesitating to decide whether or not to go through with surgery, and the impatient surgeon who, tired of waiting for a yes, "just does it" in the absence of a no. Id.

256 While it would certainly overstate the argument of this Article to imply that society recognizes any actual right to or privilege of sexual access for men, the fact that it remains common to blame the victim for her rape, whether because of her attire, her actions, the company she chose, or simply because she placed herself in harm's way, and the fact that juries still acquit defendants because victims "asked for it," demonstrates the public's willingness to accept some level of male entitlement to sex. See supra text accompanying notes 176-177. 
law, even if acknowledging the woman's right of autonomy, nevertheless may place a burden on her to assert her interest in that right as against the countervailing interest of the man who desires the sexual intercourse. In contrast, there is no countervailing entitlement, actual or perceived, vested in the surgeon (to use Professor Schulhofer's example) ${ }^{257}$ who wishes to perform a procedure; therefore, the only interest at stake is that of the patient. With no competing interest to balance against the patient's autonomy, it follows logic to require greater certainty with respect to consent, in the way of affirmative permission, before the surgeon is permitted to proceed. This possible explanation, or partial explanation, of why the affirmative consent model is not more widely accepted in the rape context is, of course, based on the prevalence and durability of outdated attitudes regarding male and female sexual roles and behavior-attitudes that should, and hopefully will, dissipate with time.

Before returning once again to the primary objective of this Article, applying the lessons of rape reform to the task of creating a more normatively satisfying framework for defining the Fourth Amendment search, one more significant advance for rape victims merits attention. Prior to the enactment of "rape-shield" laws throughout the country, rape victims were often humiliated and embarrassed by the admission of evidence of prior sexual history, in the form of both reputation and prior specific instances, in order to show propensity to consent as well as character for untruthfulness. ${ }^{258}$ Thus, one significant victory for rape victims was the enactment of statutes prohibiting the use of such evidence, subject to a few exceptions. $^{259}$ In addition, many states prohibit introduction of evidence regarding the victim's attire at and before the time of the alleged rape. ${ }^{260}$ In urging the promulgation of rape-shield statutes, reformers sought to encourage victims to come forward without fear of public humiliation and also sought to prevent the "re-

257 See supra note 255.

258 See supra text accompanying notes 173-176.

259 Dressler, Understanding Criminal LAW, supra note 27, at $\S 33.07$; see also Klein, supra note 29, at 990-93. Federal Rule of Evidence 412(b), for example, provides that in criminal trials, evidence of specific instances of the victim's sexual behavior is admissible in three circumstances: to prove that someone other than the defendant was the source of physical evidence (such as semen or injury), to prove consent if the victim's behavior occurred with respect to the defendant, or if constitutionally required. See FED. R. EvID. 412(b).

260 Klein, supra note 29 , at 1028. 
victimization" of those brave enough to come forward and whose complaints resulted in a trial. ${ }^{261}$

As a result of such statutes, the law made significant advances toward shifting the focus away from the victim, in no small part by hampering the defense attorney's ability to persuade a jury that because a victim had freely chosen to engage in intercourse in the past, she likely consented on this occasion as well. This "consent-toone, consent-to-all" argument that is no longer available to defense attorneys in rape trials, however, still very much remains the reasoning of the Court when determining whether police activity constitutes a search. Thus, the adoption of rape-shield provisions provides yet another example of a rape reform that can inform the movement for change in the Fourth Amendment search doctrine, to which this Article turns next.

\section{FRom RAPE LAW TO SEARCH LAW: A QUANTUM LEAP TO A PARALLEL} UNIVERSE

\section{A. Search Law Then (and Now): Helpful to Law Enforcement, Hostile to Victims}

Part III.A has described several features of traditional rape law that imposed significant barriers to conviction. This resulted in a defendant-friendly doctrine that (1) punished only the most egregious conduct; (2) required the prosecution to prove both force and nonconsent, as measured by the victim's most strenuous resistance; (3) exhibited distrust of women complainants; and (4) placed victims on trial, using prior sexual history to show propensity to consent (as well as propensity to lie) and to scrutinize the victim's conduct, essentially allocating to her the blame for her own attack. Similarly, the criminal defendant (or civil plaintiff) seeking to show that she was the victim of an unlawful search faces a comparably difficult challenge; in fact, the first obstacle that must be overcome before a court will turn to any question of legality or reasonableness is simply to demonstrate that a search even occurred.

Drawing on the parallel with traditional rape law, and as will be developed in this part with respect to search law, only the most egregious governmental conduct constitutes a search-the victim must show, through extreme measures to maintain privacy, a clear objection to the intrusion and, further, that the government had to

261 Id. at 991. 
resort to a high level of force to accomplish the surveillance despite that objection. I use the term "force" to mean the measures utilized by the government to overcome efforts to secure privacy. ${ }^{262}$ In addition, the victim's prior acts of disclosure and conduct are scrutinized to show consent (or, in the language of Fourth Amendment search doctrine, the lack of a reasonable expectation of privacy) and to make the victim shoulder the blame for the government's successful surveillance.

To begin, the Court, while purporting to express the expectations of society in defining the Fourth Amendment search, has in reality exempted law enforcement from those very expectations and norms. ${ }^{263}$ In other words, while making "privacy protection appear to hinge on lay people's understandings of how they should treat each other," in its decisions, "the Court has reasoned in terms of a narrow, occupationally-grounded conception of privacy." ${ }^{264}$ As we saw in the rape context, the disparity between how people generally are expected to behave and how the government is permitted (at least for purposes of the Fourth Amendment) to behave has led to police benefitting from what amounts to a "special dispensation from everyday privacy norms, one that doesn't extend to egregious violations but that does encompass minor ones." ${ }^{265}$

While I have already described some of the most intrusive surveillance activities that have indeed achieved the Court's recognition as searches ${ }^{266}$ the best way to illustrate the above point is by showing the kinds of behaviors that are tolerated, perhaps even encouraged, in the name of effective policing, and that are not considered searches, even though the same behaviors committed by the private citizen would be in many cases unlawful or, at the least, highly objectionable. For example, under Fourth Amendment case law, police are permitted to trespass on private property, snoop

262 I do not mean to equate such conduct such as, for example, placing a listening device on the outside of a phone booth, see Katz v. United States, 389 U.S. 347 (1967), or rummaging through garbage, see California v. Greenwood, 486 U.S. 35 (1988), or trespassing, see Oliver v. United States, 466 U.S. 170 (1984), with force as it is understood in the context of rape. I use the term in the search context as a metaphor, and for purposes of illustrating the analogy between these two areas of law.

263 Heffernan, supra note 84, at 5 .

264 Id. at 5-6.

265 Id.

266 See supra Part II.A. 
through garbage, peep through windows, and stalk their prey in public. In Oliver $v$. United States, the Supreme Court reaffirmed its "open fields" doctrine, reasoning that the generally non-intimate activities occurring in open fields do not merit protection from arbitrary government intrusion, and, further, that such lands are still accessible to members of the public or the police, regardless of the existence of fences and/or "No Trespassing" signs, thus making any expectation of privacy in open fields simply not reasonable..$^{267}$ Consequently, the police officers who trespassed upon the defendant's farm to investigate reports of a marijuana crop, reports that were confirmed by their discovery of a field over one mile from the defendant's house, ${ }^{268}$ were simply not governed by the Fourth Amendment at all. Justice Marshall, however, found the majority's decision "startling," 69 and, like him, one may well wonder how Mr. Oliver's expectation of privacy in his land was unreasonable when anybody, other than a police officer that is, choosing to ignore his wishes and enter on his land did so at risk of incurring "the most severe of penalties-criminal liability." ${ }^{270}$

${ }^{267}$ Oliver, 466 U.S. at 179 ("In contrast, open fields do not provide the setting for those intimate activities that the Amendment is intended to shelter from government interference or surveillance. There is no societal interest in protecting the privacy of those activities, such as the cultivation of crops, that occur in open fields."). The Court first announced the "open fields" doctrine in Hester v. United States, 265 U.S. 557 (1924). While still endorsing the textual basis of Hester's reasoning, that an open field does not attain the Fourth Amendment's protection as an "effect," the Court also held the "open fields" doctrine to be consistent with the privacy-based approach of Katz. See Oliver, 466 U.S. at 176-77. The Court's recent decision in United States $v$. Jones did not call into question the holding of Oliver, or the "open fields" doctrine. See United States v. Jones, 132 S. Ct. 945, 953 (2012) ("Quite simply, an open field, unlike the curtilage of a home ... is not one of those protected areas enumerated in the Fourth Amendment.... The Government's physical intrusion on such an area-unlike its intrusion on the 'effect' at issue here-is of no Fourth Amendment significance.”).

268 Oliver, 466 U.S. at 171

269 Id. at 185 (Marshall, J., dissenting).

$270 I d$. at 191 . The field at issue was "highly secluded . . . bounded on all sides by woods, fences, and embankments," not visible from any public area, and marked with regularly posted "No Trespassing" signs. Id. at 174. Officers had to step around a locked gate (with a posted "No Trespassing" sign), pass a barn and camper, from which someone shouted at them to "come back up here," and traverse through woods to arrive at the marijuana field that was the object of their search, and which was surrounded by a chicken-wire fence. Id. at 173-74. Justice Marshall also questioned the majority's conclusion that no activities worthy of privacy occur in fields, noting that " $[\mathrm{m}]$ any landowners like to take solitary walks.... [s]ome landowners use their secluded spaces to meet lovers, others to gather together with fellow worshippers, still others to engage in sustained creative endeavor." $I d$. at 192 (Marshall, J., dissenting). For Justice Marshall, these potential uses of private 
So, while in Oliver, criminally liable interlopers set the benchmark of conduct, the Court did not raise the bar much in California v. Greenwood, as the police, who sifted through defendant's curbside trash, were held to no higher standard than scavengers and snoops, even raccoons. ${ }^{271}$ Needless to say, if an individual followed another's every movement out in public, ${ }^{272}$ or hovered about peering into another's back yard, ${ }^{273}$ that individual would be considered a stalker. Yet, the police are permitted to conduct just this type of concentrated surveillance, and with the aid of technology no less. The reason that such police violations of social and, often, legal norms give the Court such little cause for concern is that, under Fourth Amendment search doctrine, the emphasis falls squarely on the victim and her expectations, and it seems that the individual asserting a Fourth Amendment interest cannot reasonably expect more from the police than can be expected from any member of the public, even a criminal. ${ }^{274}$ It is not surprising that such an approach results in government surveillance being so frequently held to not even trigger the Fourth Amendment. ${ }^{275}$

property merit protection, and the fact that the property was, in fact, being used for cultivation of marijuana is irrelevant to the constitutional analysis. Id. at 191 .

271 California v. Greenwood, 486 U.S. 35, 40-41 (1988) (holding that there is no reasonable expectation of privacy in garbage left at the curb for collection, as "[i]t is common knowledge that plastic garbage bags left on or at the side of a public street are readily accessible to animals, children, scavengers, snoops, and other members of the public."); see Heffernan, supra note 84, at 38; Colb, supra note 84, at 128 ("When the garbage was at the curb, Greenwood's hypothetical snoopy neighbor might have had to violate the law to rummage through it in the way that the police officer did.").

272 See United States v. Knotts, 460 U.S. 276 (1983) (holding that the attachment of an electronic radio transmitter (or "beeper") to a container of chloroform purchased by defendant, and monitoring the movement of that container in public, constituted neither a seizure nor a search, as defendant had no reasonable expectation of privacy with respect to his public movement, which could have been monitored by naked-eye observation as well). The Court's decision in United States $v$. Jones also did not affect the holding in Knotts, as in the former case, the GPS device was affixed to the car after it was under the control of the defendant, thus constituting a physical trespass upon an effect, while in the latter case, the defendant received the container with the beeper already attached. See United States v. Jones, 132 S. Ct. 945, 951 (2012).

${ }^{273}$ See California v. Ciraolo, 476 U.S. 207 (1986) (holding that aerial surveillance of defendant's curtilage from an airplane at an altitude of 1,000 feet did not constitute a search); Florida v. Riley, 488 U.S. 445 (1989) (holding that aerial surveillance of defendant's greenhouse from a helicopter hovering at an altitude of 400 feet did not constitute a search).

274 See Colb, supra note 84, at 137 ("People who rummage through their neighbors' garbage, trespass on fenced-off fields, and stalk people . . . are criminals who intrude on upon others' sense of security, safety, and privacy.”).

275 See 1 Dressler \& Michaels, Understanding Criminal Procedure $§ 6.04$ (5th 
As with traditional rape law, the definition of a search also requires both the use of force by the perpetrator (here, the government) and the victim's nonconsent, with resistance as the catalyst. As in the rape context, it is difficult to separate force from nonconsent; if the subject of surveillance makes any effort to conceal information, then some level of force, be it walking around a locked gate, sifting through garbage, paying an informant, or hiring a pilot to fly a small plane, is required in order to obtain that information. In fact, Professor Wayne LaFave provides the following example of a traditional definition of a search as implying:

some exploratory investigation, or an invasion and quest, a looking for or seeking out. The quest may be secret, intrusive, or accomplished by force, and it has been held that a search implies some sort of force, either actual or constructive, much or little. A search implies a prying into hidden places for that which is concealed and that the object searched for has been hidden or intentionally put out of the way. ${ }^{276}$

Regrettably, the Court has given little attention to the use of such force by police, and where it has, it has defined it narrowly and unrealistically, without addressing or answering, in any satisfying way, the most important question in defining a Fourth Amendment search: should the police be permitted to engage in certain surveillance practices with no constitutional oversight, or is the threat to personal freedom and security from such unregulated power simply too great a burden on a free society? ${ }^{277}$

Professor Dressler identifies the following three factors that the Court has turned to in defining searches: (1) the location being observed; (2) the measures taken to maintain privacy; and (3) the degree of intrusion, which can be understood as encompassing the severity of physical intrusion as well as the quantity and quality of the information being observed. ${ }^{278}$ In this framework, one can readily see

ed. 2010). Professors Dressler and Michaels suggest that a counter-trend may well be underway. See id. This Article addresses some of the cases that lend support for the conclusion that the Court has indicated a willingness to reconsider, to some extent, its current approach to defining the search in Part IV.

276 Wayne R. LaFave, SEARCh AND SEIZure: A Treatise ON the Fourth AMENDMENT $\$ 2.1$ (4th ed. 2011) (quoting C.J.S., Searches and Seizures 11 (1952)).

277 Amsterdam, supra note 41, at 403; see also United States v. White, 401 U.S. 745, 768-69 (1971) (Harlan, J., dissenting).

278 DRESSLER \& MiCHAELS, supra note 275, at 79; see also Wilkins, supra note 109, at 1081 (arguing that the Court should explicitly adopt the framework that it implicitly has utilized in defining searches, namely, examining the "place where governmental 
force (the degree of intrusion) and nonconsent (demonstrated by measures to exclude). Focusing first on force, how does the Court assess the methods used by police to discover information? If the Court even acknowledges the illegality of police conduct, the fact that the police are breaking the law while conducting surveillance is given little weight in determining whether a search occurred. One need not look further than Oliver for an example of the Court's approach to police lawlessness. In Oliver, the officers undoubtedly were trespassing on private land, something noted by the Court. ${ }^{279}$ But as quickly as the Court recognized the trespass, it stripped it of any real significance: "The premise that property interests control the right of the Government to search and seize has been discredited.' ... For trespass law extends to instances where the exercise of the right to exclude vindicates no legitimate privacy interest." 280

On the other hand, if the police are acting within the bounds of the law, or not violating any rules or regulations, the legality of their conduct becomes a central factor in defining the conduct as a nonsearch. Thus, in the "flyover" ${ }^{281}$ cases, the Court emphasized the fact

surveillance occurs, the intrusiveness of the procedures used, and the object of the surveillance itself."). For purposes of this Article, the focus when discussing intrusiveness is on the methods used by police to conduct surveillance, rather than on the object of that surveillance. Although the Court has discussed the nature of what is actually observed or discovered by the police as a factor in determining whether or not government conduct constitutes a search, this should be irrelevant in determining whether or not the government conduct constitutes a search. See Florida v. Riley, 488 U.S. 445, 446 (1989) (noting, as a factor supporting the conclusion that no search occurred when police observed the contents of the defendant's greenhouse from a helicopter, that no "intimate details about connected with the use of the home or curtilage ... were observed"). For example, if police peer into a backyard, it should not matter, constitutionally speaking, whether they observe marijuana plants or a naked sunbather; what matters is that they observed the contents of an area that could contain either, and they are in no position to know what the yard may contain until after they have observed it. See DrESSLER \& MiCHAELS, supra note $275, \S 6.07$ ("Can the Court possibly mean that if the same helicopter had observed the contents of the greenhouse as well as consensual but illegal sexual acts in the backyard, the surveillance would have been a "search" of one but not of the other activity?").

279 Oliver v. United States, 466 U.S. 170, 182-83 (1984).

280 Id. (quoting Katz v. United States, 389 U.S. 347, 353 (1967)). Again, is ironic that the Court quotes the language of Katz, meant to expand the reach of the Fourth Amendment beyond the protection delineated by traditional property rights, to narrow the reach of the Amendment by making property rights irrelevant when they are in fact implicated.

281 In referring to the "flyover" cases for purposes of this Article, the discussion is limited to Ciraolo and Riley, which involved the aerial observation of residential curtilage. The Court also upheld such observation, aided by a professional camera, of commercial curtilage in Dow Chemical Co. v. United States, 476 U.S. 227 (1986). 
that police were flying, or hovering, at altitudes permitted by safety regulations. ${ }^{282}$

It is interesting to note the inconsistency between Oliver, on the one hand, and Ciraolo and Riley, on the other. In Oliver, police were trespassing, but that fact was irrelevant because the observation occurred in a location, according to the Court, that did not merit protection. In other words, the field that police entered upon was not considered part of the curtilage of the home, an area in which one generally harbors an expectation of privacy because of its intimate connection to the home:

At common law, the curtilage is the area to which extends the intimate activity associated with the "sanctity of a man's home and the privacies of life," and therefore has been considered part of home itself for Fourth Amendment purposes. Thus, courts have extended Fourth Amendment protection to the curtilage; and they have defined the curtilage, as did the common law, by reference to the factors that determine whether an individual reasonably may expect that an area immediately adjacent to the home will remain private. ${ }^{283}$

In Ciraolo and Riley, police observed the contents of the defendants' backyard and greenhouse, respectively, each within the curtilage of the defendants' homes. ${ }^{284}$ One might think, after Oliver, that the legality of police conduct would have been of secondary importance to the nature of the location being observed, but it seems

282 See California v. Ciraolo, 476 U.S. 207, 213 (1986) ("The observations ... took place within public navigable airspace.”); see also Riley, 448 U.S. at 451. The plurality in Riley notes the fact that the police are not breaking the law repeatedly: "We would have a different case if flying at that altitude had been contrary to law or regulation .... This is not to say that an inspection of the curtilage of a house from an aircraft will always pass muster under the Fourth Amendment simply because the plane is within the navigable airspace specified by law. But it is of obvious importance that the helicopter in this case was not violating the law ...." Id. Justice O'Connor, writing separately, concurred with the plurality, although for her, the relevant question was not whether the flight complied with safety regulations, but whether such flight was sufficiently "regular." Id. at 454 (O'Connor, J., concurring). She concluded that there was enough evidence of such regularity, although she placed the burden on the defendant to show otherwise. Id. at 455.

283 Oliver, 466 U.S. at 180. In United States v. Dunn, 480 U.S. 294, 301 (1987) the Court provided a number of factors to aid in the determination of whether an area is considered curtilage: (1) the proximity of the area claimed to be curtilage to the home; (2) whether the area is included within an enclosure surrounding the home; (3) the nature of the uses to which the area is put; and (4) the steps taken by the resident to protect the area from observation by people passing by.

284 Ciraolo, 476 U.S. at 212-13; Riley, 448 U.S. at 450. 
that the Court, in each of these surveillance contexts, chose to focus on the specific factor, either police conduct or location, that supported the ultimate finding that no search had occurred.

Moreover, in the flyover cases, not only did the Court focus on the legality of the flights, but also made mention, in Ciraolo, that the surveillance was conducted in a "physically nonintrusive manner," and, in Riley, that there was no evidence

that the helicopter interfered with respondent's normal use of the greenhouse or of other parts of the curtilage. As far as this record reveals, ... there was no undue noise, and no wind, dust, or threat of injury. In these circumstances, there was no violation of the Fourth Amendment. ${ }^{286}$

In both these cases, then, the Court embraced the same property-based, trespass analysis that Katz repudiated, at least to the extent that it supported the outcome in favor of law enforcement. ${ }^{287}$ Perhaps this is an attempt by the Court to at least nominally address the conduct of the police (what this Article refers to as force) in some way, although the discussion is superficial, void of normative content, and also, perhaps, disingenuous. The Court clings to property law when it is helpful to the government, and disavows property norms when those norms would be helpful to individuals seeking to claim the protection of the Fourth Amendment.

Again, traditional rape law can provide an explanation for the Court's somewhat empty examination of police conduct. As noted by Professor Estrich, the resistance requirement in rape law relieved courts of the difficult task of defining force in the context of rape. ${ }^{288}$ Similarly, in the search context, the Court's focus on the victim's expectations - as measured in significant part by resistance, or efforts to maintain privacy — spare the Court from having to look too closely at the government's conduct. Resistance also has a role in demonstrating the victim's nonconsent to surveillance, to which this analysis will turn shortly, but first, it is helpful to further explore resistance in its relationship to force. While this Article does not propose eliminating the resistance requirement entirely from the definition of a search, it does submit that currently, in order for

285 Ciraolo, 476 U.S. at 213

286 Riley, 448 U.S. at 452.

287 Professor Orin Kerr notes that the "Court's opinions have sent conflicting rhetorical signals" with respect to the place of property law after Katz. See Orin S. Kerr, The Fourth Amendment and New Technologies: Constitutional Myths and the Case for Caution, 102 Mich. L. REv. 801, 825 (2004).

288 See Estrich, supra note 28 , at 1130 . 
government surveillance to qualify as a search, it must overcome what amounts to utmost resistance, such as was required in traditional rape law, placing too great a burden on the victim.

The Article's analysis returns once more to the flyover cases, specifically Ciraolo, to provide the clearest illustration of the utmost resistance requirement at work. Turning first to Mr. Ciraolo's efforts to keep the contents of his backyard to himself, the Court offers the following description of the non-search that revealed the marijuana plants in that yard:

Police were unable to observe the contents of respondent's yard from ground level because of a 6 -foot outer fence and a 10-foot inner fence completely enclosing the yard. Later that day, Officer Shutz, who was assigned to investigate, secured a private plane and flew over respondent's house at an altitude of 1,000 feet, within navigable airspace; he was accompanied by Officer Rodriguez. Both officers were trained in marijuana identification. From the overflight, the officers readily identified marijuana plants 8 feet to 10 feet in height growing in a 15- by 25-foot plot in respondent's yard; they photographed the area with a standard 35mm camera.

What kind of resistance, then, did Mr. Ciraolo offer against the visual invasion of his home? The Court grudgingly acknowledged that he "took normal precautions to maintain his privacy,"290 although the fact that Mr. Ciraolo erected not one, but two tall fences completely enclosing his yard indicates, at least to my mind, something more than "normal precautions." So, while the Court conceded that he had a reasonable expectation of privacy from ground-level observation, it was not so generous in acknowledging any such expectation from aerial surveillance.

What would the Court have required from Mr. Ciraolo? It seems, nothing less than the utmost resistance would have sufficed to endow Mr. Ciraolo with a reasonable expectation of privacy in the contents of his yard, which included, although completely overlooked by the majority, a swimming pool and sunbathing patio. ${ }^{291}$ In other

289 Ciraolo, 476 U.S. at 209.

$290 I d$. at 211 (quoting Rawlings v. Kentucky, 448 U.S. 98, 105 (1980)).

291 See Ciraolo, 476 U.S. at 222 n.7 (Powell, J., dissenting). The majority chose to describe the defendant's desire for privacy in the specific terms of his efforts to conceal his marijuana plants, rather than in more general terms of an intent to keep his backyard private, as an area for personal outdoor enjoyment, used as much for swimming and sunbathing as for "unlawful agricultural pursuits." See id. at 211. 
words, by not placing a roof over his yard, something, as Justice Powell noted, few people do, ${ }^{292} \mathrm{Mr}$. Ciraolo knowingly exposed the contents of his yard to passengers of low-flying aircraft, or even to hypothetical police officers surfing atop trucks and double-decker buses. $^{293}$ Engaging, again, the parallel to traditional rape law, the victim bears the burden of preventing the intrusion in the first place, ${ }^{294}$ which Mr. Ciraolo was unable to accomplish with his two tall fences.

If effectiveness of resistance is used to define the level of force necessary before something can be qualified as a search, then clearly, by the Court's measure, the force used by the officers in Ciraolo was not at such a level as would trigger the Fourth Amendment. The Court described the officers' conduct as "simple visual observations from a public place," ${ }^{295}$ reasoning that the Fourth Amendment does not require "officers to shield their eyes when passing by a home on public thoroughfares." ${ }^{296}$ Thus, according to the majority, the officers observed nothing more than any member of the public "who glanced down" would have seen if flying at that altitude. ${ }^{297}$

Let us take a slightly more realistic approach to describing the force needed to overcome Mr. Ciraolo's resistance. First, officers went to Mr. Ciraolo's home and attempted to view the contents of the yard from ground level, but were prevented from doing so by the two fences. Determined nevertheless to accomplish the surveillance of the yard, the lead officer hired a pilot to fly a private plane over the yard, so that he and another officer, trained in the identification of marijuana, could ascertain whether or not the yard did indeed contain the suspected marijuana, a fact the officers could not know with certainty until after they completed the inspection of the yard. As much as Mr. Ciraolo took "normal precautions" to shield his property from visual intrusion, the officers engaged in extraordinary measures to circumvent those precautions. One is again reminded of traditional rape law, as it reflected an understanding of the sexual roles of men and women under which men were expected to increase their persistence in the face of a woman's protests and, indeed, under which such protests, if falling short of the most vigorous physical

${ }^{292}$ Id. at 224 (Powell, J., dissenting).

293 Id. at 211.

294 See supra text accompanying note 180.

295 Ciraolo, 476 U.S. at 214

$296 \quad I d$. at 213.

297 Id. at $213-14$ 
obstacle to the man, were deemed an invitation for men to pursue more aggressively. ${ }^{298}$

To equate what Justice Powell, in his dissent, described as "an overflight at low altitude solely for the purpose of discovering evidence of crime within a private enclave into which they were constitutionally forbidden to intrude at ground level without a warrant" ${ }^{299}$ with the casual glance of the business or recreational air traveler into an unidentified yard during takeoff or landing is simply unrealistic and, as Justice Powell concluded, does not accurately measure the risk to privacy associated with such directed police surveillance. In fact, Justice Powell noted that the everyday risk to privacy from aerial observation by the general public is so minimal that few people feel the need to build roofs over their yards to shelter their outdoor living activities (as opposed to erecting fences to surround their properties). ${ }^{300}$ Of course, another reason that few people build roofs over their yards is the fact that this particular precaution is unfeasible and would essentially destroy the very space it is meant to protect-that little piece of home in which family and friends can gather to enjoy air, sun, sky, and yes, maybe a little garden as well. Ciraolo clearly exemplifies a definition of a search that rewards police for resorting to extreme efforts to overcome some unfeasible level of resistance. Again, the parallel to traditional rape law is striking. ${ }^{301}$

If we now turn to resistance in its second role, as evidence of nonconsent, then surely Mr. Ciraolo demonstrated that he had no intention of permitting members of the public, no less the police, access (visual or physical) to his yard. Yet, he barely survived the Court's application of the first prong of Justice Harlan's Katz test: whether he "manifested a subjective expectation of privacy in the object of the challenged search ...."302 The Court began by stating

298 See supra notes 191-194 and accompanying text.

299 Ciraolo, 476 U.S. at 224-25 (Powell, J., dissenting).

$300 \quad$ Id. at 224 (Powell, J., dissenting)

301 See supra note 194 and accompanying text.

302 Ciraolo, 476 U.S. at 211 (emphasis added). The Ciraolo majority actually modified Justice Harlan's language slightly by adding the highlighted phrase "in the object of the challenged search." See id. This is not the only time we have seen this prong altered, and the reader may recall that the Court, in Rakas v. Illinois, 439 U.S. 128, 148 (1978), also referred to a "legitimate expectation of privacy in the particular areas searched." (emphasis added). Although Justice Harlan, in Katz, stated that the inquiry "[g]enerally . . requires reference to a "place,", it does not necessarily need to. Katz v. United States, 389 U.S. 347, 361 (1967) (Harlan, J., concurring). The proper test for this first prong, to use Justice Harlan's exact language, is, simply, 
that "[c]learly_and understandably-respondent has met the test of manifesting his own subjective intent... to maintain privacy ...." ${ }^{303}$ Despite the fact that this finding was not challenged below, and that the Court acknowledged it was not necessary to address this issue, the Court nonetheless felt compelled to do precisely that. What was once clear became "not entirely clear," as the Court, hypothesizing about the inadequacy of the 10-foot fence to protect against citizens and police peering into the yard from the roof of a tall vehicle, suggested that Mr. Ciraolo had merely a "hope" that his "unlawful gardening pursuits" would be free from observation, rather than an "expectation of privacy from all observations of his back yard." ${ }^{304}$

What the Court seemed to be saying here is that in order to even demonstrate a subjective expectation of privacy, one must have taken precautions against any possible invasion, again exhibiting an unrealistic and overly permissive view of force and an equally unrealistic and overly oppressive requirement of resistance. How can one ever have an expectation that the precautions taken will be

whether the individual has "exhibited an expectation of privacy." Id. Adding a limiting phrase, referring to places or objects, allows the Court to manipulate the concept of privacy by mooring it to something specific, rather than allowing for a more expansive (albeit more nebulous) understanding of privacy. In Ciraolo, then, what exactly is the "object" of the search? The Court begins by examining whether the defendant manifested a desire to keep "his unlawful agricultural pursuits" private. Ciraolo, 476 U.S. at 211. Once the expectation of privacy is associated specifically with the object that is discovered (or the object of the search), it is a small step to find no legitimate expectation in that particular object. In Ciraolo, the majority focuses on the fact that the marijuana plants were observed in the yard, and does not mention other features of the yard that were also viewed and the human activity that, at any given time, could have been viewed. See supra note 291 and accompanying text. In the binary search context, meaning that the search can only reveal the presence or absence of contraband and nothing else, the Court has reasoned that individuals have no legitimate expectation of privacy in the possession of contraband, and that the absence of contraband is not information that reasonably matters to anyone, thereby permitting field drug testing and dog sniffs of luggage and cars. See Illinois v. Caballes, 543 U.S. 405 (2005) (holding that the dog sniff of a vehicle does not constitute a search); United States v. Jacobson, 466 U.S. 109 (1984) (holding that the dog sniff of luggage is not considered a search); United States v. Place, 462 U.S. 696 (1983) (holding that the field testing of a small quantity of powder to ascertain whether it was cocaine was not considered a search). Thus, because the Court has determined that there is no legitimate expectation of privacy in either possessing or not possessing contraband, these activities are not considered searches, but note that by defining the expectation of privacy narrowly in terms of the contraband, the Court did not recognize a broader notion of privacy, one that would entitle people to retain control over information of the contents, whether contraband or not, of their personal belongings.

${ }^{303}$ Ciraolo, 476 U.S. at 211.

${ }^{304}$ Id. at 211-12 (emphasis in original). 
absolutely impervious to penetration? Under the Ciraolo Court's reasoning, then, it seems that even Mr. Katz would have had difficulty fulfilling this part of the test, as, failing to check the phone booth he used for external bugs, he did not take sufficient precautions and his conversation was, after all, intercepted. What the Ciraolo Court failed to take into account was that Mr. Katz didn't sweep the public phone booth for bugs because it was reasonable for him to expect there would be none, just as it was unreasonable for the agents investigating him to place atop the booth the device that ultimately revealed the contents of Mr. Katz's conversation. ${ }^{305}$ The Ciraolo Court, in contemplating trucks, double-decker buses, and, ultimately, lowflying aircrafts, as vehicles for spying into Mr. Ciraolo's back yard, never took into account the fact that the ordinary citizen would not expect (and therefore would not protect against) such behavior. ${ }^{306}$

Professor Sherry Colb has identified two flaws in the Court's reasoning with respect to defining searches, both of which this Article will discuss in the context of the victim's consent. ${ }^{307}$ The first of these is exemplified by the Court's reasoning in Ciraolo. According to Professor Colb, the Court has equated the risk of exposure with what this Article refers to as consent, or, in Katz parlance, "knowing exposure." ${ }^{308}$ Recall that in Katz, the Court reasoned that, even in the most protected of spaces-the home, what one "knowingly exposes to the public" is not protected by the Fourth Amendment. ${ }^{309}$ This idea of knowing exposure implies that an individual has in some way, either actually or constructively, consented to the observation. Although the Court has chosen to refer to consent searches as those searches in which an individual affirmatively grants permission to search specifically to the police, ${ }^{310}$ as opposed to merely exposing information to members of the public, which is not considered to be

305 This Article refers to the reasonableness of the measures used to intercept Mr. Katz's conversation, judged by commonly understood social norms (for purposes of defining the search), rather than to reasonableness of the agents' surveillance in the more specialized sense of the Fourth Amendment's prohibition of unreasonable searches and seizures (for purposes of ascertaining whether or not a search or seizure, once recognized as such, comports with that Amendment's requirements).

306 The dissent, of course, makes this precise argument. Ciraolo, 476 U.S. at 223-24 (Powell, J., dissenting).

See Colb, supra note 84, at 122

308 Id.

309 Katz v. United States, 389 U.S. 347, 351 (1967).

310 A search pursuant to valid consent is considered to be a reasonable search and is exempted from the usual (at least, in theory) requirements of probable cause and a warrant. See Schneckloth v. Bustamonte, 412 U.S. 218, 227 (1973). 
a search at all, for purposes of analogy, this Article will refer to the victim's consent or nonconsent as relevant to determining what type of police conduct constitutes a search. ${ }^{311}$

Despite the Court's equivocality on the matter, this author remains convinced that Mr. Ciraolo did not consent to the viewing of his yard and adequately conveyed his nonconsent to the world. One is reminded of the paradox identified by Professor Estrich in her repudiation of Alston-that the sexual intercourse at issue was at once against the will of the victim, yet somehow not committed by force, and therefore the perpetrator was not guilty of rape. ${ }^{312}$ The paradox may be even more puzzling in the search context. Mr. Ciraolo did not consent, and he communicated his nonconsent. Yet, his "no" was not respected, not by the police, not by the Court, and not even, at least as the Court determined, by society. As already discussed, his resistance was not deemed adequate because it could not prevent the method of surveillance the police ultimately resorted to in order to view his yard. ${ }^{313}$ By the same token, because he failed to prevent all efforts at securing the privacy of his yard, his nonconsent was also discounted, and the Court treated the vulnerability to visual penetration from the airways as "knowing exposure." "314 So, just as

311 As Professor Colb points out, Justice Marshall expressed a similar understanding of the central role of consent in defining a search, in that according to his (dissenting) view, a citizen's consent to a search constitutes a choice not to exercise one's Fourth Amendment right to exclude the government, a choice that can only have meaning with the knowledge of the right to refuse that consent. Colb, supra note 84, at 123. See Schneckloth v. Bustamonte, 412 U.S. 218, 283 (1973) (Marshall, J., dissenting). This understanding of consent-that a consent search is in fact not really a search at all-is inherently logical. For example, how would it be possible for one to invite the police to enter her home, and yet retain a reasonable expectation of privacy in the contents of the home? In fact, the Court used the very assumption-of-risk rationale often used to find no reasonable expectation of privacy to validate third-party-consent searches, holding that any joint occupant of premises may consent to a search of areas of common authority, the fruits of which are admissible against a co-occupant. See United States v. Matlock, 415 U.S. 164, 171 (1974) (" $[\mathrm{I}] \mathrm{t}$ is reasonable to recognize that any of the co-inhabitants has the right to permit the inspection in his own right and that the others have assumed the risk that one of their number might permit the common area to be searched."). Professor Colb argues that these two strands of search doctrine should be reconciled and that equating consent with knowing exposure might lead the Court to define knowing exposure as truly knowing (rather than accidental or unintended), and to require that consent, to be valid, also be knowing. Colb, supra note 84, at 123.

312 See supra notes 155-156 and accompanying text.

313 In other words, just as Professor Anderson described rape victims' burden to live up to a high standard of resistance, see Anderson, supra note 29, at 957-58, Mr. Ciraolo likewise failed to measure up to some ideal level of resistance.

314 California v. Ciraolo, 476 U.S. 207, 215 (1986). 
Cottie Brown said "no," yet somehow the physical penetration of her body was accomplished without force, Mr. Ciraolo also said "no," but was nonetheless deemed to have consented, making the visual penetration of his yard non-forceful as well.

Ciraolo is but one of many cases in which the Court has relied on this rationale, holding government surveillance not to constitute a search because the individual has assumed the very risk of exposure that the government exploits. Worse still, the risk contemplated by the Court often involves some act of wrongdoing by a third party, in the form of a violation of either the law or, at the least, a social norm. ${ }^{315}$ As this Article has already described, under the Fourth Amendment, the government is permitted to trespass, rummage through garbage, and stalk its citizens to gain access to information it otherwise would not be able to acquire-information the government seeks to use in wielding its power against those it has targeted. ${ }^{316}$ Somewhat ironically, when the Court evaluates the government's force, the criminal or anti-social behavior actually committed by police is given little, if any, weight, but the mere possibility of such behavior on the part of members of the public, on the other hand, no matter how speculative, is heavily relied on to discredit individuals' assertions of nonconsent. In other words, the Court recognizes the prevalence of illegal or socially undesirable conduct inconsistently-acknowledging lawlessness in people at large but downplaying similar lawlessness on the part of law enforcementweakening both elements (as these elements are conceived for purposes of analogy) of a search: the victim's nonconsent and the force used to overcome that nonconsent.

So, similarly to traditional rape law, the force needed to qualify

315 Colb, supra note 84, at 122. Professor Colb demonstrates the perverse outcome of equating risk-taking with knowing exposure, in that wrongdoing on the part of the police is not only excused, but seemingly justified, by invoking the image of a man who imprudently falls asleep on a subway, thereby opening himself up to the very real risk of being pick-pocketed. See id. As easy as it may be for a criminal to reach into the sleeping man's pocket and remove his wallet, stealing the wallet remains a crime, and the victim did not, in fact, invite anyone to take his wallet, no matter that he should have remained more vigilant and even though some might say that he "asked to have his pocket picked." Id.

316 See supra notes 267-273 and accompanying text. Professor Colb thoroughly explores the Court's use of this reasoning in a variety of surveillance contexts in which it has been held that individuals lack a reasonable expectation of privacy, discussing the Court's search jurisprudence involving garbage, open fields, flyovers, tracking devices, hidden video cameras, and false friends. See Colb, supra note 84, at 127-44. For purposes of this Article, I have highlighted only a few examples from the Court's search cases to illustrate my comparison to traditional rape law concepts. 
to meet the definition of a search is given a narrow construction, as is nonconsent. And, if nonconsent is construed narrowly, consent is simultaneously given overly generous breadth, leading us to the second flaw identified by Professor Colb. The Supreme Court has also equated knowing, but selective, exposure with knowing exposure, period. ${ }^{317}$ In other words, the Court has treated voluntarily sharing information with a limited number or for a limited purpose as identical to voluntarily disclosing that same information to the whole world, thus "failing to recognize degrees of privacy." "318 So, when we seek to place a call from our home telephone, the number we have dialed is not protected because we have provided it, not even to another human being, but to a machine. ${ }^{319}$ In doing so, we have "assumed the risk that the [phone] company would reveal to police" the dialed numbers, and therefore, we cannot harbor a reasonable or "legitimate" expectation of privacy in those numbers. ${ }^{320}$ Likewise, when we deposit money to our bank, we have relinquished any claim to Fourth Amendment protection for our financial information, because " $[\mathrm{t}]$ he depositor takes the risk, in revealing his affairs to another, that the information will be conveyed by that person to the Government." ${ }^{321}$ In both of these situations, we have revealed information to a specific entity for a limited and specific purpose. Further, both these risks are, of course, exceedingly difficult, if not impossible, to avoid while going about our lives in today's highly interdependent society. ${ }^{322}$

317 Colb, supra note 84, at 122

318 Id. Justice Sotomayor, concurring in United States $v$. Jones, recognized the gravity of this flaw:

More fundamentally, it may be necessary to reconsider the premise that an individual has no reasonable expectation of privacy in information voluntarily disclosed to third parties. This approach is ill suited to the digital age, in which people reveal a great deal of information about themselves to third parties in the course of carrying out mundane tasks... whatever the societal expectations, they can attain constitutionally protected status only if our Fourth Amendment jurisprudence ceases to treat secrecy as a prerequisite for privacy. I would not assume that all information voluntarily disclosed to some member of the public for a limited purpose is, for that reason alone, disentitled to Fourth Amendment protection.

United States v. Jones, 132 S. Ct. 945, 957 (Sotomayor, J., concurring).

319 Smith v. Maryland, 442 U.S. 735 (1979). The Court analogized the switching equipment used to complete the call to the human telephone operator of the past. Id. at $744-45$.

Id. at 744

321 United States v. Miller, 425 U.S. 435, 443 (1976).

322 In addition to phone numbers and bank records, Professor Colb also critically 
Still more troubling, perhaps, is the government's use of "false friends," a category of surveillance involving undercover agents and informants that is also unregulated by the Fourth Amendment. Just as with the phone numbers we dial and the financial information we disclose to a bank, the Court has held that when we confide in another, whether that other is an old friend who betrays us, or a new friend whose very existence in our lives has been artificially created in order to gain information for use against us, we have no reasonable expectation of privacy in what we have revealed. ${ }^{323}$ This type of surveillance, aptly characterized by Professor William Heffernan as "interactive surveillance," involves something potentially more harmful, on a deeply personal level, than the police wrongdoing we have thus far encountered:

$[\mathrm{W}]$ ith interactive surveillance, government agents try to penetrate human relationships to discover information or objects of evidentiary value. The penetration can be carried out by deception.... But the penetration can also be carried out by acts of betrayal.... In forging ties with others, people take the risk, the Court maintains, that the government has either planted friends among them or, the associations having been formed, that it has induced their friends to turn on them. ${ }^{324}$

Yet, the government is permitted to manipulate and interfere in our personal relationships with no justification or oversight for the same reason as it may access our bank records: because we have consented to the sharing of information with some small part of our world (whether business or personal), we are deemed to have consented towards everyone, including the government. If this sounds familiar to the reader, it should. Recall the use, in a rape trial, of the victim's prior sexual history to make a strikingly similar

examines the Court's use of this rationale with respect to garbage. Colb, supra note 84, at 153-55. An alternate justification of the holding of California v. Greenwood, 486 U.S. 35 (1988), rested on the idea that by leaving her garbage on the curb for the trash collector, a homeowner not only assumes the risk posed by snoops and scavengers, but also bears the risk that the collector might peruse the contents of the trash or, even worse, invite the police to do so, rather than disposing of it in the usual way. Greenwood, 486 U.S. at 40.

${ }_{323}$ See United States v. White, 401 U.S. 745 (1971); Hoffa v. United States, 385 U.S. 293 (1966); On Lee v. United States, 343 U.S. 747 (1952).

${ }^{324}$ Heffernan, supra note 84, at 106-07. Professor Heffernan argues that while the Fourth Amendment cannot regulate an insider's choice, of her own volition, to betray the subject of the government's interest, the Fourth Amendment should be implicated when the government "takes steps on its own to penetrate intimate relationships." Id. at 109-10. 
argument: because she has consented to one instance of sexual activity (or perhaps more) in the past, she is likely to consent to any and all, and therefore, equally likely to have consented to the specific instance of intercourse she claims to be a rape.

In many ways, then, current search law mirrors traditional rape law. Each doctrine favors the perpetrator of the violation-ironically, the government in the former context and the defendant in the latter-and places a substantial burden on the victim claiming the violation. In each context, force is construed narrowly and consent, broadly. Great demands are placed on the victim to resist, else the violation will not be deemed a search or a rape, as the case may be. And, the victim is said to have assumed the risk of the violation if she is perceived as somehow having caused or contributed to the vulnerability that is exploited against her, by engaging in risky behavior or through her associations with others. With such parallel structural features reflecting and reinforcing an imbalance of power between government and defendant, on the one hand, and male perpetrator and female victim, on the other, it should not be surprising that Fourth Amendment scholars have likewise identified broader social concerns stemming from the Court's jurisprudence, to which the Article now turns.

\section{B. Search Law Under Siege}

Part III.B began by noting the disparity in physical strength, generally speaking, between men and women, which of course makes it more difficult for a female victim to prevent unwanted intercourse in the face of a truly determined perpetrator. At the same time, traditional rape law failed to realistically evaluate this imbalance of strength and power, placing squarely on the victim the responsibility of resorting to extraordinary physical measures to thwart the violation of her person. So, too, the target of government surveillance faces a similar disadvantage when all the power and resources of the State are brought to bear upon her, and similarly, the law of searches also requires extraordinary measures to maintain privacy in the face of the government's determination to breach that privacy and obtain the information it seeks.

The Court's unrealistic assessment of the imbalance of power between law enforcement and the individual, ${ }^{325}$ and the Court's willingness to permit the government to exploit that imbalance, have

325 See supra note 234. 
resulted in a Fourth Amendment that has been noted by scholars to be "a whites-only amendment," "226 to "create and sustain" a racially biased world, ${ }^{327}$ and to include a "poverty exception" to its protections. $^{328}$ In short, the Court's decidedly government-friendly doctrine has disadvantaged citizens not only in their individual capacities viz-a-viz law enforcement, but has also developed in ways that particularly affect individuals as members of larger groups, namely minorities and the poor.

A great deal has been written on the subject of race and the Fourth Amendment, and the scholarship is replete with examples of legal doctrines and police practices that negatively and disproportionately impact minority citizens. ${ }^{329}$ For present purposes, this Article focuses on poverty and its relationship to the definition of a search, in particular the disadvantage to the poor inherent in a definition of a search that places almost exclusive emphasis on precautions taken to preserve privacy and punishes deviation from the proscribed level of diligence. This is not to say that this analysis overlooks the implications of search doctrine on minorities. As noted by many scholars, the "huge economic disparities that persist between the races" play a major role in the continued segregation of minority groups to poor, urban, high-crime areas. ${ }^{330}$ Professor Amy Ronner

326 Ronner, supra note 64, at 423.

327 Devon W. Carbado, (E)racing the Fourth Amendment, 100 MicH. L. REv. 947, 968 (2002). Professor Carbado argues that a colorblind doctrine that takes note of race only when a police officer is engaging in obvious racist behavior "obscures ... the racial allocation of the burdens and benefits of the Fourth Amendment. The material result of this racial allocation is that people of color are burdened more by, and benefit less from, the Fourth Amendment than whites." Id. at 968-69.

${ }_{328}$ Christopher Slobogin, The Poverty Exception to the Fourth Amendment, 55 FLA. L. REv. 391, 404 (2003).

${ }^{329}$ See generally Carbado, supra note 327, at 969; Anthony C. Thompson, Stopping the Usual Suspects: Race and the Fourth Amendment, 74 N.Y.U. L. REV. 956 (1999); Tracey Maclin, Race and the Fourth Amendment, 51 VAND. L. REV. 333 (1998) [hereinafter Maclin, Race and the Fourth Amendment] (discussing the history and present state of race-based policing and the disproportionate impact on African Americans of discretionary, pretextual seizures); Sheri Lynn Johnson, Race and the Decision to Detain a Suspect, 93 YALE L.J. 214 (1983).

330 David A. Harris, Factors for Reasonable Suspicion: When Black and Poor Means Stopped and Frisked, 69 IND. L.J. 659, 678 (1994); see also, e.g., Ronner, supra note 64, at 386 ("African Americans and Hispanics tend to populate poor, inner city neighborhoods, which are commonly known to be high crime areas."); David A. Harris, Particularized Suspicion, Categorical Judgments: Supreme Court Rhetoric Versus Lower Court Reality Under Terry v. Ohio, 72 ST. JoHN's L. REv. 975, 1000-01 (1998) ("Those who live in high crime areas will likely be poor and members of minority groups."); David A. Sklansky, Traffic Stops, Minority Motorists, and the Future of the Fourth Amendment, 1997 SuP. CT. REv. 271, 328 (1997) (noting the disproportionate focus of 
observes:

[t] he insidious effect of such segregation is that the police are able to direct inordinate law enforcement efforts at blacks in the urban core. Also, police officers disproportionally stop, detain, and arrest African Americans. They do this without probable cause and without articulable suspicion. ${ }^{331}$

Just as minorities are more vulnerable to being stopped by police, so, too, are people with few financial resources more vulnerable to government surveillance that falls outside the scope of the Fourth Amendment, requiring no justification at all on the part of the police. ${ }^{332}$ The current definition of a search, as outlined above, requiring of individuals that the measures taken to preserve privacy be virtually insurmountable before police surveillance will be deemed a search, put the poor at a great disadvantage relative to the government and to those with greater resources.

In other words, one's constitutional privacy is limited by one's actual privacy.... [which] leads to the conclusion that Fourth Amendment protection varies depending on the extent to which one can afford accoutrements of wealth such as a freestanding home, fences, lawns, heavy curtains, and vision- and sound-proof doors and walls. ... As a result,

police on minority suspects because "minority neighborhoods tend to be poorer and more crime-ridden").

331 Ronner, supra note 64, at 386-87. Professor Ronner illuminates the repressed racism inherent in Terry v. Ohio, 392 U.S. 1 (1968), discussing how the Court, in permitting stops based on reasonable suspicion of criminal activity, acknowledged, then dismissed, the very real potential of "wholesale harassment" of members of minority communities, something, the Court stated, the exclusionary rule was impotent to prevent or address. Id. at 406-07 (quoting Terry, 319 U.S. at 14). While Terry "laid the foundation for a racist Fourth Amendment," the Court "installed the roof" thirty years later in Illinois $v$. Wardlow, 528 U.S. 119 (2000) (upholding a seizure based on unprovoked flight in a high-crime area). Ronner, supra note 64, at 405. According to Professor Ronner, each of the criteria used by the Court to establish reasonable suspicion in Wardlow targets minorities, in that simple presence in their own community becomes grounds for suspicion (notwithstanding that presence in a non-minority community may also be grounds for suspicion), as does the natural response of flight from police, based on a "well-founded and historically ingrained fear and distrust of law enforcement" (making flight not quite so "unprovoked" as the Court would have us believe), resulting in a "Fourth Amendment [that] cannot serve the very class of people that needs it the most." Id. at 413-23. Professor Tracey Maclin finds it "startling that the Court would ignore racial concerns when formulating constitutional rules that control police discretion to search and seize persons on the street." Maclin, Race and the Fourth Amendment, supra note 329, at 340; see also Carbado, supra note 327, at 965-67 (arguing that the Court either ignores or constructs race in order to reach desired doctrinal outcomes in particular cases).

332 Slobogin, supra note 328 , at 400. 
people who live in public spaces (for instance, the homeless who reside in boxes) and people who have difficulty hiding or distancing their living space from casual observers (for instance, those who live in tenements and other crowded areas) are much more likely to experience unregulated government intrusions. ${ }^{333}$

If Mr. Ciraolo, with his doubly-fenced yard (complete with swimming pool and sunning deck) did not do enough to earn the protection of the Fourth Amendment, how likely is it that the urban poor will be able to do so?

The incongruence between current Fourth Amendment doctrine, with its focus on privacy and precautions, and the reality of daily life for so many of our citizens becomes all the more evident when one considers the following eloquent passage, which, written and delivered by Professor Anthony Amsterdam over thirty years ago, still resonates today:

[The framers] did not know the miles on miles of tiny boxes in which millions of our people live, driven to the streets with all the desperation of a prisoner escaping and then dogged down endless, agitated corridors of windows till the human soul cries out for someplace it can breathe and not be stared at. They did not know the vast, stinking slums of Harlem summers where the people boil like eggs if every door and window is not opened, and where to be young and black and take to the streets is to be hassled by the cops. ${ }^{334}$

It seems that, like the Framers, Supreme Court Justices also cannot contemplate the conditions described above and experienced by so many of our citizens. ${ }^{335}$ When privacy is the ultimate interest protected by the Fourth Amendment's ban against unreasonable

333 Id. at 401.

334 Amsterdam, supra note 41, at 401.

335 For example, as noted by Professor Heffernan, supra note 84, at 85-86, when deciding that overnight guests in homes are entitled to claim the protection of the Fourth Amendment against unreasonable searches, the Justices were able to see themselves as guests in an invaded home: "We stay in others' homes when we travel to a strange city for business or pleasure, when we visit our parents, children, or more distant relatives out of town .... We will all be hosts and we will all be guests many times in our lives." Minnesota v. Olson, 495 U.S. 91, 99 (1989) (emphasis added). However, in concluding that a mobile home was more like an automobile than a home, for purposes of qualifying for the automobile exception to the Fourth Amendment's warrant requirement, "we," the Justices were nowhere to be found. Heffernan, supra note 84, at 85-86 (discussing California v. Carney, 471 U.S. 386 (1985)). 
searches, and at the same time privacy is also the yardstick by which the existence of Fourth Amendment protection is measured, the middle-class homeowner will be better situated than his counterpart living in the tenement: the former can shut his outer doors and retreat into his home to enjoy his solitude and refuge from the outside world.

But if you live in a cheap hotel or in a ghetto flat, your neighbors can hear you breathing quietly even in temperate weather when it is possible to keep the windows and the doors closed. For the tenement dweller, the difference between observation by neighbors and visitors who ordinarily use the common hallways and observation by policemen who come into the hallways to "check up" or "look around" is the difference between all the privacy that his condition allows and none. Is that small difference too unimportant to claim Fourth Amendment protection? ? $^{336}$

Thus, requiring a high level of actual privacy before one is entitled to Fourth Amendment protection further diminishes what little privacy is afforded to those living in conditions of poverty.

Perhaps, as suggested by Professor Yale Kamisar, "few of us have ever seen or thought much about the plight of an individual who is being searched illegally in a poor neighborhood ...."337 If we care about equality, and if we, as a people, believe the guarantees of the constitution should apply to one and all, regardless of the ability to purchase those guarantees, we must care about the very different Fourth Amendment experienced by minorities and the poor.

The reader has already seen this before, of course-a system under which individuals are in effect held responsible for the circumstances thrust upon them or for the consequences of exercising some small bit of personal freedom or autonomy. Recall, in the traditional rape context, how the prevailing attitude was one that punished women for engaging in consensual sexual activity or

336 Amsterdam, supra note 41, at 404.

337 Yale Kamisar, The Warren Court and Criminal Justice: A Quarter-Century Retrospective, 31 TulsA L.J. 1, 43 (1995) (comparing the seeming indifference to unfair search practices with the enthusiastic public reception of the Court's decision in Gideon v. Wainwright, 372 U.S. 335 (1963) (holding that the Sixth Amendment right to counsel is a fundamental right, and that as such, indigent defendants are entitled to appointed counsel)). Professor Kamisar mentions another possible explanation for such disparate public reactions: "Too many people . . . are roused by any violation of 'the symbol of a ceremonial trial,' but 'left unmoved by an ordinary nonceremonial injustice." Kamisar, supra, at 44 (quoting THURMAN W. ARNOLD, THE Symbols OF Government 142 (Harbinger ed., Harcourt, Brace \& World 1962)). 
even for placing themselves in risky situations where they might be victimized. Recall how, according to feminists, the law and practice of rape kept women at home and under control, existing "in a condition of terror" and relying on protection from the very group they needed protecting from. ${ }^{338}$ Similarly, current search doctrine punishes individuals for stepping outside their homes (or failing to adequately secure them) or for interacting with others, making all of us truly "secure" only behind bolted doors and drawn window shades and in nearly complete solitude. And, especially in poor, urban areas, the police take on the dual role of protector and predator as a means of social control. ${ }^{339}$

Further, if rape victims found themselves, rather than their attackers, to be effectively on trial in a rape prosecution, experiencing all the distrust and disapproval inuring to criminal defendants generally, how much greater the disadvantage must be to most victims of police surveillance who seek to claim a Fourth Amendment violation before a court, who find themselves not only effectively, but actually, on trial as criminal defendants. Search doctrine is almost exclusively driven by the Court's response to defendants' claims of violations, with those claims arising, generally, only because something incriminating was found.

In other words, the champions of our Fourth Amendment rights are often factually guilty, and the Court's hesitation to reverse convictions and deprive the State of valuable evidence may well be the true motivation behind the government-friendly doctrine that has developed. However, such a narrow focus on the immediate consequences of a decision bearing on the constitutionality of a police investigative practice misses the larger picture and makes us all

338 See supra notes 208-20 and accompanying text.

339 Professor Ross notes that "there is a culture of masculinity within police departments that places 'an emphasis on demonstrating the aggressive demeanor known as command presence.... A corollary of that attitude is that police officers feel the need to punish disrespect."' Ross, supra note 3, at 26 (quoting Frank Rude Cooper, “Who's the Man?": Masculinities Studies, Terry Stops, and Police Training (Suffolk Univ. L. Sch. Research Paper No. 08-23, 2009), available at http://ssrn.com/abstract=1257183). The Court, in Terry $v$. Ohio, also recognized aggressive policing as a source of friction between law enforcement and minority communities, noting that " $[\mathrm{t}]$ his is particularly true in situations where the "stop and frisk' of youths or minority group members is 'motivated by the officers' perceived need to maintain the power image of the beat officer, an aim sometimes accomplished by humiliating anyone who attempts to undermine police control of the streets."' Terry v. Ohio, 392 U.S. 1, 14-15 n.11 (1967) (quoting PRESIDENT'S COMMISSION ON LAW ENFORCEMENT AND ADMINISTRATION OF JUSTICE, TASK ForCE REPORT: THE POLICE 183 (1967)). 
more vulnerable and less secure. ${ }^{340}$ Whether fueled by animus towards the exclusionary rule and a reluctance to overturn convictions or by a categorical preference for the interests of law enforcement, an overwhelming number of the Court's Fourth Amendment decisions have favored the government. ${ }^{341}$

Professor Tracey Maclin describes the Court's post-Katz jurisprudence as abandoning that case's "individualistic, protectionoriented approach" in favor of an approach weighing individual interests of freedom from government intrusions against the government's interest in law enforcement, with the Court's balancing approach eventually morphing into a "'police perspective' approach." ${ }^{342}$ In determining whether individuals possess a legitimate or reasonable expectation of privacy, then, the Court adopts the perspective of the "government agent seeking to destroy that privacy. ... In effect, the Court has adopted the outlook of the fox in defining the rules that will govern the henhouse." ${ }^{343}$ This, of course, turns the Fourth Amendment on its head and destroys the intent of Katz, in so much as that case reflected an understanding of the Fourth Amendment as a provision meant to protect the citizenry against the excesses and arbitrary exercise of official power, and not a provision meant to aid the government in the enforcement of its laws. ${ }^{344}$

A Court wishing to craft a government-friendly Fourth Amendment doctrine has three tools at its disposal: it can recognize police activity as implicating the Fourth Amendment, but determine it to be reasonable; it can acknowledge a Fourth Amendment violation but uphold convictions obtained with illegally obtained evidence by limiting the reach of the exclusionary remedy; or it can simply hold that the police conduct at issue simply does not trigger the Fourth Amendment at all. This Article, of course, is concerned with the third method of ensuring a favorable Fourth Amendment landscape for law enforcement. However, all three doctrinal

\footnotetext{
340 See Maclin, Government Perspective, supra note 95, at 669-70 ("[T] he Court is often unable (or unwilling) to appreciate the implications of its rulings for persons not immediately involved in the cases before it ... whenever the Court upholds a challenged police practice against an obviously guilty individual, the Court is also licensing similar intrusions against not-so-obviously innocent persons as well.").

${ }_{341}$ Silas J. Wasserstrom, The Incredible Shrinking Fourth Amendment, 21 AM. CRIM. L. REV. 257 (1984).

342 Maclin, Government Perspective, supra note 95, at 669-70.

$343 \quad I d$. at $674-75$.

344 See id. at $677-78$.
} 
approaches achieve the same practical result for the government: broad access to individuals despite the Amendment's purpose to limit such access. The reader may recall that rape law scholars described traditional rape law in similar terms: despite the offense of rape purporting to limit men's access to women, the law, as construed, accomplished quite the opposite. ${ }^{345}$

The reader should also here recall the Article's discussion, in Part III.B, of some of the broader concerns that fueled the reforms achieved in the law of rape. Rape reformers sought to address the imbalance of power that skewed doctrine in favor of men as the advantaged group, and which resulted in a law that did little to improve male behavior and much to burden women both in their individual and collective capacities. While male sexual autonomy was valued and promoted, the autonomy of women was not only discouraged but, in effect, punished. The same broad criticisms are mirrored in Fourth Amendment search doctrine. The Court's jurisprudence promotes, and thus enhances, the imbalance of power between government and individual, resulting in search law that provides law enforcement expansive investigatory freedom (autonomy) with little or no restrictions on its behavior. Not only do the victims of intrusive police surveillance find themselves at a severe individual disadvantage, but entire groups of citizens are disproportionately burdened, namely minorities and the poor. Individual autonomy, as in the rape context, is discouraged and punished, and victims are blamed for their failure to secure themselves against intrusion if they have in any way placed themselves at risk. Thus the broader goals of rape reformers- to promote equality by addressing the imbalance of power, to improve behavior, and to promote autonomy-are applicable to this context as well. The next section completes the analogy between these two areas of law by turning again to the specific reforms achieved in and proposed to the law of rape as they inform the pursuit of the above-mentioned goals in the law of searches.

\section{Search Law Tomorrow: What We Can Learn from Rape Reform}

\section{Abolishing the Utmost Resistance Requirement}

One of the most significant reforms (and victories) achieved by rape reformers was the abolition of the utmost resistance requirement. A parallel change in the law of searches is warranted

\footnotetext{
345 See supra text accompanying notes 189-190.
} 
and adequately supported by Katz. The Fourth Amendment described above, with what effectively amounts to an utmost resistance requirement, ${ }^{346}$ excludes too many from its protective reach. While Katz does not, in this author's view, require an abolition of any resistance requirement, it can be understood to support a requirement of reasonable resistance. After all, Mr. Katz did resist the aural intrusion perpetrated on him by "occup[ying] [the phone booth], shut[ting] the door behind him, and pay[ing] the toll . . .."347 Further, the Katz majority's mention of what one "seeks to preserve as private" ${ }^{348}$ implies some action on the part of the individual to exclude others.

The question of how much is required of individuals can and should be understood in terms of reasonableness, as described in various formulations of the reasonable resistance requirement in rape law, with resistance serving two functions: to demonstrate that the force used by police to overcome that resistance is sufficient force to constitute a Fourth Amendment search and to demonstrate the victim's nonconsent. In the rape context, the Missouri Court of Appeals, for example, engaged in a totality-of-circumstances analysis, taking into account the ages of victim and perpetrator, any relative advantage the perpetrator could exploit, and the setting of the attack. ${ }^{349}$ In other words, the force used by the perpetrator was measured not by an ideal standard of utmost resistance, but by the more realistic standard of the victim's capabilities and ability to resist under the circumstances. As for the second function of resistance, serving as a demonstration of nonconsent, reasonable resistance has been defined as what was reasonably needed to inform the perpetrator of the victim's lack of consent, without requiring the victim to resist to the utmost before the perpetrator would be obligated to take her "no" seriously. ${ }^{350}$ Similarly, police surveillance should be deemed a search when police overcome reasonable measures taken by the victim to maintain privacy, basing a finding of reasonableness on a realistic assessment of a given victim's capability to resist the police and not requiring of the victim more than practicably or economically possible, taking into account the imbalance of strength and power between government and victim.

346 See supra text accompanying notes 289-299.

347 Katz v. United States, 389 U.S. 347, 352 (1967).

$348 I d$. at 351.

349 See State v. Kilmartin, 904 S.W.2d 370, 374 (Mo. Ct. App. 1995).

350 See, e.g., Del. CRIM. Code $\$ 761$ (j) (1) (2011). 
Finally, traditional rape law evolved to recognize as rape when the perpetrator, through deception, intoxicants, threats, or other means, prevented resistance by the victim. In the search context, deception and secrecy are police tools of the trade. Obviously, true consent searches aside, police would acquire considerably less information if they announced their surveillance to suspects. This surreptitious nature of surveillance is troubling, however, when the definition of a search requires such vigorous resistance on the part of the victim, as most often the victim has no idea that extraordinary precautions are even needed.

Of particular concern is the use of undercover agents and informants, described by Professor Albert Alschuler as a "dark corner of law enforcement that is all but immune from judicial control," ${ }^{551}$ whereby police, whether by posing as drug buyers or meter readers, or worse yet, by manipulating relationships (either artificially creating new or maliciously destroying existing friendships) deceive individuals into permitting access into their homes and lives. As far as the use of "false friends," the Court justifies this unregulated form of surveillance on the theory that the target has assumed the risk that her relationships might not be as she believes them to be.

Pointing out again the de facto resistance requirement permeating the reasonable-expectation-of-privacy test, what if the government does more than deceive the victim into letting her guard down, and takes affirmative steps to thwart the victim's ability to resist? In 1994, to accommodate the FBI's concern over new telephone technologies that would hamper the government's ability to listen in on our conversations, Congress enacted the Communications Assistance for Law Enforcement Act (CALEA). ${ }^{352}$ Professor Lee Tien offers the following description:

CALEA in effect mandates that telecommunications be designed to facilitate government surveillance .... Under CALEA, "carriers must take steps to ensure that the broad technological trends in the industry do not eliminate law enforcement access to communications of targeted individuals".... For instance, carriers subject to CALEA cannot provide carrier-based encryption services without assuring that law enforcement can decrypt the

${ }^{351}$ Albert W. Alschuler, Interpersonal Privacy and the Fourth Amendment, 4 N. ILL. U. L. REV. 1, 38 (1983).

352 Communications Assistance for Law Enforcement Act (CALEA), Pub. L. No. 103-414, 108 Stat. 4279 (1994) (codified as 47 U.S.C. $§ \S 1101-1010$ (2000) and in portions throughout Title 18). 
communications. ${ }^{353}$

With such measures implemented to facilitate governmental intrusion into our communications, the government is having its cake and eating it, too. As long as the reasonableness of an expectation of privacy depends on the victim's precautions to maintain that privacy (precautions, as we have seen, that must be all but impervious to penetration), the government effectively destroys any reasonable expectation by rendering resistance impossible. Making matters even worse, victims are lulled into a false sense of security in their communications because they may believe that they have in fact taken precautions (or that such precautions are already in place), and that their conversations are protected from outside interference.

This very real method of eliminating reasonable expectations of privacy is far more dangerous to personal security than the hypothetical posed by Justice Blackmun in his opinion for the Court in Smith v. Maryland, contemplating the Government's sudden announcement, on "nationwide television that all homes henceforth would be subject to warrantless entry," which would, naturally, eviscerate any "actual expectation of privacy regarding [our] homes, papers, and effects." ${ }^{\text {"354 }}$ In Justice Blackmun's totalitarian world, at least, citizens would be on notice of the government's surveillance activities, and could prepare accordingly. ${ }^{355}$ For purposes of defining the search, then, resistance should not be required where the government has taken affirmative steps to preclude the possibility of such resistance, any more than resistance is expected from the victim of date rape when she has unknowingly been given an intoxicant that renders her incapable of resisting.

353 Lee Tien, Doors, Envelopes, and Encryption: The Uncertain Role of Precautions in Fourth Amendment Law, 54 DePaul L. Rev. 873, 905 (2005) (quoting James X. Dempsey, Communications Privacy in the Digital Age: Revitalizing the Federal Wiretap Laws to Enhance Privacy, 8 ALB. L.J. SCI. \& TECH. 65, 90 (1997) (arguing that the government should not be constitutionally permitted to secretly interfere with the ability to take precautions against surveillance)).

354 Smith v. Maryland, 442 U.S. 735 n.5 (1979).

355 See also Tien, supra note 353, at 888 (“[W]e are unlikely to take precautions if we are not aware that our privacy is threatened. If the government installs highly conspicuous video surveillance cameras in some public places, people who do not like to be photographed might avoid those places. They would have no reason to avoid those places if the cameras were hidden."). 


\section{Recalibrating Force and Nonconsent}

Many of the advances in rape law were driven by the twin goals of improving male behavior and promoting women's autonomy. Recast in Fourth Amendment terms, these goals resonate with those urging change in criminal procedure doctrine as well and are consistent with the purpose of that Amendment (and others): to cabin official power and promote individual liberty and freedom. However, the Court's deference to the needs of law enforcement over individual interests has fostered the opposite result, and the government's ability to intrude upon its citizens, often with no justification whatsoever, has been greatly augmented. Numerous scholars have reached the conclusion that the Court's privacycentered approach has failed to deliver the "security" promised to the "people."

What does it mean to be secure? Professor Thomas Clancy, for example, answers that question by equating the right to be secure with the right to exclude. ${ }^{357}$ Moreover, the right to exclude does not require justification based on the pursuit of other aims, although the assertion of that right may be motivated by a desire to enjoy property, to maintain privacy, to preserve dignity, or even simply to express anti-government sentiment. ${ }^{358}$ The Fourth Amendment right to be secure may also be understood as an interest in exercising some level of control over one's person, house, papers, and effects-in other words, as the right to autonomy and self-determination.

What of property and privacy, respectively representing the preKatz and post-Katz regimes, as the primary measures of the Fourth Amendment's scope? Professor Halliburton proposes that the Fourth Amendment be reunited with its property-based roots, but urges that

See generally Clancy, supra note 83 , at 307-08 ("Only by understanding the meaning of the term 'secure' is it possible to determine the scope of the Fourth Amendment's protections ...."); Halliburton, How Privacy Killed Katz, supra note 76, at 814 (arguing for a reinvigorated view of "property of personhood" to replace privacy as the primary interest protected by the Fourth Amendment); William J. Stuntz, Privacy's Problem and the Law of Criminal Procedure, 93 Mich. L. Rev. 1016 (1995) (arguing that criminal procedure should focus less on privacy and more on police coercion); Tomkovicz, supra note 79 (promoting an instrumental view of Fourth Amendment privacy).

357 Clancy, supra note 83, at 308-09. Professor Clancy identifies property, privacy, and security as the three "possible candidates" for delineating the scope of Fourth Amendment protection, arguing that property and privacy have proved inadequate measures of the Amendment's protection, and that security, as the right to exclude, is the interest best suited to the task. See id.

$358 \quad I d$. at 309. 
property be broadly understood in terms of its connection to and enrichment of personhood. ${ }^{359}$ Professor Halliburton draws upon the work of Professor Margaret Radin in exploring the "relationship between the law of property and what she calls the "personhood perspective'.... The core 'premise underlying the personhood perspective is that to achieve proper self development-to be a person-an individual needs some control over resources in the external environment." ${ }^{360}$

Professor James Tomkovicz, on the other hand, urges an instrumental understanding of privacy as the core value to be protected by the Fourth Amendment, which includes, but is not limited to, a view of privacy as promoting secrecy for the sake of secrecy alone. ${ }^{361}$ An instrumental conception of privacy promotes a great deal more than secrecy, and perhaps was given its most eloquent and concise expression by Warren and Brandeis, who described Fourth Amendment privacy as "the right to be let alone." ${ }^{362}$ When we are afforded privacy, or let alone, we are given the space and freedom to constitute ourselves as individuals, and privacy can realize its function "as a medium within which other rights and interests can survive, even flourish." ${ }^{363}$ While confidentiality and solitude at times provide the necessary shelter from the world in which we can freely be ourselves, at other times, "a degree of openness is essential to and integrally connected with the exercise and

359 Halliburton, How Privacy Killed Katz, supra note 76, at 851.

360 Id. at 852 (quoting Margaret Jane Radin, Property and Personhood, 34 STAN. L. REV. 957 (1982)).

361 Tomkovicz, supra note 79, at 648. The Court's conception of privacy as protecting only, or primarily, secrecy, not only has affected the substantive Fourth Amendment right, but has also affected the availability of its primary remedyexclusion. The Court's narrow conception of Fourth Amendment privacy is evidenced by its reasoning that once privacy has been breached it cannot be restored, and therefore, exclusion is not a personal constitutional remedy, but a method of deterring future Fourth Amendment violations. See United States v. Leon, 468 U.S. 897, 906 (1984) (establishing the good-faith exception to the exclusionary rule) (" $[\mathrm{T}]$ he exclusionary rule is neither intended nor able to "cure the invasion of the defendant's rights which he has already suffered.") (quoting Stone v. Powell, 428 U.S. 465, 540 (1976) (White, J., dissenting)); see also United States v. Calandra, 414 U.S. 338, 354 (1974) (holding that the exclusionary rule is inapplicable to grand jury proceedings) ("Th[e] wrong ... is fully accomplished by the original search without probable cause... Questions based on illegally obtained evidence are only a derivative use of the product of a past unlawful search and seizure. They work no new Fourth Amendment wrong."). Id.

${ }^{362}$ Samuel Warren \& Louis Brandeis, The Right to Privacy, 4 HaRv. L. REv. 193, 193 (1890).

T63 Tomkovicz, supra note 79 , at 667 . 
enjoyment of constitutional rights." ${ }^{364}$ Thus, current search doctrine, which penalizes, by removing from the definition of a search, virtually anything we share with others (even inadvertently), forces an impermissible choice between constitutional protections: we exercise associational and expressional freedoms at the cost of our Fourth Amendment rights.

Whether the core interest to be protected by the Fourth Amendment is identified as security, property-as-personhood, instrumental privacy, autonomy, or simply the "right to be let alone," we can once again turn to rape law scholarship for insight. Professor Schulhofer, in urging that autonomy, as something more than simply freedom from violence, should become the focal point for reform, identifies two dimensions of autonomy: physical autonomy, meaning a right to bodily integrity, and moral or intellectual autonomy, involving the capacity to express one's personal preferences. ${ }^{365}$ Understood this way, autonomy is as much about the "right to be let alone" as it is about the right to choose not to be let alone, and to define the scope of our involvement and interactions with others. Therefore, any use of force that interferes with an individual's unconstrained choice with respect to her physical or intellectual preferences is destructive to autonomy.

As for the dual requirement of force and nonconsent, while many rape reformers advocate for the abolition of one or the other, the two elements may not be so easily severable. Maintaining that a search requires, as its elements, both the victim's nonconsent and the government's use of force to overcome that nonconsent, the Court's conceptions of what constitutes sufficient force and what amounts to consent or nonconsent must be reevaluated in light of a more realistic account of social attitudes and norms.

Those rape law scholars advocating for the law to criminalize the use of force to obtain intercourse without regard to the victim's state of mind criticize traditional victim-centered law on two grounds: (1) they are troubled by the law's almost exclusive focus on the victim's conduct and seek to shift attention to the perpetrator and his

\footnotetext{
${ }^{364} I d$. at 682. In advocating for an instrumental conception of privacy, Professor Tomkovicz argues that the reasonable-expectation-of-privacy test should be abandoned in favor of an approach that examines not one's expectations with respect to privacy, but whether the individual claiming a search has a "legitimate need[] for privacy." $I d$. at 700 n.216. "In other words, a qualifying privacy need must have a basis in the laws, principles, traditions, or customs of the American social order ...." Id. at 700 .

365 See Schulhofer, supra note 243, at 71.
} 
conduct, and (2) they are skeptical about the law's reliance on nonconsent as the touchstone of rape, when much behavior that is construed as consent is obtained under conditions of physical, economic, and political inequality. ${ }^{366}$ Thus, rape victims are essentially blamed for the violations of their person, and their passivity, ambiguity, weak resistance, or acquiescence, even under illegitimate pressures, is construed as consent.

The current definition of a search suffers from the same flaws: the Court fixes its attention almost exclusively on the individual claiming a violation when determining whether the victim enjoyed a reasonable expectation of privacy. But this unilateral approach fails to ascertain from what or whom the individual should expect privacy and constructs privacy in a normative vacuum. In other words, the part of the reasonable-expectation-of-privacy test that should give normative content to what citizens have a right to expect from their government is simply missing. This focus on the adequacy (or inadequacy, as is most often the case) of the victim's precautions against the possibility of intrusion has resulted in what Professor Heffernan describes as a "vigilance model of privacy, one that requires people to be constantly alert to the way in which others can intrude on their lives. ${ }^{" 67}$ This model of privacy requires that people remain on high alert to expect the worst from their fellow citizens and, consequently, from the police. Under this model, a failure to guard against having those low expectations met results in a divestiture of Fourth Amendment protection. ${ }^{368}$

Professor Heffernan argues that, instead, Fourth Amendment privacy should be based on an "expectation of forbearance on the part of others-that is, in an expectation that others will restrain their curiosity with respect to those aspects of life that are essential to defining and maintaining individual identity." 369 A forbearance model of privacy is imbued with a strong equality ideal, in that the prevailing expectation is that others will not exploit vulnerability or take advantage of relative positions of superior strength and resources, allowing individuals some measure of personal security regardless of their economic means. In the words of William Pitt to

366 See supra text accompanying notes 233-234.

367 Heffernan, supra note 84 , at 6 .

368 Of course, living in a constant state of vigilance precludes us from experiencing the security and ease that allow us the time and peace of mind to engage in other more personally and socially valuable pursuits.

Id. See also Tien, supra note 353, at 884 (discussing social precautions). 
the House of Commons, words that still resonate today:

The poorest man may, in his cottage, bid defiance to all the forces of the Crown. It may be frail; its roof may shake; the wind may blow through it; the storm may enter; the rain may enter; but the king of England may not enter; all his force dares not cross the threshold of the ruined tenement. ${ }^{370}$

Pitt's powerful words are really as much about affording even the "poorest man" security in his home as they are about physical trespass, although he could not have known when those words were uttered that, over two hundred years later, police could (and would) hover in helicopters over that tenement, their prying eyes entering through cracks in the frail roof alongside the wind and rain. I join Professor Heffernan in advocating that the Court adopt a forbearance model of privacy, and in doing so, give meaningful review to the means used by police to breach that privacy, because when the Fourth Amendment is said to permit the government's violation of ordinary social and legal norms, none of us can claim the security promised to us by that Amendment. ${ }^{37}$

Turning to nonconsent, those rape law scholars, on the other hand, who advocate for a definition of rape that focuses on the victim's consent or nonconsent, seek to elevate autonomy to a position of primary importance in the movement for reform. ${ }^{372}$ For

370 Nelson B. LASSON, History AND DeVElopment of THE FOURTH AMENDMENT to THE CONSTitution OF THE United States 49-50 (1937) (quoted in Heffernan, supra note 84 , at $14-15$ ).

371 Professor Scott Sundby proposes that "government-citizen trust" should be an animating principle in the formation of Fourth Amendment doctrine and values. Scott E. Sundby, "Everyman"'s Fourth Amendment: Privacy or Mutual Trust Between Government and Citizen?, 94 Colum. L. REv. 1751, 1754 (1994). Under this view, which is consistent with the forbearance model described above, citizens should be entitled to trust that the government will refrain from abusing its power, as the government should trust that its citizens are obeying the laws. Id. at 1777-78 (emphasizing the importance of the trust being reciprocal). For Professor Sundby, where government action is inconsistent with the assumption that citizens are acting lawfully, such action should be deemed a search. Id. at 1791. This position is counter to the Court's current approach, which seems to permit the government to assume individual wrongdoing, and subsequently allows governmental measures to verify that assumption, while requiring the public to trust that the government will not intrude unreasonably. Id. at 1811. I submit that the Court's current model defining searches is based on a vigilance model, under which police assume citizen wrongdoing; and citizens, in order to gain Fourth Amendment protection, must also assume that anyone, including government agents, may (and often do) resort to unlawful or socially unacceptable means to violate privacy, and must protect themselves accordingly.

372 See supra text accompanying note 235. 
these scholars, an exclusive focus on force fails to take into account non-forcible methods of violating bodily integrity, such as deception, fraud, extortion, or other coercive abuses of power that interfere with the victim's meaningful choice. Further, an autonomy-based approach recognizes that autonomy involves more than a negative interest in preventing unwanted intercourse, but also includes the positive interest in permitting and engaging in desired intercourse. If we now consider the word "intercourse" outside of its sexual context, the preceding statement applies equally to an autonomybased conception of the Fourth Amendment.

Of course, in constructing its search doctrine, the Court does give almost exclusive attention to the element of consent, but certainly not with the aim of promoting individual autonomy. The Court, rather, construes consent broadly, equating limited consent with knowing exposure, and simultaneously undervalues or completely disregards expressions of nonconsent. Whether described as instrumental privacy or security, the interest of autonomy, in both its negative and positive aspects, and in both its physical and intellectual capacities, should be given more prominence in defining the search. And if autonomy is to be taken seriously, then consent must be defined more narrowly and any expression of the victim's nonconsent must be given credit.

One more reform achieved on behalf of rape victims merits particular attention for its applicability to the law of searches: the enactment of "rape-shield" laws. Prior to the enactment of these evidentiary provisions, rape victims were essentially put on trial, with their past sexual history, their attire, and their sexual behavior regularly paraded in front of juries to prove both propensity to lie and propensity to engage in sexual intercourse. ${ }^{373}$ Noting again the positive expression of autonomy, permitting women to choose when to engage in sexual activity, as well as when not to, rape-shield statutes sought to prevent juries from punishing women who voluntarily engaged in intercourse (or appeared as if they wanted to) by finding, as a matter of fact, that a woman who would consent to one would likely consent to all.

This reasoning is, of course, precisely the logic underlying the Court's treatment of voluntary disclosure to third parties as knowing exposure to the public. As long as privacy-as-secrecy is treated as the primary interest protected by the Fourth Amendment, the individual,

See supra text accompanying notes 173-176. 
in disclosing information to anyone, has relinquished his privacy in an absolute sense, and therefore has forfeited any reasonable expectation of privacy. Again, a shift in focus to a broad autonomybased model of Fourth Amendment protection would respect and permit an individual's choice to share certain information in a limited way (which, in today's world, is often not really any choice at all), without equating that choice with a complete forfeiture of Fourth Amendment protection.

3. A Balanced Approach to the Katz ReasonableExpectation-of-Privacy Test

Drawing from rape law and analogizing to Fourth Amendment search law, this Article has identified the similar broad goals of improving the behavior of those in power, encouraging autonomy of the subjugated group, and promoting equality. The realization of these goals in the context of defining a search can be assisted through the adoption of parallel reforms-namely, expanding the notion of force, narrowing the understanding of consent while recognizing nonconsent expansively, and lowering the resistance requirement to a reasonable level. This Article next turns to situating these reforms within the framework provided by Katz $v$. United States. ${ }^{374}$ Part II of the Article has presented support for this balanced, conduct-oriented approach in the text of Katz, examining Justice Harlan's concurring opinion, from which the Court has derived the current reasonable expectation of privacy definition of a search, in conjunction with Justice Stewart's opinion for the majority. A careful reading of these opinions will demonstrate that the reforms suggested above provide a model of defining the Fourth Amendment search that is truer to the letter and spirit of Katz than the Court's current approach.

Justice Harlan's definition of a search requires "first that a person have exhibited an actual (subjective) expectation of privacy, and, second, that the expectation be one that society is prepared to recognize as "reasonable." "375 Thus, once a person has exhibited, through physical or social cues, ${ }^{376}$ that he subjectively wishes to keep

374 Katz v. United States, 389 U.S. 347 (1967).

375 Id. at 361 (Harlan, J., concurring).

376 See Tien, supra note 353, at 883-84. While physical precautions, such as fences, doors, window blinds, and luggage, block visual or aural access to information, social precautions entail reliance on the observance of social norms. For example, when one enters a bathroom stall or changing room and closes the door, one expects that others will not peep through cracks, or from above or below 
something private, the first prong of Justice Harlan's test has been met, whether or not those wishes are ultimately respected by the police. Perhaps it was Justice Harlan's use of the word "expectation" that led the Court down an empirical (and quite cynical), rather than normative, path in defining searches, leading to the conclusion, based on rather low expectations of human behavior, that we cannot reasonably expect much from anyone, let alone the police.

Justice Stewart's opinion for the Court, however, contemplates "what [one] seeks to preserve as private," ${ }^{, 77}$ without reference to any expectation regarding his subjective intent. If our expectations, however, are viewed from the perspective of the forbearance model proposed by Professor Heffernan, ${ }^{378}$ then we can legitimately expect that others will respect our wishes to keep certain aspects of our lives private. On the other hand, "[w] hat a person knowingly exposes to the public... is not a subject of Fourth Amendment protection.."379 Thus, the first prong of Justice Harlan's formulation, based on Justice Stewart's language, is all about consent. By seeking to preserve something as private and by exhibiting that subjective intent, an individual demonstrates her nonconsent to physical or visual penetration. Knowing exposure, however, may be seen as constituting affirmative consent, described in the rape context as "affirmative and freely-given permission," ${ }^{380}$ which can be expressed through words or actions.

Although Justice Stewart used the word "knowingly" rather than "intentionally" with respect to exposure to the public, knowing exposure can be understood, in conjunction with its opposite state of actively seeking to conceal, as the intentional failure to take any precautions to conceal that which is known to be open to view. ${ }^{381}$

the door, to observe what is commonly understood to be a private activity, even though it is entirely possible (and easy) to do so. See id. The efficacy of social precautions as creating legitimate expectations of privacy, of course, assumes a forbearance model of privacy. See supra text accompanying note 369.

377 Katz, 389 U.S. at 351 (emphasis added).

378 See supra text accompanying notes 369-370.

379 Katz, 389 U.S. at 351 (emphasis added). Note that Justice Stewart talks about knowingly exposing something to the public, and not the type of limited exposure to third parties that the Court subsequently has equated with knowing exposure.

${ }_{380}$ State in re M.T.S., 129 N.J. 422, 444 (1992).

381 At common law, the definition of "intent" included the mental state of knowledge that the proscribed result was practically certain to occur. See DressLer, UNDERSTANDING CRIMINAL LAW, supra note 27, § 10.04. Therefore, there is support for equating knowledge that exposure is a virtual certainty with intentional exposure. While I may err on the side of a more protective definition of a search by equating knowledge with intent with respect to exposure, the Court has erred in the opposite 
Borrowing once again from an affirmative consent model of rape, in State of New Jersey in re M.T.S., the New Jersey Supreme Court defined physical force as "any amount of force against another person in the absence of what a reasonable person would believe to be affirmative and freely-given permission ...." ${ }^{382}$ Similarly, this Article argues that any measures taken by police in the face of the victim's exhibited nonconsent constitute force, thus avoiding the paradox identified by Professor Estrich in her criticism of State v. Alston: that unwanted penetration can be simultaneously against the will of the victim, and yet not accomplished by force. ${ }^{383}$ On the other hand, what has been knowingly or intentionally exposed to the public requires no force to be seen, and the police are situated similarly to any member of the public.

The second prong of Justice Harlan's test is implicated when the individual seeking privacy has indicated his intent through certain cues and precautions, and the police have used force to overcome those precautions. This Article proposes that this prong, under which the reasonableness of privacy expectations is determined, be infused with the normative values and judgments described above. Once the victim of the surveillance has met the threshold of the first prong, by exhibiting some desire to maintain privacy, courts should realistically evaluate the adequacy of the precautions taken. To that end, this Article advocates for a reasonable resistance approach, with the reasonableness of one's resistance or precautions, as well as the reasonableness of the force used to defeat those precautions, analyzed under the totality of the circumstances.

The circumstances examined would include an honest assessment of the feasibility and availability, to that particular individual, of additional or more effective precautions, not requiring more resistance than realistically possible in her situation. Such a fact-sensitive, case-by-case analysis may be more difficult to administer, and may hamper the creation of bright-line categories of searches and non-searches, but is nevertheless preferable to the one-

direction, essentially equating knowledge with recklessness or negligence. See Colb, supra note 84, at 122 ("[The Court] treats the risk of exposure to third-party wrongdoing as tantamount to an invitation for that exposure ....").

${ }^{382}$ M.T.S., 129 N.J. at 444. Note that the New Jersey Supreme Court provided for a reasonable mistake-of-fact defense, an approach that may be appropriate in the search context as well, for it is difficult to maintain that police are acting improperly if they in fact reasonably believe, from the circumstances, that the subject of the search has consented. See id.

S83 Estrich, supra note 28, at 1111. 
size-fits-all approach the Court has adopted, especially when the "all" are generally wealthy, white individuals who have greater access to effective precautions and are less often the victims of police targeting in the first place.

Any force, then, used to overcome what have been determined to be reasonable precautions, would be a sufficient amount of force to trigger Fourth Amendment protection, and the circumstances taken into account when evaluating the use of force would certainly include inquiry into police violations of social and legal norms, as those norms are intimately tied to the precautions people generally feel the need to take. An assessment of the reasonableness of force, in its relationship to resistance, should also include a conception of force as measures taken to prevent or nullify the efficacy of resistance, including deception, coercion, or the use of certain technology.

\section{Minnesota v. Carter: The Road Not Taken}

Justice Breyer's concurring opinion in Minnesota v. Carter $^{384}$ provides an example of the type of nuanced, fact-sensitive inquiry that a balanced, conduct-oriented approach to defining a search would entail, and demonstrates that courts are eminently capable of conducting such an inquiry in this context. ${ }^{385}$ Carter held that defendants, who were observed by police through a gap in closed window blinds, had no legitimate expectation of privacy or "standing" to contest the search of the apartment in which they were bagging cocaine because their only connection to the apartment was of a "purely commercial nature" and they had spent only a short amount of time therein. ${ }^{386}$ Justice Breyer concurred in the result, but not on "standing" grounds. Rather, Justice Breyer determined that no search had occurred, even had the defendant been the homeowner,

${ }^{384}$ Minnesota v. Carter, 525 U.S. 83 (1998) (holding that defendants had no legitimate expectation of privacy in an apartment they occupied for only a short time, to engage in a purely commercial activity).

385 Indeed, courts regularly engage in totality of the circumstances analysis in a variety of settings, including, for example, in determining whether an individual has been seized, see, e.g., United States v. Mendenhall, 446 U.S. 544, 554 (1980) ("We conclude that a person has been 'seized'... only if, in view of all the circumstances surrounding the incident, a reasonable person would have believed that he was not free to leave."), and, of course, in deciding questions of voluntariness, see, e.g., Schneckloth v. Bustamonte, 412 U.S. 218, 226 (1973) ("In determining whether a defendant's will was overborne in a particular case, the Court has assessed the totality of all the surrounding circumstances ....").

${ }^{386}$ Carter, 525 U.S. at 91. 
based on an analysis of resistance and force such as this Article has outlined. $^{387}$

Acting on a tip from an individual who, while walking past a basement-level window, had observed a group of people bagging cocaine in a garden apartment, Officer Thielen walked within twelve to eighteen inches of the window in question and observed the described criminal behavior through venetian blinds. ${ }^{388}$ To Justice Breyer, whether the blinds had holes or had been simply adjusted in the wrong direction was irrelevant, because "[o]ne who lives in a basement apartment that fronts a publicly traveled street, or similar space, ordinarily understands the need for care lest a member of the public simply direct his gaze downward." ${ }^{389}$ In other words, the defendant did not exercise reasonable resistance under the circumstances, and nothing more would have been required of him than to take care that the blinds were correctly drawn. ${ }^{390}$ It is also relevant that the area from which the activities inside the apartment were observed was not just a public thoroughfare, over which people passed by quickly, but a grassy area where families congregated to walk and play, and where people commonly stored bicycles, ${ }^{391}$ thus increasing the risk of observation by the public. Thus, for Justice Breyer, Officer Thielen observed no more than any member of the public could have, and indeed, had already, observed.

If the defendant's resistance was not sufficient, what of the force used by Officer Thielen? Interestingly, the Minnesota Supreme Court had reached the opposite conclusion, determining that "Officer Thielen had engaged in unusual activity, that he "climbed over some bushes, crouched down and placed his face 12 to 18 inches from the window,' and... saw into the apartment through 'a small gap' in blinds that were drawn." ${ }^{\text {392 }}$ Justice Breyer found that the record did not support these factual assertions, and thus, did not take note of these particular facts in making his determination. ${ }^{393}$ What is most interesting, however, is that Justice Breyer implied that, had the

387 Id. at 103-06 (Breyer, J., concurring).

388 Id. at 103.

389 Id. at 105.

390 The first prong of Justice Harlan's test would have been met, as by drawing the blinds, even though not perfectly, the defendant did indicate a desire to maintain privacy in the apartment, and cannot be said to have knowingly exposed his activities.

391 Carter, 525 U.S. at 103 (Breyer, J., concurring).

392 Id. at 104-05 (Breyer, J., concurring).

393 Id. at 105 (Breyer, J., concurring) ("I would not determine the constitutional significance of factual assertions that the record denies."). 
record permitted him to consider these facts, it may have made a difference. Thus, Justice Breyer allowed for the possibility that, had Officer Thielen climbed over hedges and crouched down, behavior that is clearly contrary to social norms, rather than merely standing in a common area and directing his gaze downward, this distinction may have had constitutional significance. ${ }^{394}$ In any case, Justice Breyer's opinion demonstrates that courts are capable of careful application of specific facts, and indeed, he underscored "the importance of factual nuance in this area of constitutional law . . . ."395

\section{CONCLUSION}

This Article concludes by reiterating the value of exploring the parallel between rape law and search law, and of applying the insights of rape law reform to the law of searches. Space constraints do not permit a thorough exploration of how the proposed changes to the current definition of the Fourth Amendment search would affect existing examples of search doctrine, other than to mention the obviously likely result of the inclusion of more governmental surveillance into the protective reach of the Amendment. The most significant benefit of comparing these two seemingly unrelated areas of law, however, may simply be to promote a shift in perception by engaging the analogy provided by rape law reform. When police surveillance is understood as an exertion of official power over a victim to obtain information for use in "fortify[ing] the coercive power of the state against the individual," ${ }^{396}$ and the subjects of surveillance are seen as potential victims of such exercise of power, then the concerns, goals, and achievements of rape law reformers illuminate the pursuit of balance, equality, dignity, and autonomy in Fourth Amendment doctrine as well.

The time is ripe to advocate for significant change, as the Court, even prior to its decision in United States $v$. Jones, ${ }^{397}$ has indicated its

394 The more unreasonable the measures undertaken by the police, the more reasonable, by inverse proportion, the precautions exercised by the victim seem to be. For example, if Officer Thielen indeed had to climb over bushes to reach an area in which he could crouch in front of the window, then perhaps the drawn blinds, even assuming a small gap, should be considered reasonable as a precaution, as we do not regularly expect people to go through such lengths to look into our homes. In other words, there is a proportional relationship between the reasonableness of precautions and the reasonableness of force used to overcome those precautions.

395 Carter, 525 U.S. at 105 (Breyer, J., concurring).

396 Frank v. Maryland, 359 U.S. 360, 365 (1959).

397 United States v. Jones, 132 S. Ct. 945 (2012). 
willingness to reconsider some of the reasoning that has driven much of its post-Katz jurisprudence. ${ }^{398}$ For example, in Bond $v$. United States, the Court held that the exploratory squeeze of luggage placed in the overhead compartment of a bus was a search, and that the defendant passenger rightfully claimed a reasonable expectation of privacy in his luggage so placed because "he does not expect that other passengers or bus employees will, as a matter of course, feel the bag in an exploratory manner." ${ }^{399}$ The Court adopted a forbearance model of defining a search, and recognized the legitimacy of the defendant's expectation despite the fact that he did not resist to the utmost (he could have kept the luggage under his seat or on his lap), and despite the fact that the police, while clearly violating social norms, did not do anything more than another other passenger could have done. Taking social norms into account both bolstered the adequacy of precautions taken by the defendant, and supported a finding of unreasonable force used to overcome those precautions. ${ }^{400}$

In Kyllo v. United States, the Court held that the use of a thermal imager to detect relative levels of heat escaping from a home constituted a search, as the "Government use[d] a device that is not in general public use, to explore details of a private home that would previously have been unknowable without physical intrusion ...."401 As in Bond, the defendant in Kyllo did not take the most rigorous precautions possible, as he could have insulated his home more thoroughly to conceal the production of excessive heat in his home to the outside world. ${ }^{402}$ The Court's reliance on the fact that the technology used by the police in Kyllo was not in general public use is significant because the Court signaled its understanding that when police resort to extraordinary technological measures to invade privacy, with such means being generally available only to police, individuals fail to successfully resist the intrusion, both because

398 See Colb, supra note 84, at 160-84, for a thorough discussion of numerous cases in which the Court has demonstrated ambivalence concerning the flaws identified by Professor Colb, namely equating vulnerability to exposure with knowing exposure, and equating limited exposure as exposure to the general public.

399 Bond v. United States, 529 U.S. 334, 338-39 (2000).

400 The Court also found significant that the squeeze of the luggage involved a physical, rather than merely visual, inspection. Id. at 337. Of course, this rationale for finding that the government conducted a Fourth Amendment search is entirely consistent with the physical trespass reasoning of Jones with respect to the GPS placed on the defendant's vehicle. See supra note 18 and accompanying text.

401 Kyllo v. United States, 533 U.S. 27, 27 (2001).

402 This fact is noted by Justice Stevens, in dissent. Id. at 45 (Stevens, J., dissenting). 
successful resistance is not feasible in light of the superior technological capability of the police, and because people would not be on notice of the need to resist. In Kyllo, then, the Court adopted a reasonable-resistance approach and demonstrated a broader understanding of force used by government.

Finally, in Ferguson v. City of Charleston, the Court held that the drug testing of the urine of pregnant women, and dissemination of the results to law enforcement for the purpose of forcing those women testing positive into drug treatment, did not qualify as a special needs search. ${ }^{403}$ Because of the procedural posture of the case, the Court did not resolve the question of whether the women had consented to the searches. ${ }^{404}$ By remanding on the issue of consent, the majority seemed at least open to differentiating between knowing exposure, which can be viewed as consent to all, and the informed consent provided to few and limited to a specific purpose. ${ }^{405}$ Thus, by implicitly holding that providing police with the results of the urine testing without specific consent for that purpose constituted a search, the Court indicated its willingness to consider narrowing the scope of consent in the context of defining searches, ${ }^{406}$ which is consistent with the goals of respecting and promoting autonomy identified by rape law and search law scholars alike.

This Article urges criminal procedure scholars to look to the development of current rape law for the insights that may promote similar development in the law of Fourth Amendment searches. At the very least, the specific reforms this Article has identified from rape law and proposes should be considered in defining searchesnamely, adopting a reasonable (rather than utmost) resistance requirement, emphasizing the conduct of police to delineate reasonable expectations of privacy (rather than focusing solely on the victim's conduct), and narrowing the definition of consent-will contribute to the important goals of improving government behavior, promoting individual autonomy and liberty, and realizing the aspiration of equality, both between government and citizen and between wealthy and poor. Most importantly, however, a broader definition of the Fourth Amendment search will ensure that a great

\footnotetext{
403 See Ferguson v. City of Charleston, 532 U.S. 67 (2001).

404 Id. at 67.

405 See id.

406 See id. This is precisely what Justice Sotomayor urges the Court to consider in her concurring opinion in United States v. Jones, 132 S. Ct. 945, 957 (2012)
} (Sotomayor, J., concurring). 
deal more of governmental surveillance will be subject to judicial scrutiny, resulting in a Fourth Amendment that truly protects people, and not police. ${ }^{407}$

${ }^{407}$ This is, of course, a reference to Justice Stewart's famous declaration in Katz: "For the Fourth Amendment protects people, not places." Katz v. United States, 389 U.S. 347, 351 (1967). In closing, I wish to emphasize that a more inclusive definition of a search will not necessarily result in complete inaccessibility of information to law enforcement. By including more surveillance within the scope of the Fourth Amendment, however, police will be required to comply with its substantive and procedural requirements. What those requirements are, or, in other words, what renders searches reasonable under the Fourth Amendment, is a separate, although related, issue. For one approach to the question of balancing a more inclusive definition of a search with law enforcement needs, see Christopher Slobogin, Peeping Techno-Toms and the Fourth Amendment: Seeing Through Kyllo's Rules Governing Technological Surveillance, 86 MINN. L. REv. 1393, 1427-33 (2002) (arguing for a proportionality principle in Fourth Amendment search doctrine, pursuant to which the definition of a search would be expanded to include a great deal more of the government surveillance activity that the current narrow definition excludes, but adjusting the level of justification required for the search according to its level of intrusiveness). 